\title{
Charophytes (Characeae, Charophyta) in the Czech Republic: taxonomy, autecology and distribution
}

\author{
Lenka CAISOVÁ ${ }^{1,2 *} \&$ Maciej GĄBKA ${ }^{3}$ \\ ${ }^{1}$ University of South Bohemia, Faculty of Sciences, Branišovská 31, CZ-370 05 České Budějovice, Czech Republic; \\ * corresponding author, e-mail: lcaisova@gmail.com \\ 'Institute of Botany, Academy of Sciences of the Czech Republic, Dukelská 135, CZ - 37982 Treebon̆, Czech \\ Republic \\ ${ }^{3}$ Adam Mickiewicz University, Faculty of Biology, Department of Hydrobiology, Umultowska 89, PL-61 614 \\ Poznań, Poland
}

\begin{abstract}
The Charales (stoneworts) are an ancient monophyletic group with conserved features same in ancesters as well as in present representatives. They are considered to be closely related to the ancestors of land plants. The taxonomy of Charales was delimitated on the basis of morphology and later by fossil characters as well. Nowadays, the higher taxa are relatively well defined and their delimitation is supported by molecular analyses. However, the situation is more problematic at subgeneric levels. The appearance often depends on the environmental conditions that can produce broad morphological variation. The last report on Charales in Bohemia was a checklist of taxa and their distribution along with ecological requirements (ViLhelm 1914). Although about the research history and the species diversity in Bohemia from the $19^{\text {th }}$ century are well recorded, there is little information from the $18^{\text {th }}$ and $20^{\text {th }}$ centuries. We have compiled here all historical and current data about the distribution of all members of Charales in the Czech Republic along with information on their ecological preferences. This paper presents a list of 26 species of the four genera of charophytes found in waters of the Czech Republic. The species have been distributed in over 1000 localities.
\end{abstract}

Key words: charophytes, Characeae, Chara, Nitella, Tolypella, determination, distribution, taxonomy

\section{Introduction}

The Characeae (Charophyceae, Charophyta), commonly known as stoneworts, are ancient monophyletic group with conserved features in their morphology (GARBARY et al. 1993, MCCOURT et al. 1996, FeIST \& FEIST 1997). The organization of body and life cycle of the Characeae are distinctive (Printz 1927, Dangeard 1933, Irvine \& JoHN 1984), but plants, particularly in the genus Chara Vaillant, have often been mistaken for aquatic phanerogams, especially for underwater horsetail. The species and infraspecific concepts have been delimitated on the basis of vegetative morphology and characteristic oospore wall ornamentations (Wood 1962, LeICHT et al. 1990). Currently the taxonomy of Charales is well supported by molecular analyses (SAKAYAMA et al. 2002, SaKayama 2008).

This paper is presenting main concepts in the taxonomy of charophytes. Based on the data in the literature, two complementary approaches are presented: the first, concerning charophyte morphology and life history and the second, current molecular achievements.

We have compiled all historical and current data about the distribution of localities reported for all members of Characeae in the Czech Republic along with information on their basic ecological preferences.

\section{Fossil evidence}

The resistant walls of oospores, deposited in sediments, allow Charales to be used in the reconstructions of climatic and ecological conditions (Proctor 1975, HaAs 1994, MartínClosas 2003, Zatoń et al. 2005, Hutorowicz 2006). The presence of fossilized oogonia 
(gyrogonites) indicates the origin of this group in the Late Silurian (Grambast 1974, Khan \& SARMA 1984, MeIERS et al. 1999). Landeyran charophytes (deposited near the southern part of the French Massif Central) exemplify the oldest record of heterogamy and bisexuality (FEIST \& FeIsT 1997). The phylogenetic relationships among Paleozoic taxa on the basis of presence and morphology of utricles (ancestral generative organs) were proposed by FeIsT et al. (2005). Some morphological studies of gyrogonites demonstrate that there is a tendency to simplify reproductive organs, e.g. to reduce the number of tube cells and to modify their orientation during the evolution (Grambast 1974, McCourt et al. 1996, Graham \& WiLcox 2000). McCouRT et al. (1996) indicates on the basis of characteristic morphology of fossil Characeae that the tribe Chareae and Nitelleae could be derived from subfamilies Porocharoideae and Stellatocharoideae. On the contrary, FeIsT et al. (2005) regard Eocharaceae as ancestral evolutionary lineage of Characeae. The basal position of the genus Nitella AGARDH in the frame of Charales is supported by the similarity of morphological features with Paleonitella, which is the oldest species of charalean algae (McCourT et al. 1996).

\section{Taxonomic delimitation}

In the $20^{\text {th }}$ century, Charophyta were classified as green algae (Chlorophyta). The investigations of Charophyta by Stewart \& Mattox (1975), based on morphology and comparative cytology, showed that the group of Chlorophyta should be divided into two classes: the Chlorophyceae and Charophyceae. According to their study, the Charophyceae included not only the Charales but also other groups of green algae such as the Zygnematales and Coleochaetales. Nowadays the Charophyta group is referred as the Streptophyta including orders Chlorokybales, Klebsormidiales, Coleochaetales and Charales (Matтox \& STEWART 1984). On the basis of morphological, ultrastructural and molecular analyses, particularly the Charales and Coleochaetales are considered to be closely related to the ancestor of land plants (Grambast 1974, Mishler \& Churchill 1985, Surek et al. 1993, McCourt 1995, Melkonian \& Surek 1995, Martín-Closas 2003). However, their relationships with higher plants have still not been fully resolved (MATTOX \& STEWART 1984,
McCourt et al. 1995). The molecular analyses (18S rRNA, 5S rRNA and Rubisco (rbcL) gene) supported only the position of the Charales as a sister taxon of land plants (Graham 1993, SUREK et al. 1993, McCourt et al. 1996, Karol et al. 2001).

The order Charales contains one family with six genera divided into two tribes Chareae [Chara LinNAEUs, Lamprothamnium J. GRoves, Nitellopsis Hy, Lychnothamnus (RUPR.) LeONHARDI] and Nitelleae [Nitella AGARDH, Tolypella (A. BR.) LEONHARDI]. This system was created on the basis of the morphology (WoOD 1962, WoOD \& IMAHORY 1965) and later supported by analyses of fossil characters, especially by the appearance of fossil gametangia (gyrogonites) (GRAMBAST 1974). Subsequently some authors expressed doubts about the delimitation (validity) of some genera within Characeae, e.g. doubts about the monophyly of the genus Tolypella or about the relationships among Chara, Lamprothamnium and Lychnothamnus (Soulié-Märsche 1989, FeIST \& Grambast-Fessard 1991). According to McCourt et al. (1996) the members of the tribe Chareae form monophyletic group, whereas Nitella and Tolypella do not correspond to the monophyletic tribe Nitelleae. On the basis of the morphology, molecular analyses and chromosome studies Tolypella is a distinct genus (SAWA 1974, SAWA \& Frame 1974, McCourt et al. 1996, Meiers et al. 1999) and although Lychnothamnus is a sister taxon to Nitellopsis, it is not closely related to Chara (McCourT et al. 1996).

More problematic is the classification at lower species level (WOOD \& IMAHORY 1965) mainly considered oospore wall ornamentations to be a crucial diagnostic feature at the species and infraspecific levels. On the basis of morphological similarities, they reclassified many taxa that had been previously accepted as a species to the infraspecific rank. The current studies indicate that some of the infraspecific taxa defined by Wood \& IMAHORY (1965) should be recognized as distinct species (JoHn et al. 1990, MuKHERJEe \& RAY 1993, RAY et al. 2001, MANDAL \& RAY 2004, SAKAYAMA et al. 2006). Although there are a lot of evidence that oospore wall ornamentation in the genus Nitella is a useful guide to species determination, it is not so sufficient taxonomic criterion for species of Chara (John \& Moore 1987, Casanova 1991, Casanova 1997, Sakayama et al. 2002, Abrol \& Bhatnagar 2006, SaKayama et al. 2006, CASAnova 2007). The problem of delimitation at lower taxonomic levels 
should be solved using combination of scanning electron microscopy (SEM) applied on the oospore morphology, general morphology and molecular analyses based on 18S rRNA and Rubisco (rbcL) gene sequences (John \& Moore 1987, SaKayama et al. 2002, Mandal \& Ray 2004, Kapralov \& Filatov 2007, Sakayama 2008).

\section{Diagnostic features}

In spite of modern approaches the morphological features (see in Figs 1-12) still play crucial role in determination of Charales. The two tribes Chareae and Nitelleae are distinguished by the number and arrangement of the coronula cells at the apex of the oogonium. The coronula consists of five cells arranged in one tier in the Chareae, whereas two tiers (each with five cells) are typical for the Nitelleae. The second difference between Chareae and Nitelleae is the construction of rays in the whorls. In the tribe Chareae the main axis supports whorls of simple branchlets at the nodes, in case of Nitelleae the whorls are made up of rays which may be simple or divided. Another distinguishing feature for Chareae and Nitelleae

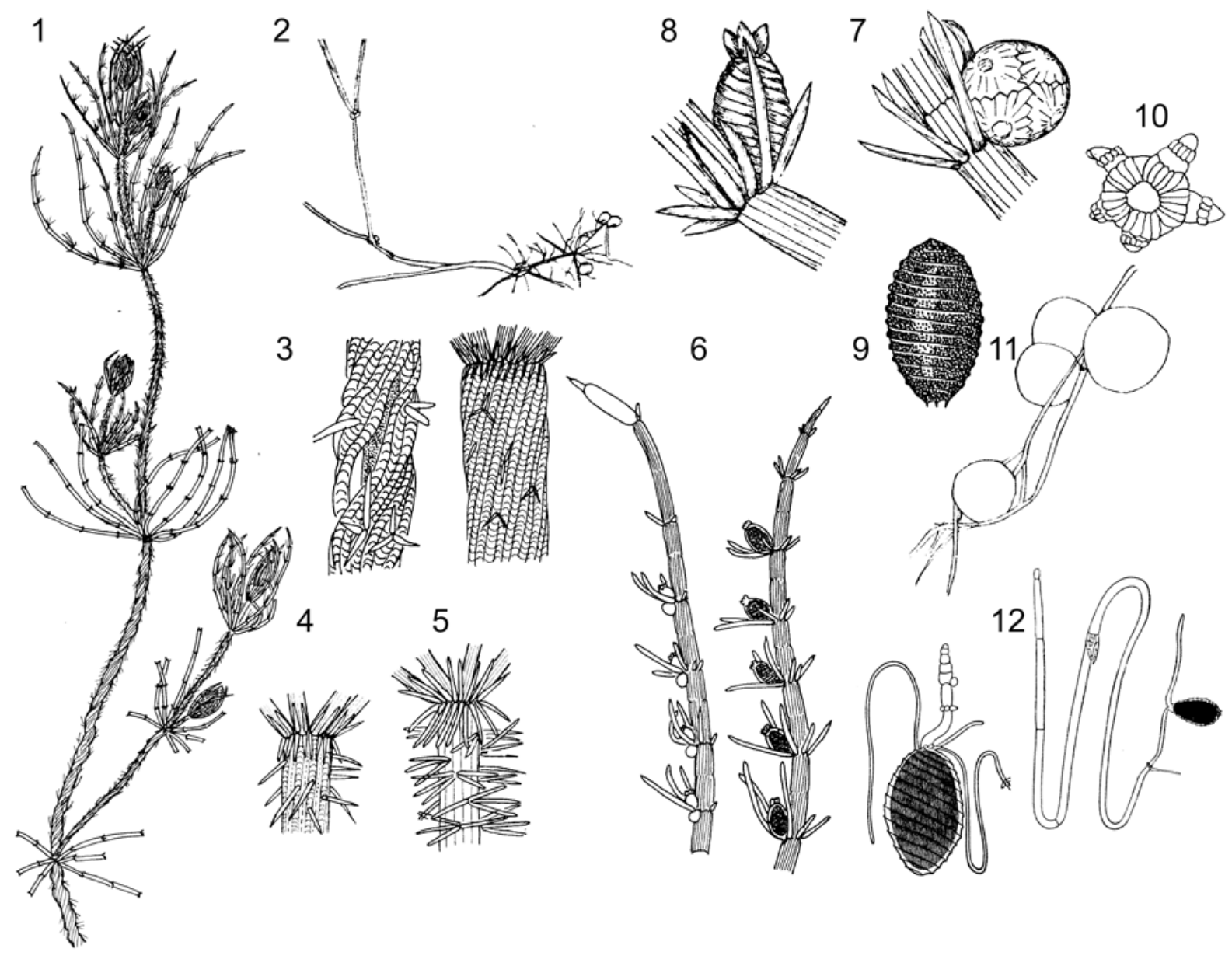

Figs 1-12. The morphology of Charales: the main stem is composed of nodes with whorls of branchlets and internodes (Fig. 1; after KRAUSE 1997), basal part is formed of rhizoids (Fig. 2; after DAMBBSKA 1964). Surface of the stem is covered with cortical and spine cells (Fig. 3; after KRAUSE 1997). The stipuloide cells (Fig. 4; after DAMBSKA 1964) are arranged at the basis of the branchlet whorls at the nodes. The presence of the features mentioned above varies from species to species. The cortex of the stem is formed of longitudinally arranged rows of cells with the spine cells organized solitarily (Fig. 4) or in clusters (Fig. 5; after KRAUSE 1997). The cells are of various appearances (e.g. elongated, shortened). The unique reproductive organs (Fig. 6; after KRAUSE 1997), antheridia (Fig. 7; after DĄMBSKA 1964) and oogonia (Fig. 8; after DÅMBSKA 1964) occur in association with bracteoles at the whorls of branchlets. Both gametangia are wrapped in protective cells with specific ornamentation. Mature oogonia (Fig. 9; KRAUSE 1997) are brown or black and contain only one egg cell, whereas antheridia are bright orange due to the carotenoid layer and contain thousands of biflagellate spermatozoids. The zygote with protective cells is formed after the fertilization. As another type of reproduction is usage of special vegetative branchlets originated in either nodal complex or white star-shaped (Fig. 10; DAMBBSKA 1964) or spherical structures (bubils; Fig. 11; after DAMBSKA 1964). The prochara (prothallus; Fig. 12; after VILHELM 1914) is formed after the fertilization or the asexual reproduction. 
is presence or absence of corticated cells. The members of the Chareae may be ecorticated or corticated, whereas the members of the tribe Nitelleae are always ecorticate.

The presence of bract cells and double row of stipuloides and stem covering with cortical and spine cells are typical for many Chara species. The plants can sometimes be encrusted by calcium carbonate. The features of the three Nitellopsis species include absence of stipuloides and cortex, but the presence of the starch-storage organs (bubils) with a typical appearance (white colour and star or spherical shape). The cortex, stipuloides, spine cells and bract cells are absent in genus Nitella (53 species, 200 infraspecific taxa) and Tolypella (two species and ten infraspecific taxa). The rays of Nitella may consist of one to three cells, whereas the rays of Tolypella are always multicellular. The Tolypella species may accumulate lime (like Chara) and become encrustated.

\section{General ecological demands}

Members of Charophyta are recorded from both freshwater habitats and brackish waters (KRAUSE 1997). However, according to some studies (e.g. ElLIotT 1984) some of the ancestral forms (e.g. Karspinskya) were marine. At the present time, salinity is regarded as limiting factor for survival of charalean algae (DAMBSKA 1964). Charophytes form part of submerged vegetation in permanent or temporary lakes, pools, streams and rivers. They also can be found in calceorus rich fens (GĄBKA 2007, URBANiAK et al. 2008). The majority of the species are known from the temperate zone, but they endure polar conditions as well. Environmental factors (e.g. water temperature and chemistry, light and altitude) have a considerable impact on the distribution of Charophytes (e.g. DAMBBSKA 1964, Krause 1981, HaAs 1994, Blindow 1992, Blindow \& Langangen 1995, Pelechaty et al. 2004, GĄBKA et al. 2007, BoszKe \& BociąG 2008). Much attention in present research is paid to the interrelation of charophytes with phytoplankton (SCHEFFer 1989, SChefFer \& JePPENSEN 1998, SCHEFFER 2001). In shallow waters charophytes meadows suppress growth of phytoplankton and influence water quality, especially impacting on transparency (VAn Den Berg et al. 1998, VAn Den BERG et al. 1999).

Charophytes occur in both mildly acid and alkaline waters $(\mathrm{pH} 7-8)$. The $\mathrm{pH}$ limit ranges from 5 (Chara globularis, OLSEN 1944) to 9.5 (Chara braunii, CoRILlon 1975). Nitelleae prefer $\mathrm{pH}$ 6-8 and Chareae prefer the $\mathrm{pH}$ range 7-9 (DĄMBSKA 1964). Phosphorus, iron oxide and calcium carbonate are other abiotic factors influencing charophyte growth and abundance. However, the knowledge about sediment and elemental requirements of Charophyta is poor (Vilhelm 1914, Dambiska 1964, Grant et al. 1971, Grant 1990, HaAs 1994, Torn et al. 2004). Generally, the appearance of the thallus or plant depends on the environmental conditions under which they are growing (Migula 1897, Wood \& IMAHORY 1965, CORILlion 1975, BonNis \& Grillas 2002, BoszKe \& BocIĄG 2008).

\section{History of the research in Czech Republik}

Most of the genera and species have been described during the last five centuries by many authors: e.g. BaUhin (1620), Vaillant (1721), LinNaEus'(1753), Agardh (1824), Braun (1849), Ruprecht (1845), Leonhardi (1863), Groves (1916), Hy (1889) and VilHelm (1914).

The first references on Charophyta in Bohemia were recorded by Presl (1846) and GANTERER (1847). However, they both mentioned only a few improperly defined species without any evidence about their distribution and ecological demands. The first information about charophytes comes from herbarium materials from 1802 (Moravia). A more elaborate (complex) study focused on the genus Chara and Nitella was published by OpIz (1852). He recognised 7 species of charophytes in Bohemia. The first detailed investigation of Charales was released by LEONHARDI (1863). He pointed out the mistakes in Opiz's characterization of genus Chara and Nitella and proposed a list of species in Bohemia (16 species). ČElakovsKÝ (1878, 1887), Braun (1876) and Hora (1883) were also interested in Charales in Bohemia. Occurrence of charophytes in Bohemia was presented in Die Characen Deutschlands, Österreichs und Schweiz (1897) by Migula. Based on prior publications Migula (1897) gathered and summarized information about 19 species of charophytes. The most recent report focusing on Charales species diversity and distribution in the Czech Republic along with ecological demands was a checklist of Charales species published by Vilhelm $(1914,1922,1925)$. 
Vilhelm (1914) recognised 22 species from genus Chara, Nitella, Nitellopsis and Tolypella on the basis of modern species concepts. He also recognised existence of such taxa as Chara hippeliana (VILH.) R. D. W., Ch. pannonica VILH. and Ch. bohemica (VILH.) R. D. W.

Chara braunii Gm., Ch. vulgaris L., Ch. globularis Thuill. and Nitella opaca (BRuz.) Ag. were widespread species in the whole Bohemia during $19^{\text {th }}$ century and at the beginning of $20^{\text {th }}$ century, Chara braunii was recorded especially in Třeboň region (VILHeLm 1914). Whereas $C h$. aspera Deth. ex Willd., Ch. canescens Desv. et LoIs. in LoIs., Ch. contraria A. Br. ex KüTz., Ch. hispida L., Nitella capillaris (Krok.) J. Groves et Bullock-Webster, $N$. gracilis (Sм.) Ag. and Tolypella glomerata (Desv. in Lois.) R. D. W. were restricted to central Bohemia (Kralupy, Neratovice and Prague regions) and northern Bohemia. Chara delicatula Ag., Nitella syncarpa (Thuill.) Chev., N. flexilis (L.) Ag., N. mucronata (A. BR.) MiQ. and Tolypella prolifera (Ziz. ex A. BR.) R. D. W. were recorded rarely (LEONHARDI 1863, ČelakovskÝ 1876, Vilhelm 1914).

Although we have a lot of records about the distribution and ecological demands of Charales in Bohemia from the $19^{\text {th }}$ century (HANSGIRG 1892, Lhotský \& Rosa 1955, Poulíč́Ková et al. $2004)$, there is poor knowledge from the $18^{\text {th }}$ and $20^{\text {th }}$ centuries, because only a few people were interested in Charales (Lhotský \& Rosa 1955, HusÁk 1985, Husák 2001, DĄmBSKa, HejnÝ and Prague herbarium materials). According to LEONHARDI (1863) and VilHeLM $(1914,1922)$ more than $40 \%$ of species of Charophytes distributed in Europe (KRAUSE 1997, BLAŽENČIĆ et al. 2006) were recorded in Bohemia. Our revision of herbarium materials makes it also possible to identify a taxon new to Czech - Chara polyacantha (A. BR.). KRAuSE (1997) and BlažENČIĆ et al. (2006) present the River Labe basin as the region with the highest abundance of Charales. However, they pointed out the decrease of localities as well. Drainages and climate changes (drying and freezing of corresponding habitats) and primary eutropication are probably the main causes of the decline of Charophyta.

\section{Species diversity in the Czech Republic}

Data for present paper has been gathered from numerous literature results, revision of herbarium materials and our field research (eg. CAISOVÁ et al. 2007). We have studied specimens from the following herbarium collections from Czech: (National Muzeum in Prague, The Moravian Museum, Museum of Central Bohemia in Roztoky near Prague and private collections) and Poland: Poznań (DĄMBSKa collection, placed in Deparment of Hydrobiology, Adam Mickiewicz University). The charophyte species were determined according to the DAMBBSKA's (1964) and KRAUSE's (1997) identification keys and data reported by VILHELM (1914).

Twenty six of the 63 known species of charophytes in Europe have been found in waters of the Czech Republic (KRAuse 1997, BLažEnČIĆ et al. 2006). Charophyte species found so far are representatives of four of the six known genera in Europe (Chara, Nitella, Nitellopsis and Tolypella). Characeae were found in over 1000 different localities. We present complete check list of charophytes from Czech. Nowadays, members of Charales in the Czech Republic are classified into five categories according to frequency of their occurrence (HusáK, pers. comm.): Vanishing species: Chara intermedia, Chara polyacantha, Chara rudis, Chara tomentosa, Nitella tenuissima, Nitellopsis obtusa, Tolypella intricata, Tolypella prolifera; Critically endangered species: Chara canescens, Chara gymnophylla, Nitella batrachosperma, Nitella capillaris, Nitella mucronata, Tolypella glomerata; Highly endangered species: Chara aspera, Chara connivens, Chara contraria, Chara delicatula, Nitella gracilis, Nitella syncarpa; Endangered species: Chara braunii, Chara hispida, Nitella opaca; Common species: Chara globularis, Chara vulgaris, Nitella flexilis (VILHelm 1914, Lhotský \& Rosa 1955, Husák 2001, Poulíč́ová et al. 2004, herbarium material, private collections and original data).

Four species in the Czech Republic are noted as especially rare and endangered in Europe: Nitella tenuissima (Desv.) Kütz., $N$. batrachosperma (RеICH.) A. Br., Chara connivens SAlzm. ex A. Br. and C. polyacantha (Krause 1997, BLAŽEnČIĆ et al. 2006, URbaniaK et al. 2008).

Nowadays research on the distribution and ecology of charophytes in the Czech Republic can specify types of habitat of individual species. It should be emphasized that ponds, small water reservoirs, river and brackish waters are especially important for preservation of biodiversity of 
charophytes in Czech. Ecological demands of Charales in the Czech Republic are summarized in Table 1.

There are indications that species that are rare in the Czech Republic may occur sporadically, but have a wider distribution within Europe e.g. Nitella mucronata (GRULICH \& VYDROVÁ 2006, CAISOVÁ et al. 2008). Generally, there is only poor knowledge about the distribution of Charales in Bohemia. Further research of Charales species is needed to develop deeper knowledge of their morphology, ecological requirements and their distribution in the Czech Republic.

\section{Species description}

Nomenclature is adjusted according to KRAUSE (1997) and synonyms selected for this review are that frequently used in database of published records from Czech Republic (PoulíčKová et al. 2004). Other synonyms see in WoOd \& IMAHORI (1965) and Krause (1997).

The morphology of charophytes have been described according to VILHELM (1914), DAMBSKA (1964), KRAUSE (1997) and confirmed species from herbarium materials. The main known ecological requirements for each species are summarized in Table 1 (VILhelm 1914, Dąmbska 1964, HaAs 1994, KRAuse 1997 and Husák pers.comm,).

Chara aspera Deth. ex Willd., Ges. Naturf. Freunde, 3: p. 298, 1809; Figs 13-21.

Synonyms: Chara aspera f. longispina Mig., Rabenh. Krypt. Fl., p. 661, 1897, incl.; Chara aspera f. brevispina A. Br. in Vilhelm, Mém. Soc. Roy. Sci. Boheme, p. 146, 1914, incl.; Chara aspera f. brevifolia Vilhelm, Mém. Soc. Roy. Sci. Boheme, p. 147, 1914, incl. - WOOD \& IMAHORI, 1965: p.162.

The appearance varies widely (Figs 14-15, 21). Stem: up to 5-40 cm tall, slender, brown, grey to green, heavily incrustated (from freshwater) or without incrustation (from brackish water). Cortex: triplostichous, isostichous to tylacanthous. Spine cells: usually solitary or in clusters of 2-3, the size of axis diameter or longer, acute (Figs 18-19). Stipulodes: in 2 well developed rows, acuminate (Fig. 18). Internodes: firm, corticated, 1-3 (4) times the length of the branchlets (Fig. 14). Branchlets: $6-8$ (11) branchlets in a whorl (Fig. 15), upper 1-2 segments may be ecorticated.
Terminal cells of branchlets: reduced. Bracteoles: longer than the oogonium. Plants dioecious. Gametangia: separate or conjoined at lowest 3-4 branchlet nodes, without mucus. Oogonia: solitary, 600-1000 x 400-700 $\mu \mathrm{m}$ (Fig. 16), mature oospores dark brown to black colour with marked stripes and granulated (Fig. 17). Antheridia: solitary and smaller (Fig. 16). Bulbils: unicellular, whitish, clustered and singly or most often 2-4, common (Fig. 20).

Ecology: Fresh (especially calcareous) and brackish waters, mainly in shallow fishponds, drainage canals, lakes and peat lands.

Distribution: Common in Europe, North Africa (DAmBsKa 1964, Wood \& IMAhory 1965, KRAUSE 1997). It has been reported from southern Asia and North America. Not yet known from Australia and South America (WoOd \& IMAHORY 1965, KRAUSE 1997). There have been local sightings also (20 sites) in the Czech Republic (Fig. 13).

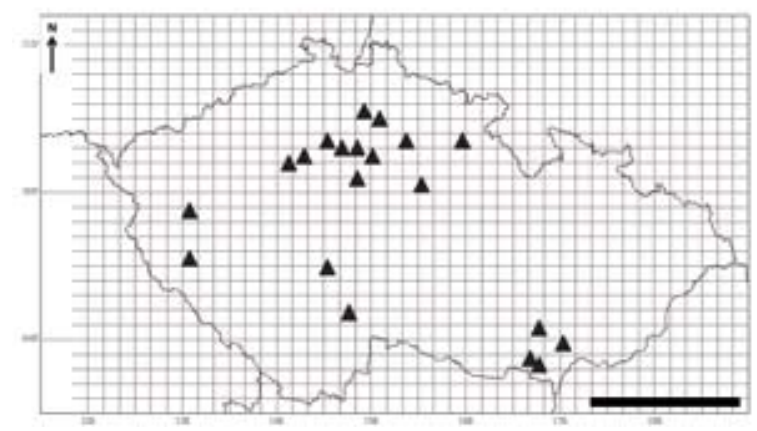

Fig. 13. Distribution of Chara aspera in the Czech Republic (scale bar $100 \mathrm{~km}$; for localities see attachment).

Chara braunii Gm., Fl. Badens. Alsat. (Suppl.), 4: p. 646, 1826; Figs 22-29.

Synonyms: Chara coronata Ziz ex Bischoff, Krypt. Gewächse, p. 1, 1828; Chara braunii f. maxima Mig., Rabenh. Krypt. Fl., p. 329, 1897, incl.; Chara braunii f. laxior Vilhelm, Mém. Soc. Roy. Sci. Boheme, p. 94, 1914, incl. - Wood \& Imahori, 1965: p. 257; Krause, 1997: p. 117.

Stem: up to 3-20 (50) cm tall, slender or robust, weakly branched, pale to brownish green, transparent, usually without incrustation (Figs 23-24). Cortex: ecorticated species. Spinecells: absent. Stipulodes: in a single whorl, well developed (Fig. 26). Internodes: slender, uncorticated, variable in length (Fig. 23). Branchlets: 6-11 in a whorl (Fig. 23), upper 

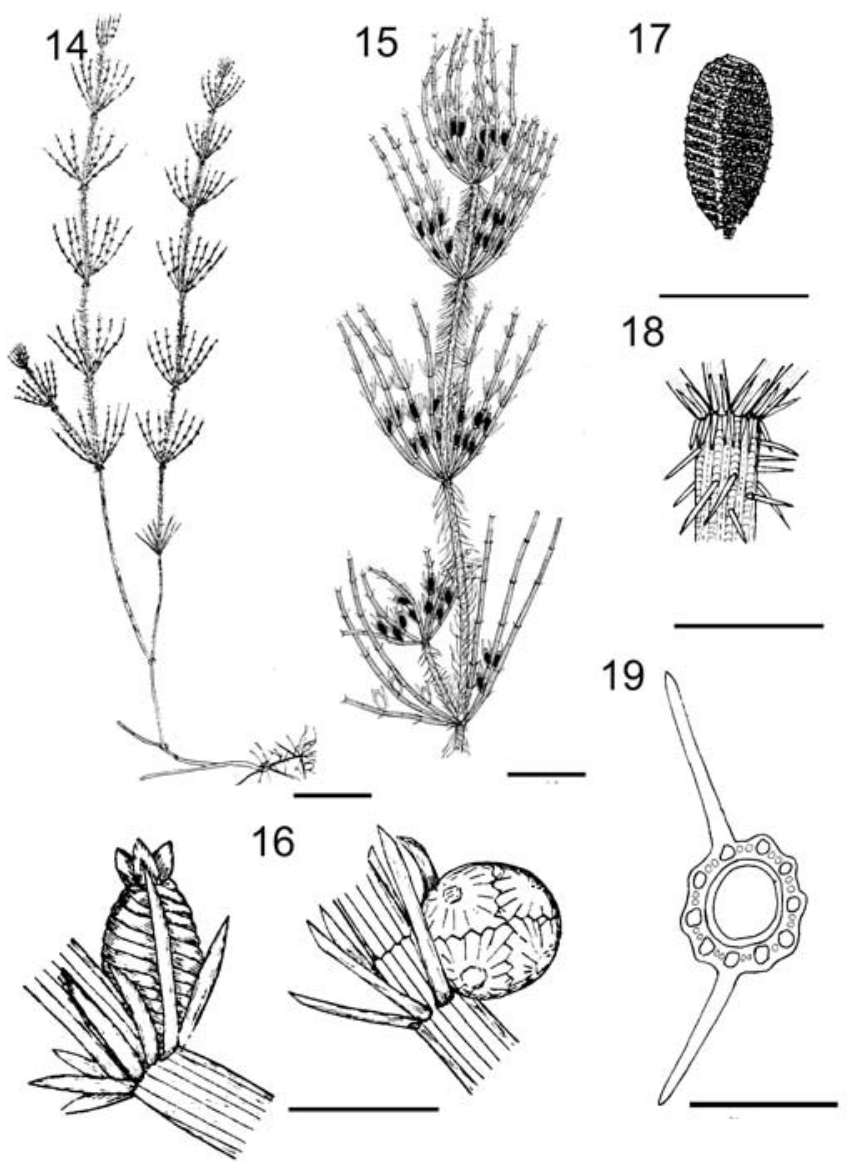

18
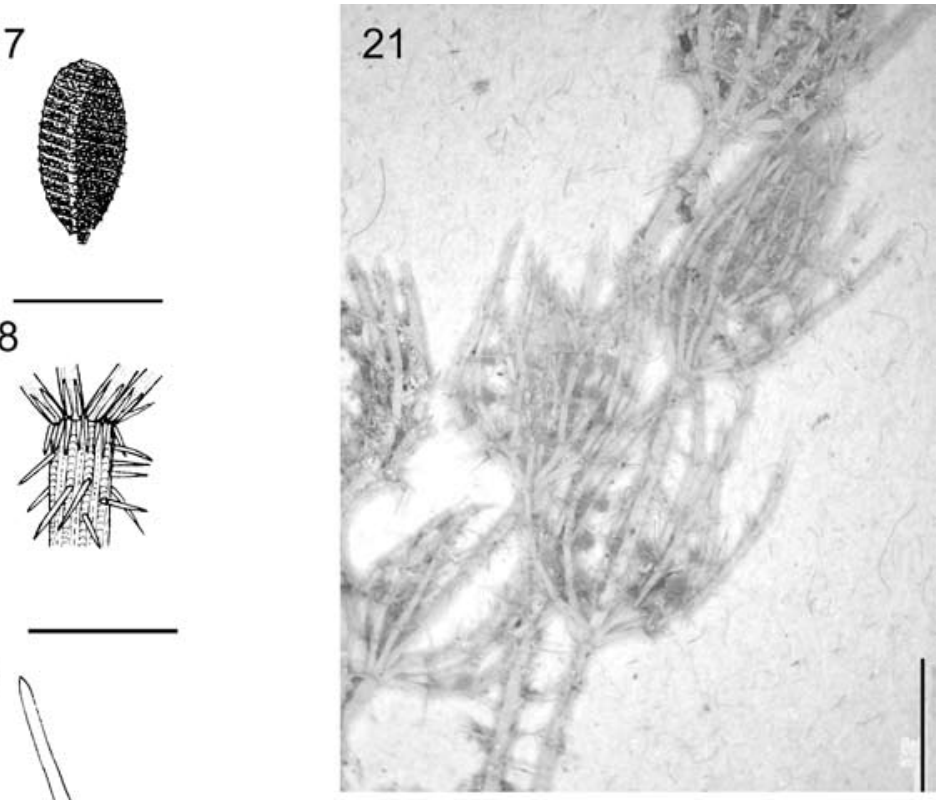

20

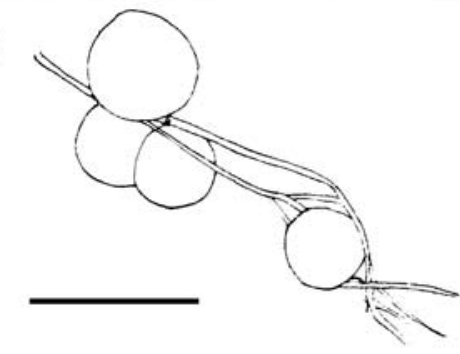

Figs 14-21. Chara aspera [(14, 17-19) after Krause (1997); (15-16, 20) after DąmBSKA (1964); (21) orig. CAisové]: (14-15, 21) macroscopic habitus; (16) branchlet node with oogonia and antheridia; (17) oospore; (18) stipulodes and spines; (19) internode cross-section; (20) bubils. Scale bars $0.2 \mathrm{~cm}$ (Fig. 20), $0.5 \mathrm{~cm}$ (Figs 16-19) and $1 \mathrm{~cm}$ (Figs 14, 15, 21).

1-2 short. Terminal cells of branchlets: slightly reduced, sharp, forming tiny terminal corona or mucro (Fig. 25). Bract cells: shorter than the oogonium. Plants monoecious. Gametangia: conjoined at 2-3 lowest branchlet nodes, without mucus. Oogonia: solitary or 2-3 together, 510850 x 375-530 $\mu \mathrm{m}$ (Figs 26-28), mature oospores dark brown to black colour with marked stripes and slightly granulated (Fig. 29). Antheridia: 2-3 together or solitary, $300 \mu \mathrm{m}$ in diameter (Figs 2627). Plants very richly fertile.

Ecology: Mainly in fish keeps and shallow fishponds with sand, silt or clay bottom.

Distribution: Worldwide, records from Australia, North and Central America, Asia and Europe (DAmbska 1964, Wood \& Imahory 1965, Krause 1997). In Europe it has been very widely reported from Germany, Slovakia, Austria, Denmark, Poland, Finland, Norway, Sweden, Russia, Greece, Albania and Iberian Peninsula (WoOd \& IMAHORY 1965, Krause 1997 and URBANiaK 2007a,b). In the Czech Republic, more than 50 sites have been expecially reported from a part of Bohemia region (Fig. 22).

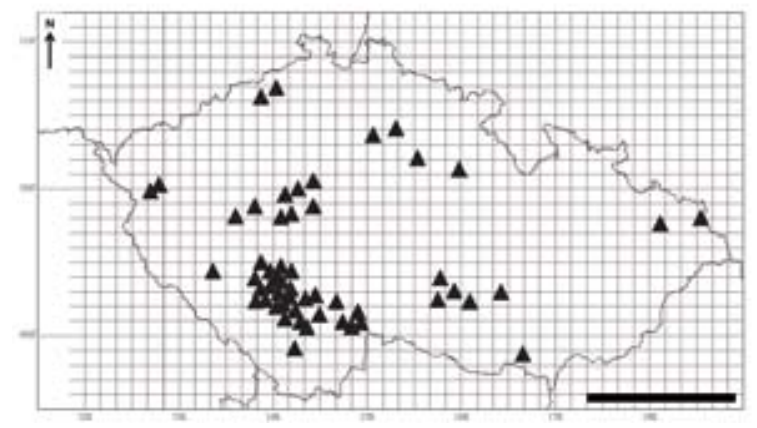

Fig. 22. Distribution of Chara braunii in the Czech Republic (scale bar $100 \mathrm{~km}$; for localities see attachment). 


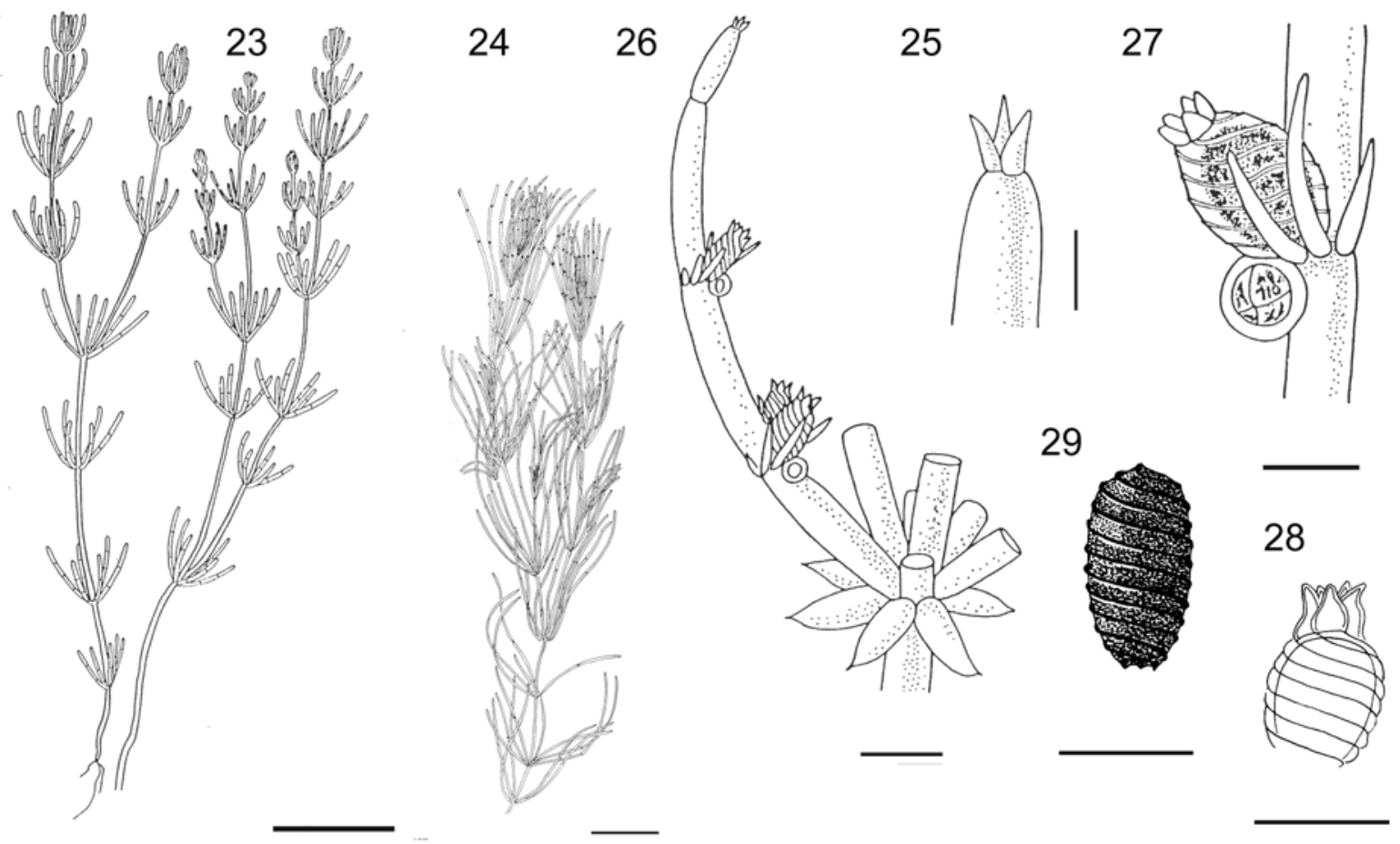

Figs 23-29. Chara braunii [(23, 25-27) after Wood \& IMAHory (1965); (24, 28-29) after Krause (1997)]: (23-24) macroscopic habitus; (25-28) branchlet node with oogonia and antheridia; (29) oospore. Scale bars $0.2 \mathrm{~cm}$ (Fig. 28), $0.5 \mathrm{~cm}$ (Figs 25, 27 , 29) and $1 \mathrm{~cm}$ (Figs 23-24, 26).

Chara canescens DEsv. et LoIs. in LoIs., Deslong., Not. Pl. Fl. France., p. 139, 1810; Figs $30-37$.

Synonyms: Chara crinita Wallroth, Ann. Bot., p. 190, 1815. - WoOd \& IMAHORI, 1965: p. 154; KRAUSE, 1997: p. 64.

The appearance varies widely (Figs 31-33, 37). Stem: up to $5-50 \mathrm{~cm}$ tall, slender, pale green, without incrustation or poorly incrustated. Cortex: haplostichous. Spine cells: in clusters, 2 times longer than the axis of the diameter, density acuminates (Figs 33, 36-37). Stipulodes: in 2 well developed rows, acuminate (Fig. 36). Internodes: firm, 2-4 times the length of the branchlets (Figs 31, 33). Branchlets: $5-10$ branchlets in a whorl, 5-8 segments, and end cells may be encortcated (Fig. 33). Terminal cells of branchlets: slightly reduced. Bracteoles: well developed, shorter than the oogonium. Plants dioecious or rarely monoecious. In Czech only female plants are found. Gametangia: solitary or conjoined at all branchlet nodes, without mucus. Oogonia: solitary or geminate, $550-850 \times 278-550 \mu \mathrm{m}$ (Fig. 34), mature oospores dark brown to black colour with marked stripes (Fig. 35). Antheridia: smaller than oogonia, 500-700 $\mu \mathrm{m}$ in diameter
(Fig. 34).

Ecology: Only in brackish shallow waters.

Distribution: Worldwide, records from South America, Africa, Asia, Europe (DAmBSKA 1964, KRAUSE 1997, BlAžENČIĆ et al. 2006). In Europe it has been reported from Germany, Italy, Hungary, Slovakia, Spain, Poland and France and from Balkan, and it is also known from a few localities in Norway, Sweden and Denmark (KRAUSE 1997). There have been local sightings from 8 sites also in the Czech Republic (Fig. 30).

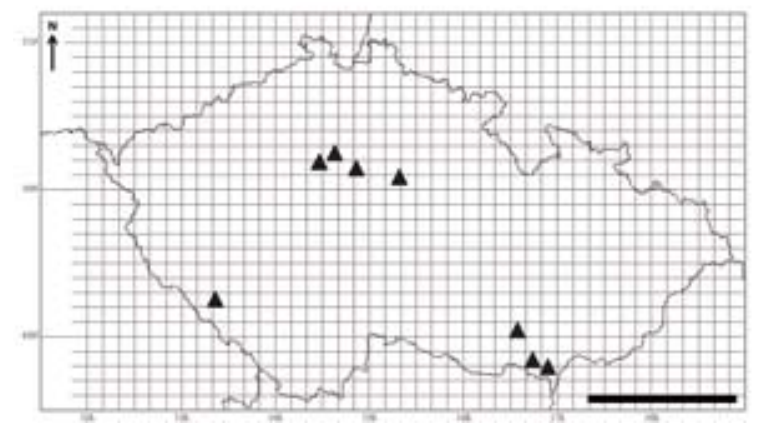

Fig. 30. Distribution of Chara canescens in the Czech Republic, scale bar $100 \mathrm{~km}$. For description of localities see attachment. 


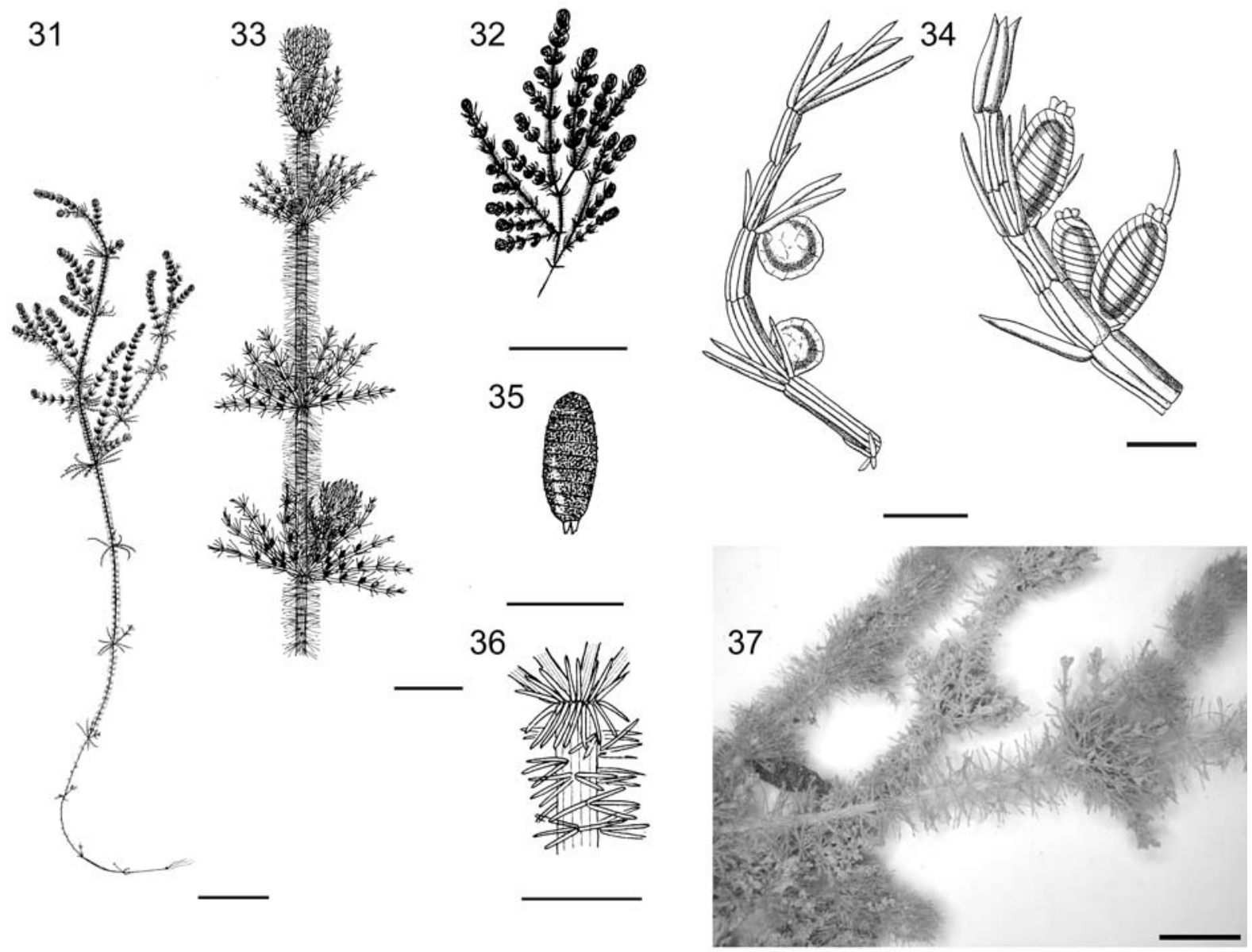

Figs 31-37. Chara canescens [(34) after Wood \& Imahory (1965); (31-33, 35-36, 37) after Krause (1997); (37) orig. CAISOVÁ]: (31-33, 37) macroscopic habitus; (34) morphology of oogonia and antheridia; (35) oospore; (36) stipulodes and spines. Scale bars $0.5 \mathrm{~cm}$ (Figs 34-36) and $1 \mathrm{~cm}$ (Figs 31-33, 37).

Chara connivens SALzm. ex A. BR., Fl., 18: p. 73, 1835; Figs 38-46.

Synonyms: WoOd \& IMAHORI, 1965: p. 176 ; KRAUSE, 1997: p. 91.

Stem: up to $9-40 \mathrm{~cm}$ tall, slender, yellow or grey to green, lightly incrusted (Figs 39-41). Cortex: triplostichous and isostichous; Spine cells and stipulodes: reduced papiliform (Figs 45-46). Internodes: firm, corticated, 1-2 (6) times the length of the branchlets (Figs 39-40, 45). Branchlets: 6-10 in a whorl, short, strongly connivent (Figs 40-41), 8-10 segments, upper 1-2 may be ecorticated. Terminal cells of branchlets: reduced. Bracteoles: shorter than the oogonium. Plants dioecious. Gametangia: solitary at 1-4 lowest branchlet nodes, without mucus. Oogonia: solitary, 675-750 x 150-180 $\mu \mathrm{m}$ (Figs 42-43), mature oospores dark brown to black colour with marked stripes and slightly granulated (Fig. 44). Antheridia: solitary, clear orange and large, up to
$1000 \mu \mathrm{m}$ in diameter (Fig. 42).

Ecology: Brackish waters and occasionally in fresh eutrophic waters with higer conductivity.

Distribution: Worldwide, Africa, Asia and Europe (DĄmBSKA 1964, Wood \& IMAHORY 1965, KRAUSE 1997). In Europe it has been reported from Germany, Slovakia, France, Spain, Portugal,

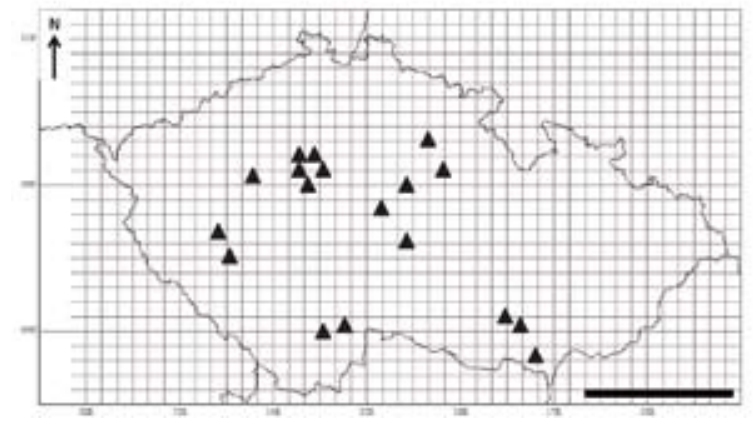

Fig. 38. Distribution of Chara connivens in the Czech Republic (scale bar $100 \mathrm{~km}$; for localities see attachment). 

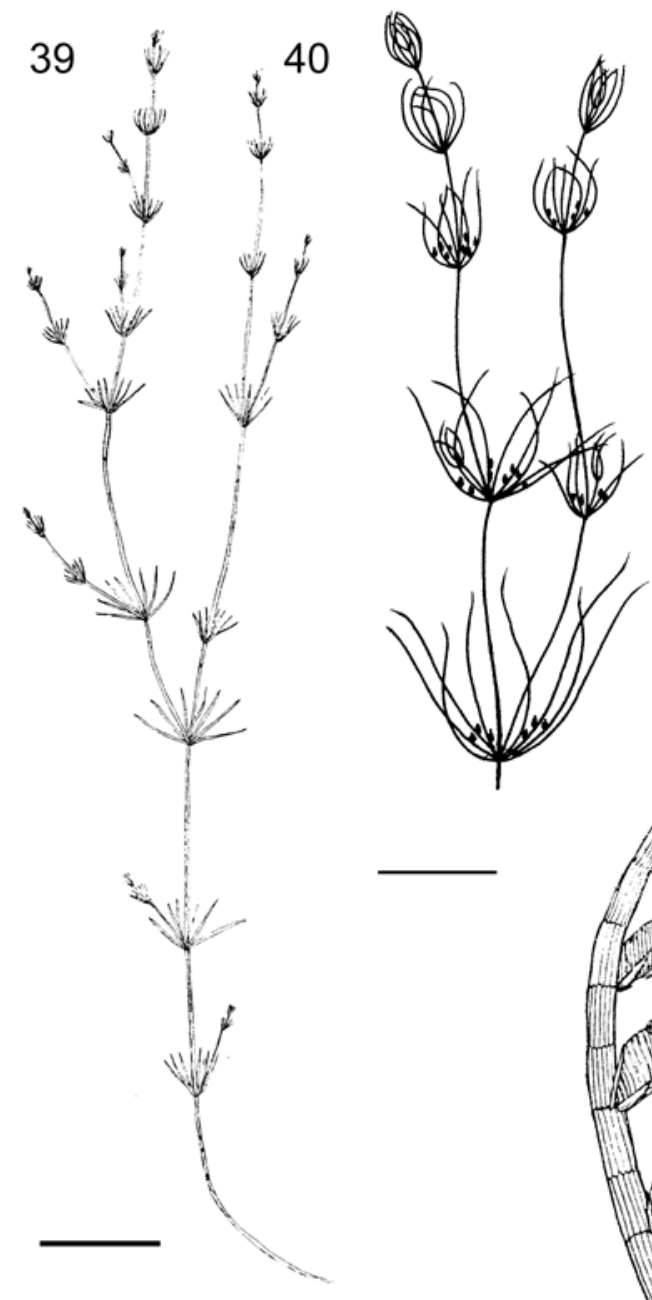
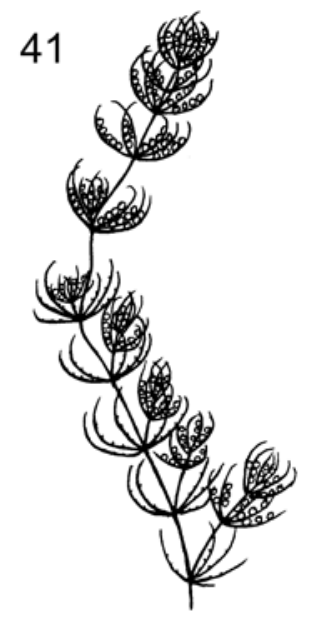

43

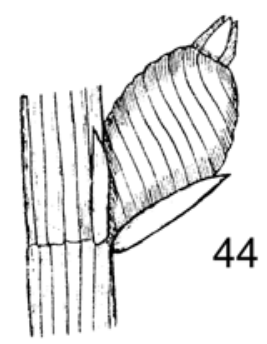

44

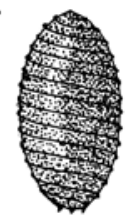

45

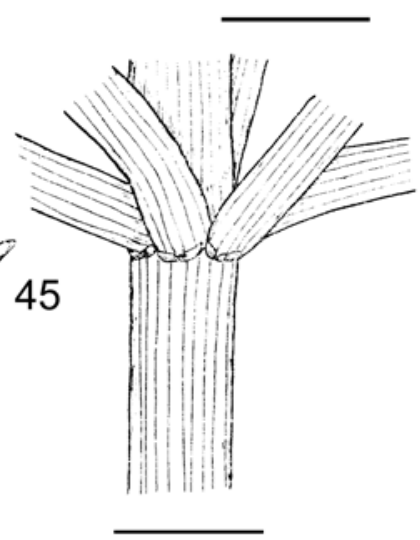

46

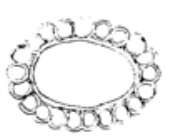

Figs 39-46. Chara connivens [(39, 42, 45-46) after DAMmBKA (1964); (40-41, 43-44) after KraUSE (1997)]: (39-41) macroscopic habitus; (42-43) branchlet node with oogonia and antheridia; (44) oospore; (45) internodes; (46) internode cross-section. Scale bars $0.2 \mathrm{~cm}$ (Fig. 43), $0.5 \mathrm{~cm}$ (Figs 42, 44, 46) and $1 \mathrm{~cm}$ (Figs 39-41, 45).

Poland, Great Britain, Irland and Balkans (Wood \& IMAHORY 1965, KRAUSE 1997, BlažENČIĆ et al. 2006). In the Czech Republic has been reported to be relatively common species (17 sites) (Fig. 38).

Chara contraria A. Br. ex KüTz., Phyc. Germ., p. 258, 1845; Figs 47-55.

Synonyms: Chara contrania f. communis Mig., Rabenh. Krypt. Fl., p. 443, 1897, incl.; Chara contrania f. bohemica Vilhelm, Mém. Soc. Roy. Sci. Boheme, p. 100, 1914, incl.; Chara contraria f. brachyphylla Vilhelm, Mém. Soc. Roy. Sci. Boheme, p. 99, 1914, incl.; Chara contraria f. leptosperma Vilhelm, Mém. Soc. Roy. Sci. Boheme, p. 102, 1914, incl.; Chara contraria f. polysperma Vilhelm, Mém. Soc. Roy. Sci. Boheme, p. 98, 1914, incl.; Chara contraria f. turfosa Vilhelm, Mém. Soc. Roy. Sci. Boheme, p. 99, 1914, incl.; Chara contraria v. hispidula f. leptosperma A. BR. in Vilhelm, Mém. Soc. Roy. Sci. Boheme, p. 101, 1914, incl. - Wood \& Imahori, 1965: p. 92; Krause, 1997: p. 83.

The appearance varies widely (Figs 48-50). Stem: up to 5-20 (90) $\mathrm{cm}$ tall, slender, grey, brown to dark green, usually strongly incrusted. Cortex: diplostichous, tylacanthous. Spine cells: solitary, often short or papilliform (Figs 50, 55). Stipulodes: short in 2 rows (Fig. 54). Internodes: firm, corticated, 2-4 times the length of the branchlets (Figs 49-50, 54). Branchlets: 7-10 in a whorl (Figs 48-50), 4-7 segments, usually with a few segments completely ecorticated. Terminal cells of branchlets: conical or slightly reduced. Bracteoles: usually longer than the oogonium. 
Plants monoecious. Gametangia: separate, geminate or conjoined at each $1-4^{\text {th }}$ branchlet nodes, without mucus. Oogonia: solitary or geminate, incrusted, 645-975 x 375-575 $\mu \mathrm{m}$ (Figs 51-52), mature oospores dark brown to black colour with marked stripes and granulated ornamentation (Fig. 53). Antheridia: small, up to $400 \mu \mathrm{m}$ in diameter (Figs 51-52).

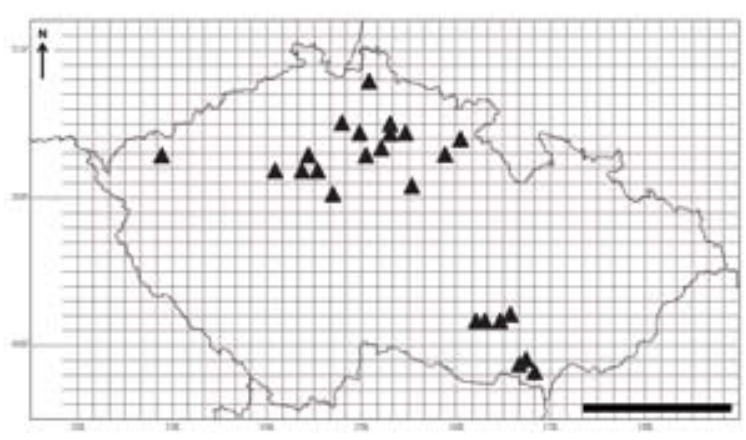

Fig. 47. Distribution of Chara contraria in the Czech Republic (scale bar $100 \mathrm{~km}$; for localities see attachment).
Ecology: Calcium-rich freshwater reservoirs with sand or mud bottom and fish keeps, occasionally in brackish ecosystems.

Distribution: Worldwide, records from South and Central America, Australia, Asia and Europe (DĄmBSKa 1964, Wood \& IMAhory 1965, KRAUSE 1997). In Europe it has been commonly reported from e.g. Germany, Slovakia, Austria, Poland, Denmark and France (WoOd \& IMAHORY 1965, Krause 1997). In the Czech Republic it has been recorded from 24 sites (Fig. 47).

Chara delicatula Ag., Syst. Alg., p. 130, 1824; Figs 56-64.

Synonyms: Wood \& Imahori, 1965: p. 183; Krause, 1997: p. 89.

The appearance varies widely (Figs 57-59). Stem: up to $25 \mathrm{~cm}$ tall, slender, pale to dark green, moderately incrustated, often in clumps. Cortex: regular triplostichous. Spine cells: solitary, short or papilliform (Fig. 64). Stipulodes: in 2 rows, upper row well developed and acute, lower

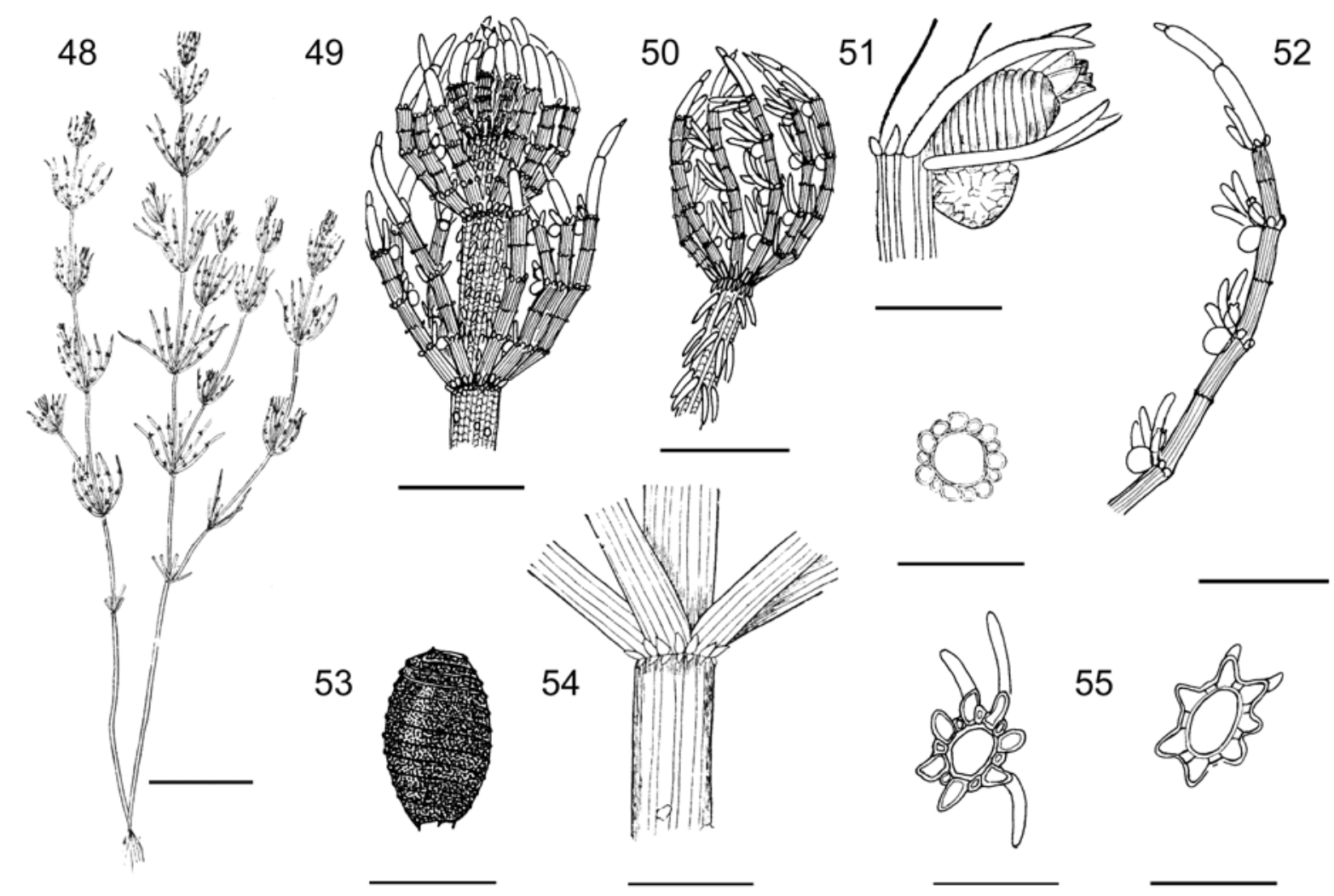

Figs 48-55. Chara contraria [(48, 51-52, 54-55) after DAMBSKA (1964); (49-50, 53) after KrauSE (1997)]: (48-50) macroscopic habitus; (51-52) branchlet node with oogonia and antheridia; (53) oospore; (54) internodes, stipuloides; (55) internode crosssection. Scale bars $0.5 \mathrm{~cm}$ (Figs $51-55)$ and $1 \mathrm{~cm}$ (Figs 48-50). 
small and papilliform (Fig. 64). Internodes: firm, corticated, 1-2 (5) times the length of the branchlets (Figs 58, 64). Branchlets: 6-9 in a whorl, straight to incurved, upper 1-3 may be ecorticated. Terminal cells of branchlets: conical or sharp, slightly reduced. Bracteoles: 1-2 times longer than the oogonium. Plants monoecious. Gametangia: conjoined or sejoined at lowest 1-3(4) branchlet nodes, without mucus. Oogonia: solitary, 750-1000 x 500-675 $\mu \mathrm{m}$ (Figs 61-62), mature oospores dark brown to black colour with market stripes, granulate or papillate (Fig. 63). Antheridia: small, often up to $400 \mu \mathrm{m}$ in diameter (Figs 61-62). Bulbils: common, whitish and multicellular (var. bulbillifera) (Fig. 60). Plants richly fertile.

Ecology: Freshwaters, especially in fish keeps, ponds and ditches with different type of bottoms and wide spectrum of trophy and calcium contents. Species was also recorded under ice cover.
Distribution: Worldwide, records from North America, Africa, Asia and Europe (DĄmBSKa 1964, KRAUSE 1997). In Europe it has been reported commonly from e.g. Norway, Great Britain, Germany, Denmark, Poland, the Netherlands, France and Spain (Krause 1997). In the Czech Republic it has been reported from 17 sites (Fig. 56).

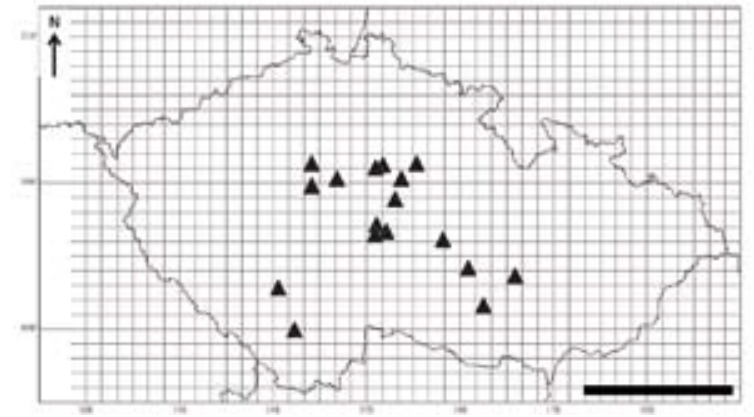

Fig. 56. Distribution of Chara delicatula in the Czech Republic (scale bar $100 \mathrm{~km}$; for localities see attachment).
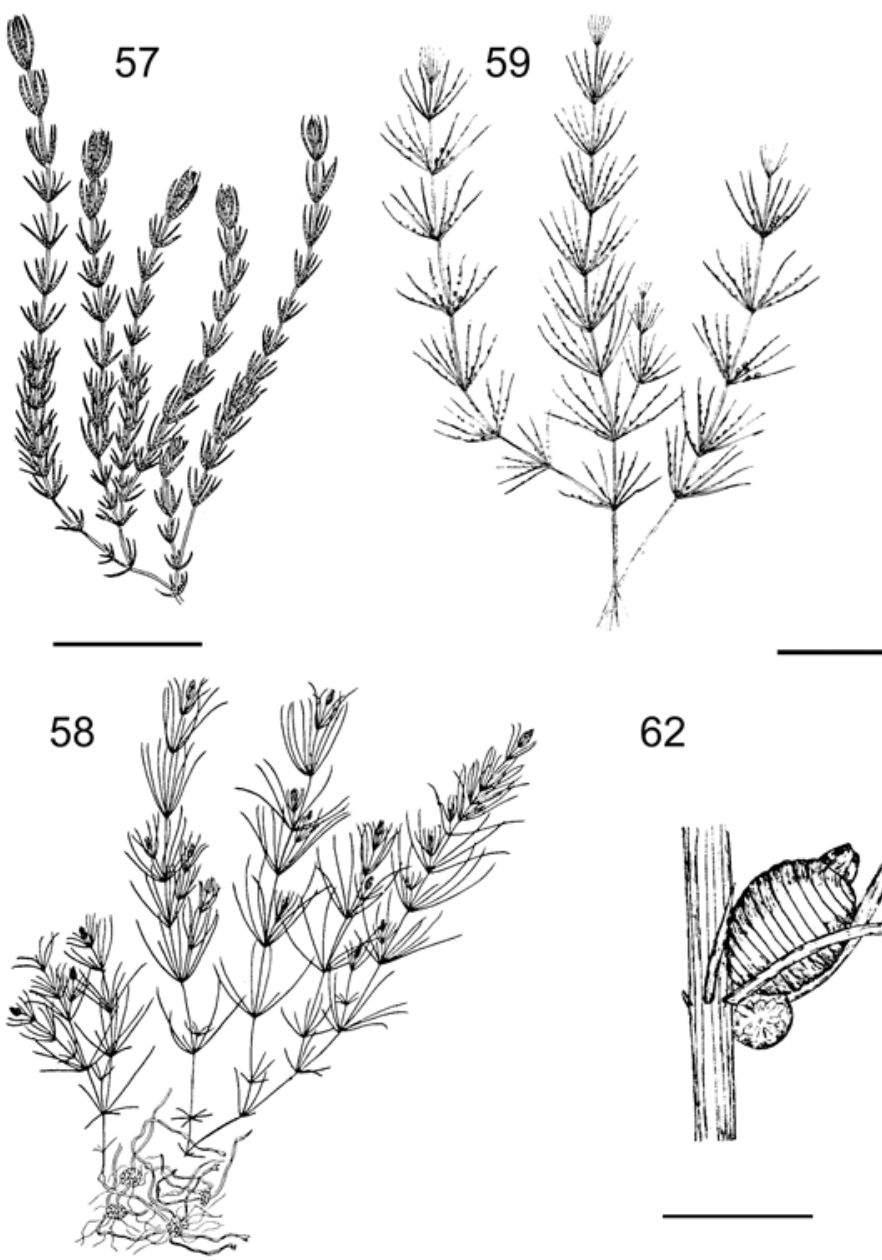

61

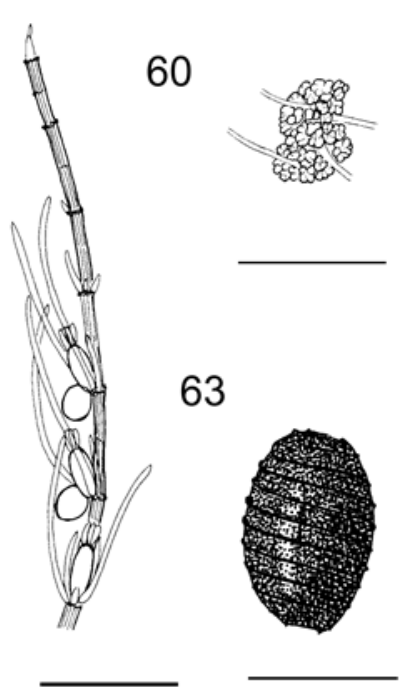

64
62

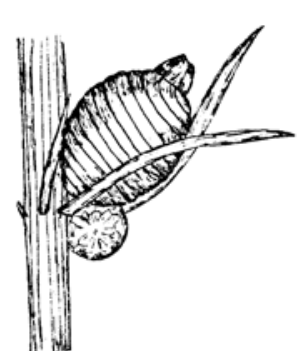

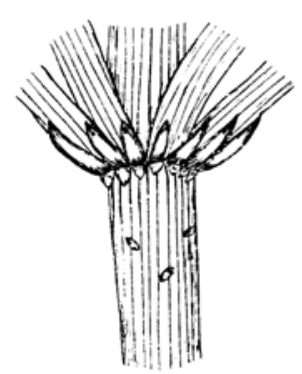

Figs 57-64. Chara delicatula [(57-58, 60-61, 63) after KrauSE (1997); (59, 62, 64) after DAMBBSKA (1964)]: (57-59) macroscopic habitus; (60) bubils; (61-62) branchlet node with oogonia and antheridia; (63) oospore; (64) internodes, stipuloides and spines. Scale bars $0.2 \mathrm{~cm}$ (Fig. 60), $0.5 \mathrm{~cm}$ (Figs 61-64) and $1 \mathrm{~cm}$ (Figs 57-59). 
Chara globularis ThuILl., Fl. Env. Paris, ed., 2: p. 472, 1799; Figs 65-75.

Synonyms: Chara fragilis Desv., Lois. Bot. Not., p. 137, 1810; Chara fragilis f. brachyphylla Mig., Rabenh. Krypt. Fl., p. 748, 1897, incl.; Chara fragilis f. normalis Mig., Rabenh. Krypt. Fl., p. 729, 1897, incl.; Chara fragilis f. brevifolia VilheLm, Mém. Soc. Roy. Sci. Boheme, p. 153, 1914, incl.; Chara fragilis f. capitatella Vilhelm, Mém. Soc. Roy. Sci. Boheme, p. 153, 1914, incl.; Chara fragilis $\mathrm{f}$. formalis VILHELM, Mém. Soc. Roy. Sci. Boheme, p. 155, 1914, incl.; Chara fragilis f. gracilior Vilhelm, Mém. Soc. Roy. Sci. Boheme, p. 156, 1914, incl.; Chara fragilis f. macrophylla Vilhelm, Mém. Soc. Roy. Sci. Boheme, p. 154, 1914, incl.; Chara fragilis f. macrostephana Vilhelm, Mém. Soc. Roy. Sci. Boheme, p. 155, 1914, incl.; Chara fragilis f. mollis Vilhelm, Mém. Soc. Roy. Sci. Boheme, p. 156, 1914, incl.; Chara fragilis f. parvula Vilhelm, Mém. Soc. Roy. Sci. Boheme, p. 156, 1914, incl.; Chara fragilis f. pseudacantha Vilhelm, Mém. Soc. Roy. Sci. Boheme, p. 155, 1914, incl.; Chara fragilis f. pusilla Vilhelm, Mém. Soc. Roy. Sci. Boheme, p. 157, 1914, incl.; Chara fragilis f. tenuis Vilhelm, Mém. Soc. Roy. Sci. Boheme, p. 152, 1914, incl. - Wood \& IMAHori, 1965: p. 162; Krause, 1997: p. 87.

The appearance varies widely (Figs 66-69). Stem: up to $9-50 \mathrm{~cm}$ tall, slender, brown to green, in generallooks quite smooth, moderatelyincrustated.

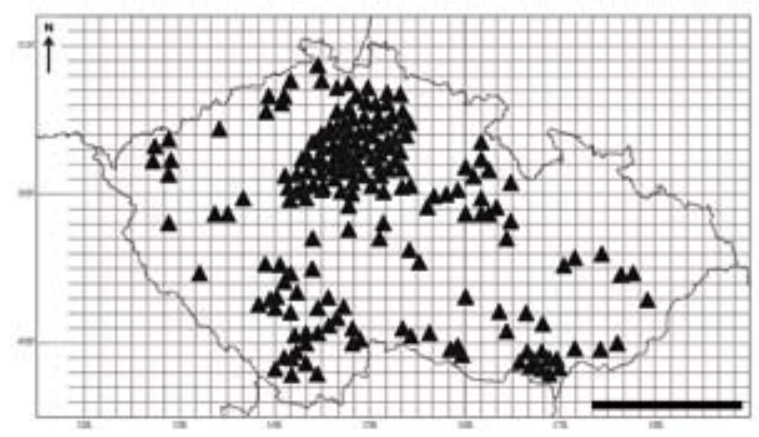

Fig. 65. Distribution of Chara globularis in the Czech Republic (scale bar $100 \mathrm{~km}$; for localities see attachment).
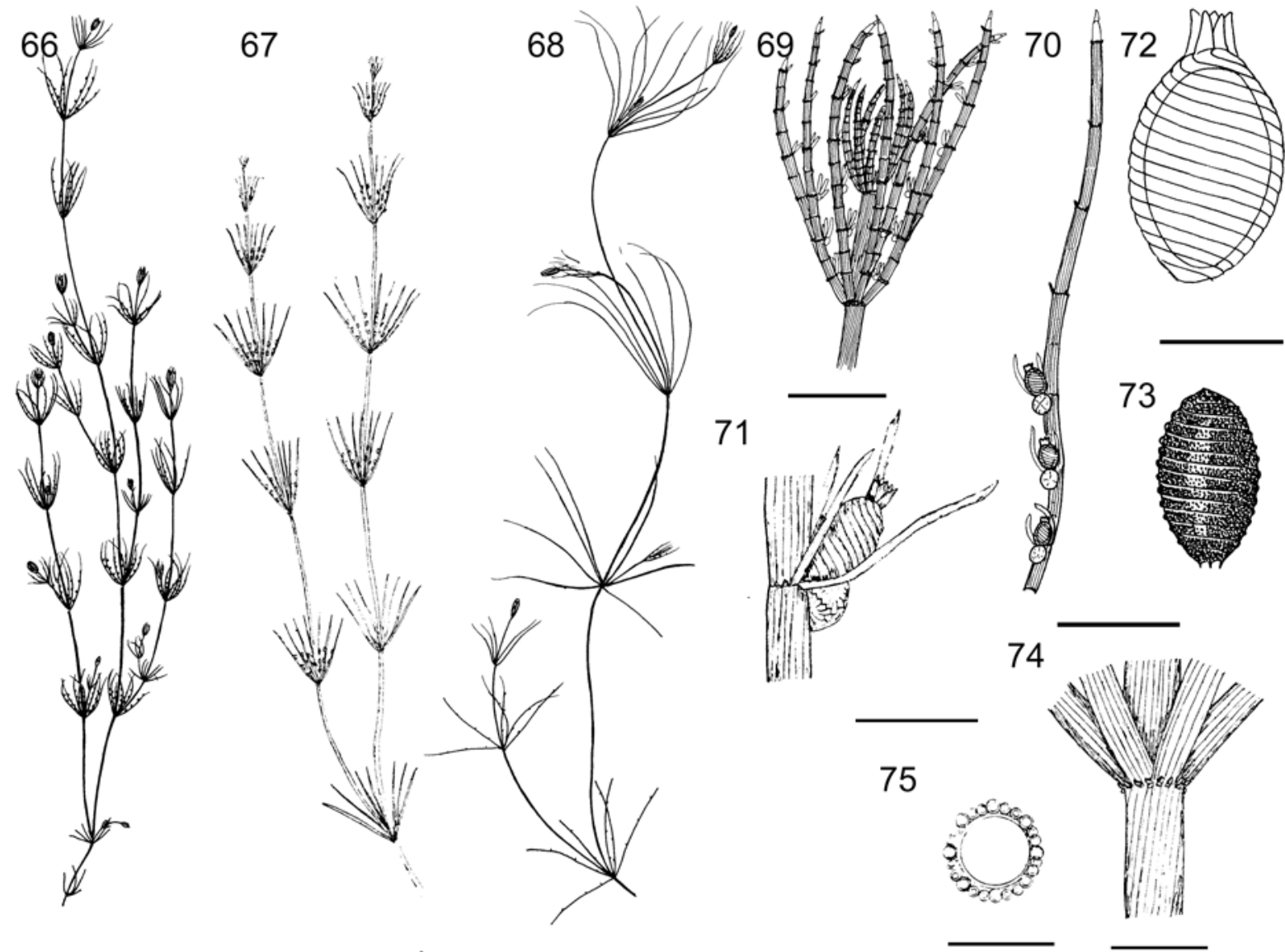

Figs 66-75. Chara globularis [(66, 68-70, 72-73) after Krause (1997); (67, 71, 74-75) after DĄMBSKA (1964)]: (66-69) macroscopic habitus; (70-71) branchlet node with oogonia and antheridia; (72) oogonium; (73) oospore; (74) internodes, stipuloides and spines; (75) internode cross-section. Scale bars $0.2 \mathrm{~cm}$ (Fig. 72), $0.5 \mathrm{~cm}$ (Figs 70-71, 73-75) and $1 \mathrm{~cm}$ (Figs 67-69). 
Cortex: triplostichous, isostichous. Spine cells and stipulodes: strongly reduced, rudimentary or globular (Figs 74-75). Internodes: firm, 1-6 times the length of the branchlets (Figs 68-69, 74). Branchlets: 6-11 with 8-12 segments in a whorl (Figs 68-69), upper 1-3 segments may be ecorticated. Terminal cells of branchlets: slightly reduced. Bracteoles: longer than the oogonium. Plants monoecious. Gametangia: solitary or conjoined at 1-3 (5) lowest branchlet nodes, without mucus. Oogonia: solitary, 530-1100 x 300-700 $\mu \mathrm{m}$ (Figs 70-72), mature oospores dark brown to black, rarely yellow or orange colour with marked stripes, papillated or granulated (Fig. 73). Antheridia: small and solitary, 300-500 $\mu \mathrm{m}$ in diameter (Figs 70-71).

Ecology: Common in stagnant shallow waters forming thick monospecific growths. It was also recorded from cold arctic and alpine biotopes.

Distribution: Worldwide, records from North America, Africa, Asia, Australia and Europe (DĄmbSKa 1964, KRAuse 1997). In Europe it has been reported from Germany, Denmark, Norway, Slovakia and Poland (Krause 1997). In the Czech Republic it is common species. It has been found in more than 300 localities (Fig. 65).

Chara gymnophylla A. BR., Flora, 18: p. 62, 1835; Figs 76-81.

Synonyms: Chara gymnophylla f. tenuis VILHeLm, Mém. Soc. Roy. Sci. Boheme, p. 108, 1914, incl. WoOd \& IMAhORI, 1965: p. 105; Krause, 1997: p. 106.

The appearance varies widely (Figs 77-78). Stem: up to 3-15 (25) cm tall, slender, brown to dark green, moderately incrusted or without incrustation. Cortex: diplostichous, aulacanthous, thylacanthous or sometimes isostichous. Spine cells: globular, shorter then axis diameter (Figs 80-81). Stipulodes: in 2 rows, short, oval and usually reduced spines (Fig. 80). Internodes: firm, corticated, 1-6 times the length of the branchlets (Fig. 80). Branchlets: 6-11 in a whorl (Fig. 78), ecorticated or with 1-2 corticated segments; segments completely ecorticated are fertile. Terminal cells of branchlets: reduced, conical or mucronate. Bracteoles: 1-2 times longer than the oogonium. Plants monoecious. Gametangia: separate, geminate or conjoined at lowest 1-3 branchlet nodes, without mucus. Oogonia: solitary or geminate, incrusted, $500-800 \times 350-525 \mu \mathrm{m}$ (Fig. 79), mature oospores brown to black colour, smooth or granulated. Antheridia: solitary, 400-
$600 \mu \mathrm{m}$ in diameter (Fig. 79).

Ecology: Not well known, recorded only from fishponds.

Distribution: Records from Africa, Asia and Europe (DAmBSKa 1964, WoOd \& IMAHORY 1965, KRAUSE 1997). In Europe it has been reported

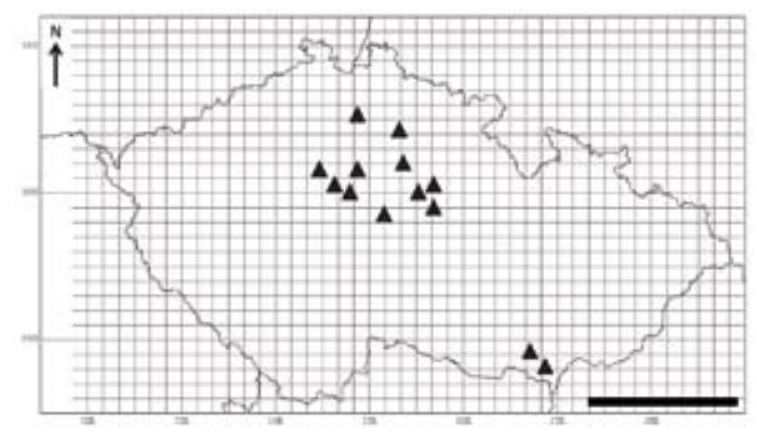

Fig. 76. Distribution of Chara gymnophylla in the Czech Republic (scale bar $100 \mathrm{~km}$; for localities see attachment).

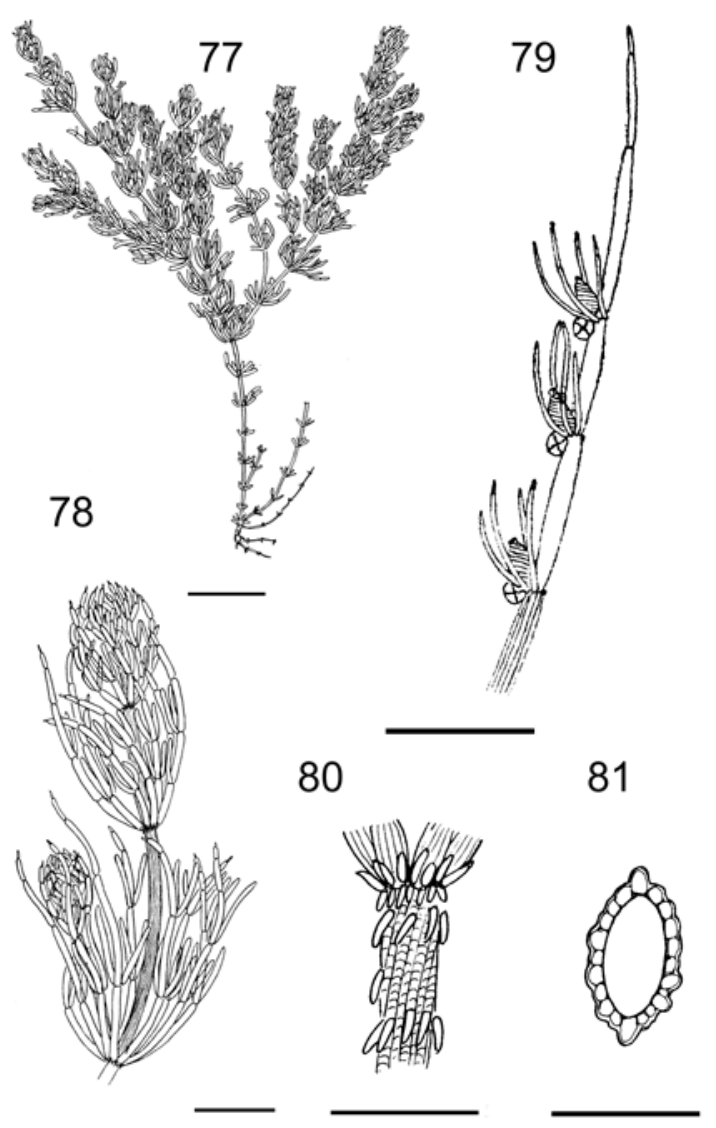

Figs 77-81. Chara gymnophylla [(77-78, 80-81) after KRAUSE (1997); (79) after DĄMBSKA (1964)]: (77-78) macroscopic habitus; (79) branchlet node with oogonia and antheridia; (80) internodes, stipuloides and spines; (81) internode crosssection. Scale bars $=0.5 \mathrm{~cm}$ (Figs 79-81) and $1 \mathrm{~cm}$ (Figs 77-78). 
from Germany, Slovakia, Portugal and from Balkans (Wood \& Imahory 1965, Krause 1997, BlAŽENČIĆ et al 2006). In the Czech Republic it has been recorded from 13 sites (Fig. 76).

Chara hispida L., Sp. Pl., 2: p. 1156, 1753; Figs 82-90.

Synonyms: Chara hispida f. equisetina Mig., Rabenh. Krypt. Fl., p. 637, 1897, incl.; Chara hispida v. longifolia A. Br. in Vilhelm, Mém. Soc. Roy. Sci. Boheme, p. 140, 1914, incl. - Wood \& IMAHORI, 1965: p. 129; KRAUSE, 1997: p. 71.

The appearance varies widely (Figs 83-84). Stem: up to 5-90 (200) cm tall, slender, grey to green, often strongly incrusted. Cortex: diplostichous, aulacanthous or isostichous. Spine cells: acute often long, 2-3 in cluster (Figs 89-90). Stipulodes: long, acuminate in 2 regular rows (Fig. 89). Internodes: firm, corticated, twisted, 1-3 (15) times the length of the branchlets (Figs 83-84, 89). Branchlets: 7-10 in a whorl (Fig. 84), 7-9 segments, upper 1-3 segments may be ecorticated. Terminal cells of branchlets: often reduced (Fig. 85). Bracteoles: 1-2 times longer than the oogonium. Plants monoecious. Gametangia: conjoined at 2-4 branchlet nodes, without mucus. Oogonia solitary, 850-1200 x
570-850 $\mu \mathrm{m}$ (Figs 86-87), mature oospores dark brown to black colour with granulate or smooth (Fig. 88). Antheridia: $400-600 \mu \mathrm{m}$ in diameter (Figs 86-87).

Ecology: Common in shallow freshwater ecosystems. Species was also recorded under ice cover.

Distribution: Concentrated in Europe (DAMBSKA 1964, KRAUSE 1997). It has been reported from Germany, Denmark, Poland, Hungary, Slovakia, Italy and Spain (Krause 1997). In the Czech Republic it has been mainly recorded from Central Bohemia, about 20 sites (Fig. 82).

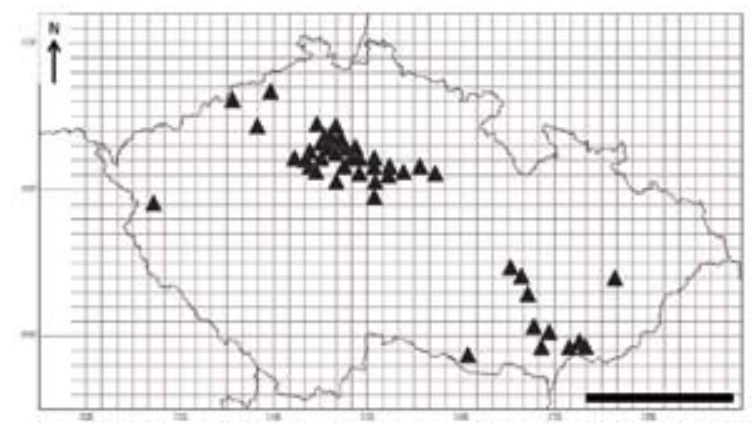

Fig. 82. Distribution of Chara hispida in the Czech Republic (scale bar $100 \mathrm{~km}$; for localities see attachment).
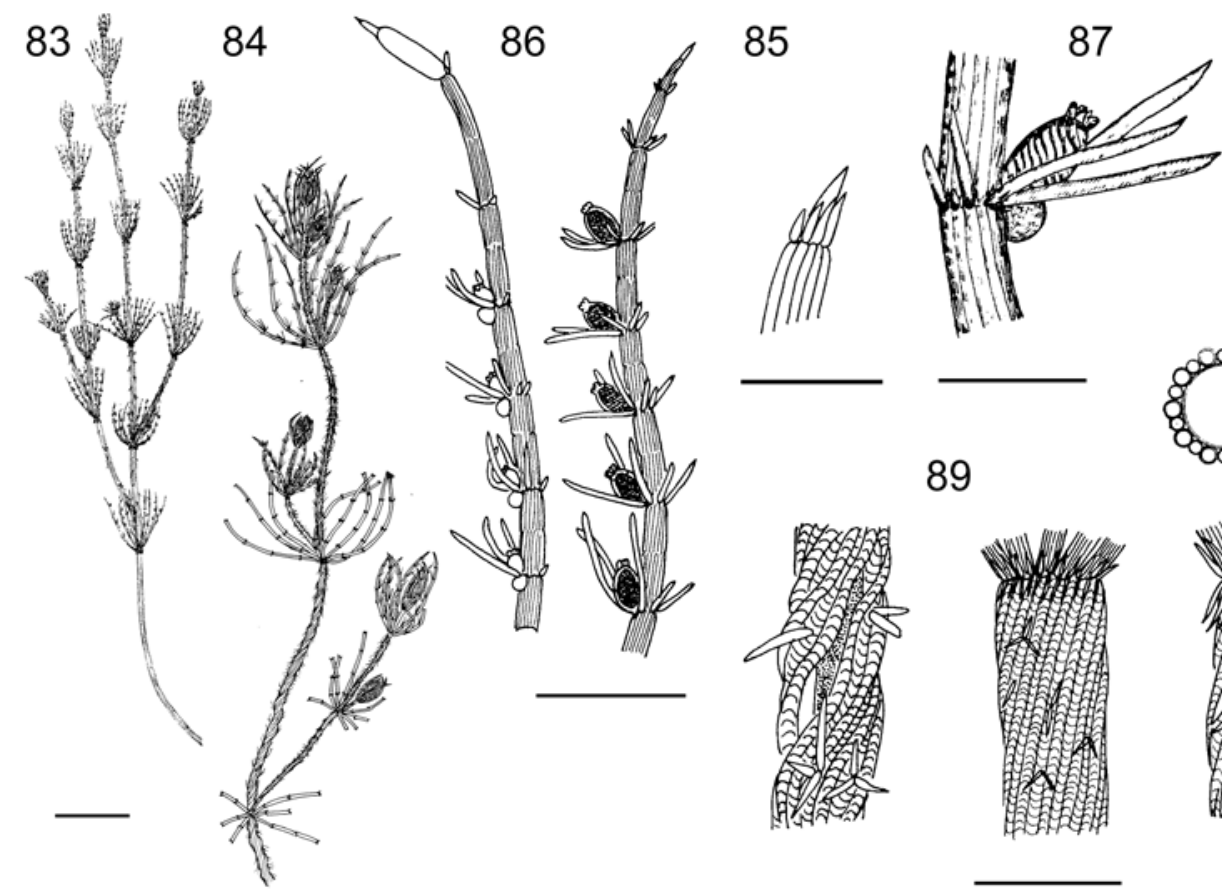

88
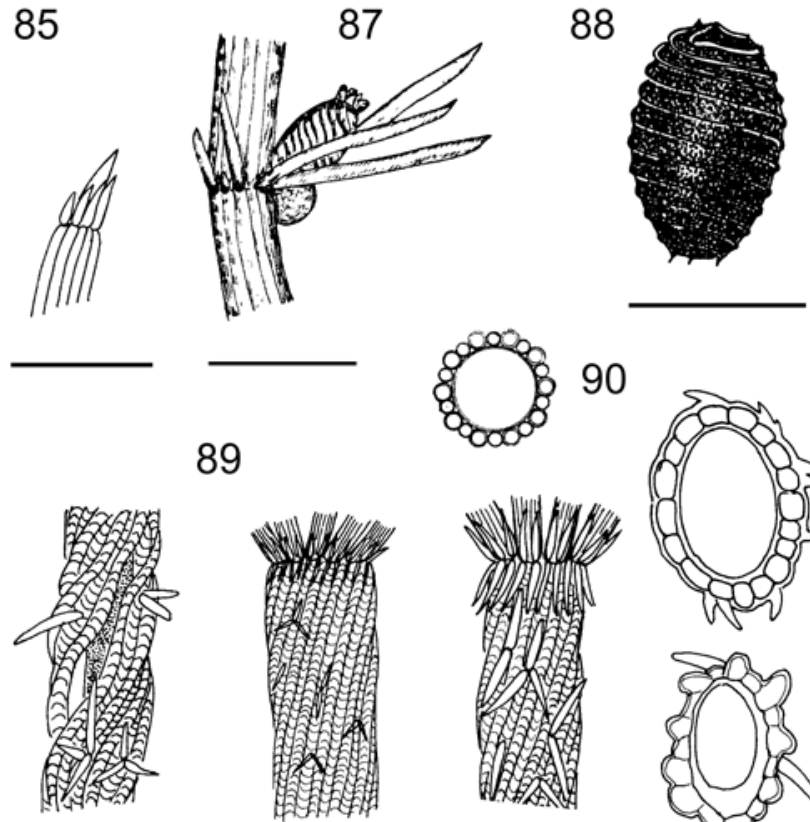

89

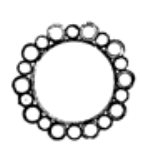

90

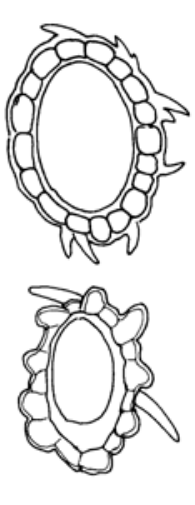

Figs 83-90. Chara hispida [(83, 87, 90) after DĄmBSKA (1964); (84-86, 88-90) after Krause (1997)]: (83-84) macroscopic habitus; (85) ends of branching; (86-87) branchlet node with oogonia and antheridia; (88) oospore; (89) internodes, stipuloides and spines; (90) internode cross-section. Scale bars $0.5 \mathrm{~cm}$ (Figs 85-90) and $1 \mathrm{~cm}$ (Figs 83-84). 
Chara intermedia A. BR., Fl. Crypt. Badensis, p. 151, 1836; Figs 91-98.

Synonyms: WoOd \& IMAHORI, 1965: p. 145 ; KRAUSE, 1997: p. 79.

The appearance varies widely (Figs 92-93). Stem: up to 4-30 (90) $\mathrm{cm}$ tall, slender, grey to dark green, sometimes reddish green, moderately incrustated. Cortex: diplostichous, tylacanthous. Spine cells: shorter than the axis diameter, often 2-3 in cluster (Figs 97-98). Stipulodes: in 2 rows, robust (Fig. 97). Internodes: firm, corticated, 2-4 times the length of the branchlets (Figs 93, 97). Branchlets: (7) 8-10 in a whorl (Fig. 93), 5-7 segments from which 1-2 segments are ecorticated. Terminal cells of branchlets: reduced and naked. Bracteoles: usually shorter than the oogonium. Plants monoecious. Gametangia: separate or conjoined at lowest 3-4 branchlet nodes, without mucus. Oogonia: solitary or geminate, incrusted, 950-1200 x 675-850 $\mu \mathrm{m}$ (Figs 94-95), mature oospores dark brown to black colour with marked stripes or smooth (Fig. 96). Antheridia: solitary, $400-500 \mu \mathrm{m}$ in diameter (Figs 94-95).
Ecology: Common in shallow waters with calcium-rich organic substrate.

Distribution: Worldwide, records from North and South America, Asia and Europe (DAMBBSKA 1964, WoOd \& IMAHORY 1965, KRAUSE 1997). In Europe it is known from Germany, Slovakia, Austria, Poland and Denmark (Wood \& ImaHory 1965, KRAUSE 1997). It has been reported from sites in the Czech Republic (Fig. 91).

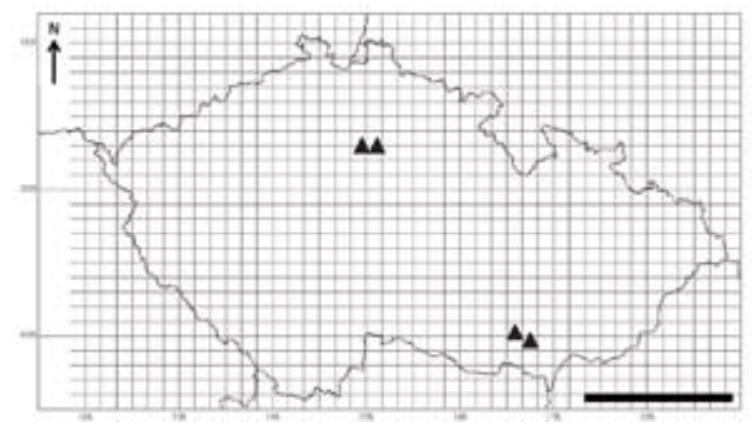

Fig. 91. Distribution of Chara intermedia in the Czech Republic (scale bar $100 \mathrm{~km}$, for localities see attachment).

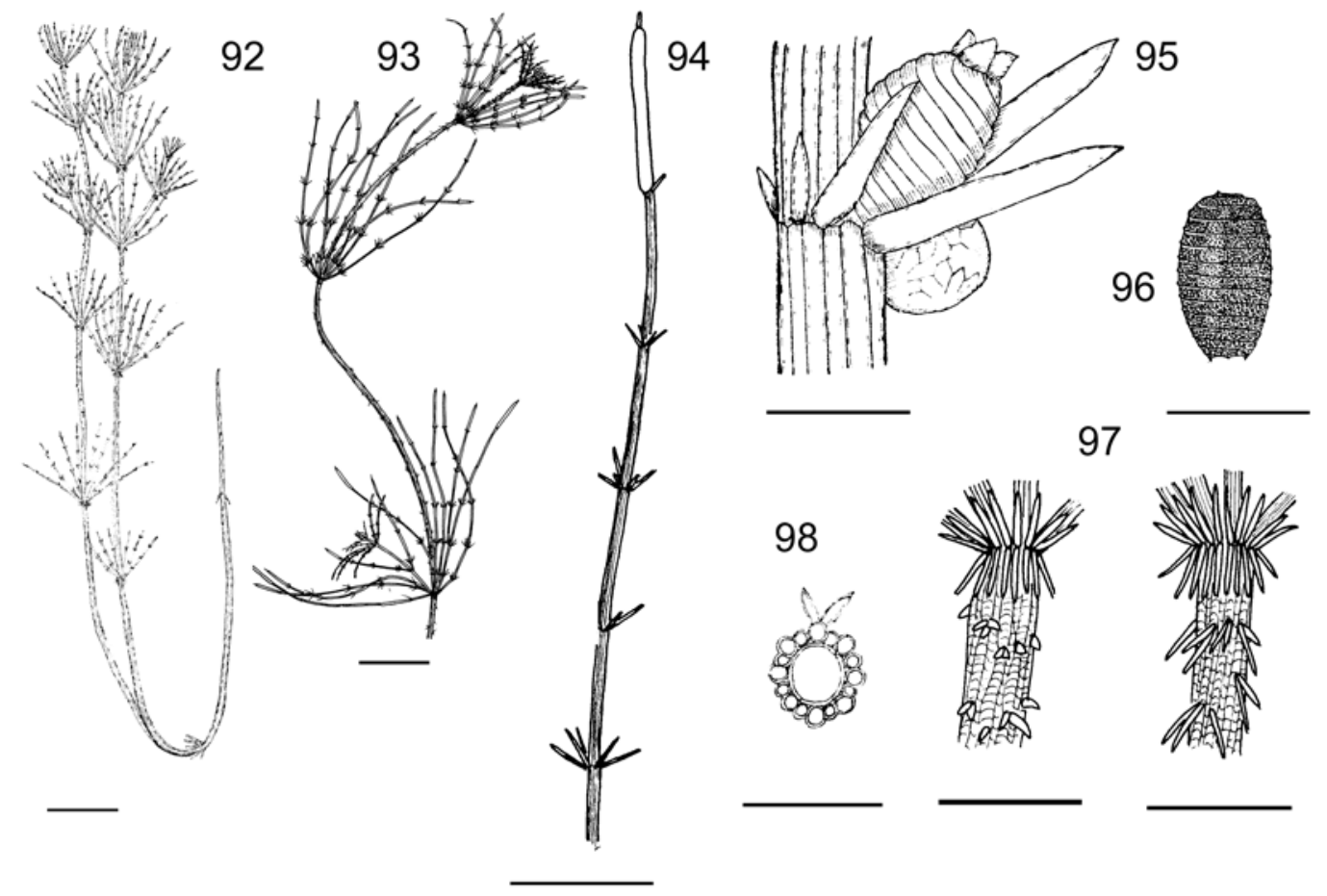

Figs 92-98. Chara intermedia [(92, 95, 98) after DAMBSKA (1964); (93-94, 96-97) after KRAUSE (1997)]: (92-93) macroscopic habitus; (94-95) branchlet node with oogonia and antheridia; (96) oospore; (97) internodes, stipuloides and spines; (98) internode cross-section. Scale bars $0.5 \mathrm{~cm}$ (Figs 94-98) and $1 \mathrm{~cm}$ (Figs 92-93). 
Chara polyacantha A. Br., Char. Exs., p. 48, 1859; Figs 99-106.

Synonyms: Wood \& IMAHORI, 1965: p. 136; KraUSE, 1997: p. 77.

Stem: up to $20-30(100) \mathrm{cm}$ tall, grey to light green, heavily incrustated (Figs 100-101). Cortex: diplostichous, tylacanthous, irregular. Spine cells: acute, dense, longer than the axis diameter, 3-4 (5) together in cluster (Figs 105106). Stipulodes long in 2 rows, acuminate (Fig. 105). Internodes: firm, corticated, 2-4 times the length of the branchlets (Figs 101, 105). Branchlets: 8-10 in a whorl (Fig. 101), the upper 2-3 segments may be ecorticated. Specimens found in the Czech Republic have short branchlets to $2 \mathrm{~cm}$ long. Terminal cells of branchlets: reduced and naked. Bract cells: 5-7, 2-3 times longer than the oogonium. Plants monoecious. Gametangia: separate or conjoined at lowest 3-4 branchlet nodes, without mucus. Oogonia solitary or geminate, incrusted, 850-1100 x 600$700 \mu \mathrm{m}$ (Figs 102-103), mature oospores black colour with marked stripes or smooth (Fig. 104). Antheridia: solitary and smaller $(250-500 \mu \mathrm{m}$ in diameter) (Figs 102-103).

Ecology: Not well known.

Distribution: Concentrated in Europe, records from Germany, Poland and Denmark, Sweden, France, Portugal and Balkans (DAmBSSKA 1964, Wood \& ImAhory 1965, Krause 1997). In the Czech Republic, this species has only been noticed from Lysá nad Labem (Fig. 99).

Chara rudis (A. Br.) A. BR. in A. BR. et Nords., Abh. K. Akad. Wiss. Berlin, p. 173, 1882; Figs 107-115.

Synonyms: WoOd \& IMAHORI, 1965: p. 144; KRAUSE, 1997: p. 126.

Stem: up to 5-50 (70) $\mathrm{cm}$ tall, slender, pale to dark green, moderately or heavily incrustated (Figs 108-110). Cortex: diplostichous, strongly aulacanthous. Spine cells: solitary or 3 in cluster (Figs 114-115). Stipulodes: long in 2 well developed rows, obtuse (Fig. 114). Internodes: firm, corticated, 1-2 times the length of the branchlets (Figs 110-114). Branchlets: 7-10 in a whorl (Fig. 110), upper 1-3 segments may be ecorticated. Terminal cells of branchlets: sharp, forming tiny terminal corona or mucro. Bract cells: 5-6, shorter than oogonium. Plants monoecious. Gametangia: conjoined at all

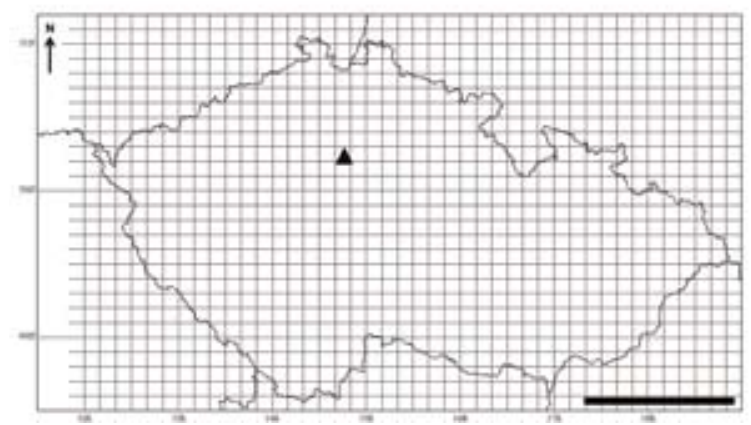

Fig. 99. Distribution of Chara polyacantha in the Czech Republic (scale bar $100 \mathrm{~km}$, for localities see attachment).
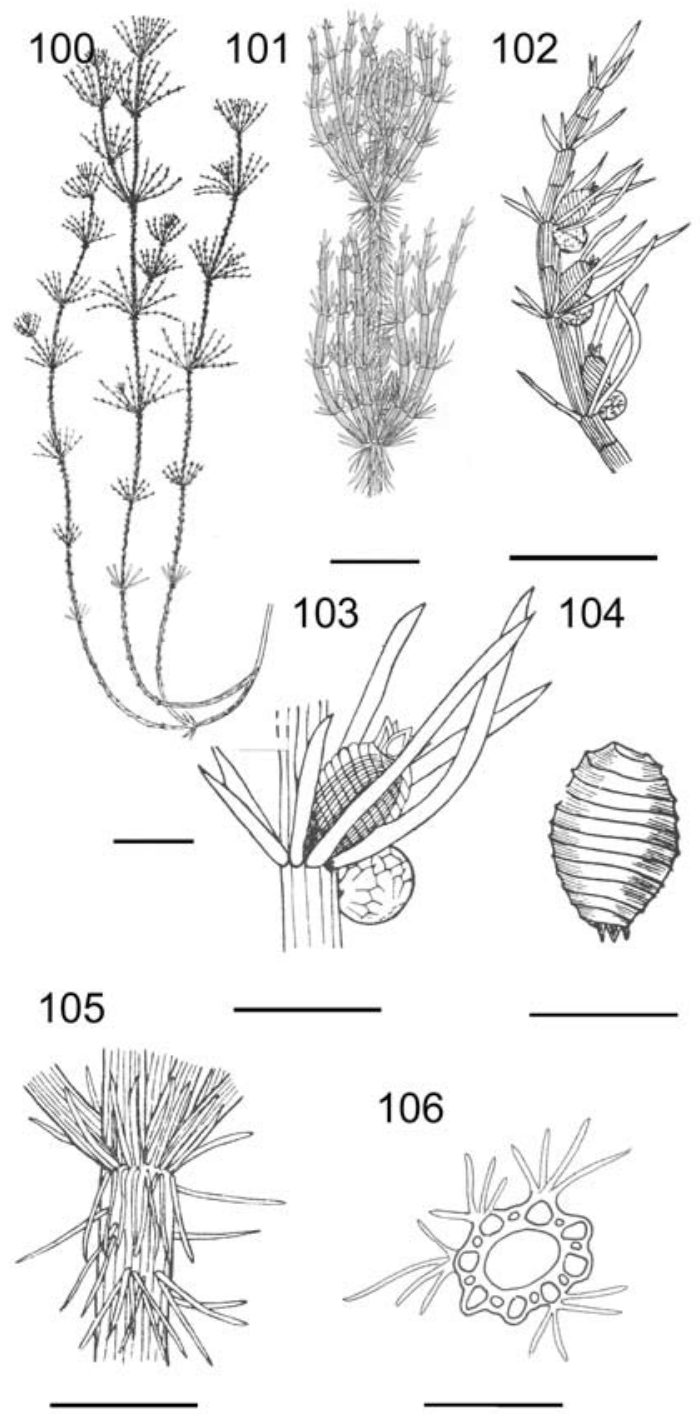

Figs 100-106. Chara polyacantha $[(100,102-104,106)$ after DAmBSKa (1964); (101, 105) after KRAUSE (1997)]: (100-101) macroscopic habitus; (102-103) branchlet node with oogonia and antheridia; (104) oospore; (105) internodes, stipuloides and spines; (106) internode cross-section. Scale bars $0.5 \mathrm{~cm}$ (Figs 102-106) and $1 \mathrm{~cm}$ (Figs 100-101). 
branchlet nodes except for the distal one, without mucus. Oogonia: solitary, incrusted, 900-1050 x 600-630 $\mu \mathrm{m}$ (Figs 111-112), mature oospores dark brown colour with marked stripes (Fig. 113). Antheridia: small, about $400 \mu \mathrm{m}$ (Figs 111112).

Ecology: Common in calcium-rich shallow waters and occasionally in brackish ecosystems.

Distribution: Records from Europe and Asia (Dambska 1964, Wood \& Imahory 1965, Krause 1997). From Europe it has been reported from Germany, Slovakia, Austria, Denmark, Poland,

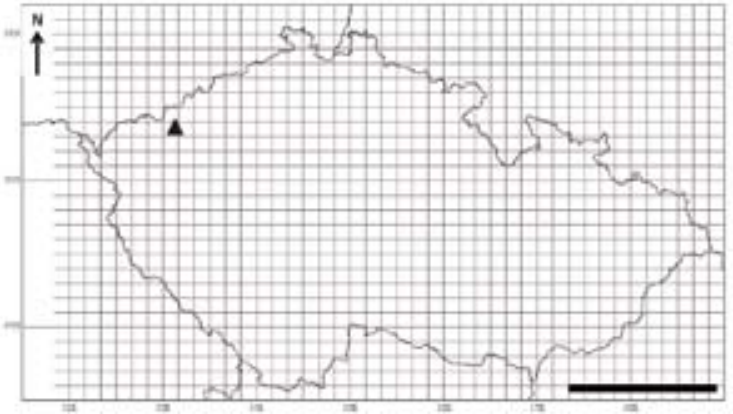

Fig. 107. Distribution of Chara rudis in the Czech Republic (scale bar $100 \mathrm{~km}$; for localities see attachment).

France and Switzerland (WoOd \& IMAHORY 1965, KRAUSE 1997). There is only one locality in the Czech Republic (Fig. 107).
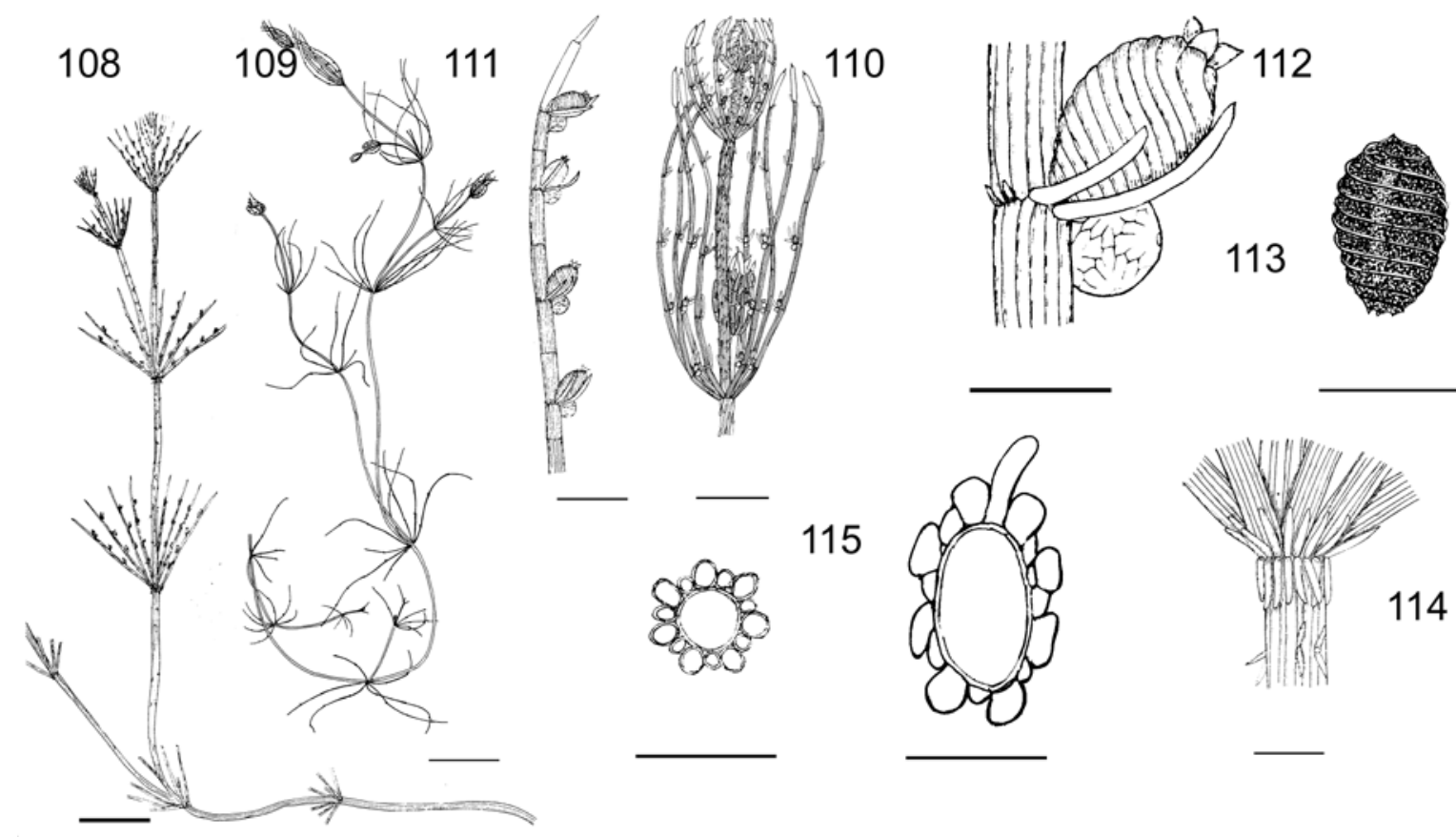

Figs 108-115. Chara rudis [(108, 110, 112, 114-115) after DĄMBSKA (1964); (109, 111, 113, 115) after KRAUSE (1997)]: (108110) macroscopic habitus; (111-112) branchlet node with oogonia and antheridia; (113) oospore; (114) internodes, stipuloides and spines; (115) internode cross-section. Scale bars $0.5 \mathrm{~cm}$ (Figs 111-115) and $1 \mathrm{~cm}$ (Figs 108-110).

Chara tomentosa L., Sp. P1., 2: p. 1156, 1753; Figs 116-125.

Synonyms: Chara ceratophylla WALLROTH, Ann. Bot., p. 192, 1815. - WOOD \& IMAHORI, 1965: p. 66; KRAUSE, 1997: p. 68.

The appearance varies widely (Figs 117-118). Stem: up to $10-60 \mathrm{~cm}$ tall, robust, grey, green to brown or red (especially young plants), moderately to heavily encrusted. Cortex: diplostichous, tylacanthous or isostichous, sometimes irregular triplostichous. Spine cells: solitary or geminate, variable (Figs 124-125). Stipulodes: in 2-3 well developed rows, ovoid or acuminate (Fig. 124). Internodes: firm, cortex spiral, 1-3 times the length of the branchlets (Figs 118, 124). Branchlets: short, 6-8 in a whorl (Fig. 118), 4-5 segments, upper 1-3 segments may be ecorticated and robust. Terminal cells of branchlets: reduced (Fig. 123). Bract cells: well developed, longer than the gametangia, ovoid, acuminate. Plants dioecious. Gametangia: on separate plants, rarely conjoined at 2-3 lowest branchlet nodes, without 
mucus. Oogonia: solitary, rarely geminate (Figs 119-120), 750-1050 x 675-800 $\mu \mathrm{m}$, mature oospores dark brown colour with marked stripes (Fig. 122). Antheridia: solitary and large, 900$1500 \mu \mathrm{m}$ in diameter (Figs 119-121).

Ecology: Large fish ponds, occasionally from marshes.

Distribution: Worldwide, records from North and South America, Africa, Asia, Europe (DAmBSKA 1964, Wood \& Imahory 1965, Krause 1997). In Europe it has been reported from Germany, Denmark, Hungary, Spain, Poland, France,

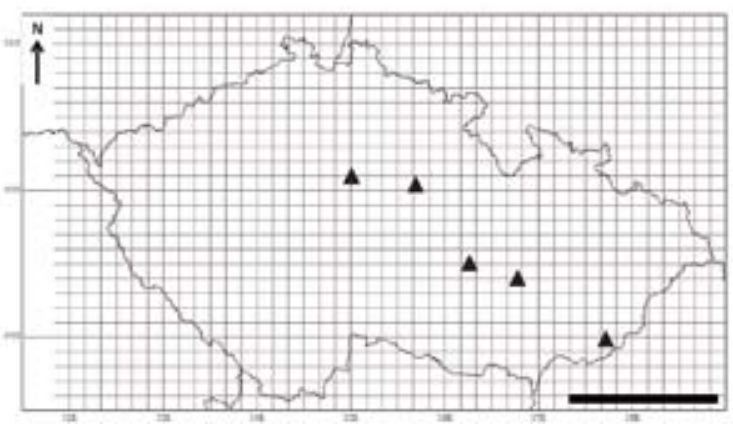

Fig. 116. Distribution of Chara tomentosa in the Czech Republic (scale bar $100 \mathrm{~km}$; for localities see attachment). Norway, Sweden, Finland and Balkans (KrauSE 1997). There have been local sightings (5 localities) also in the Czech Republic (Fig. 116).
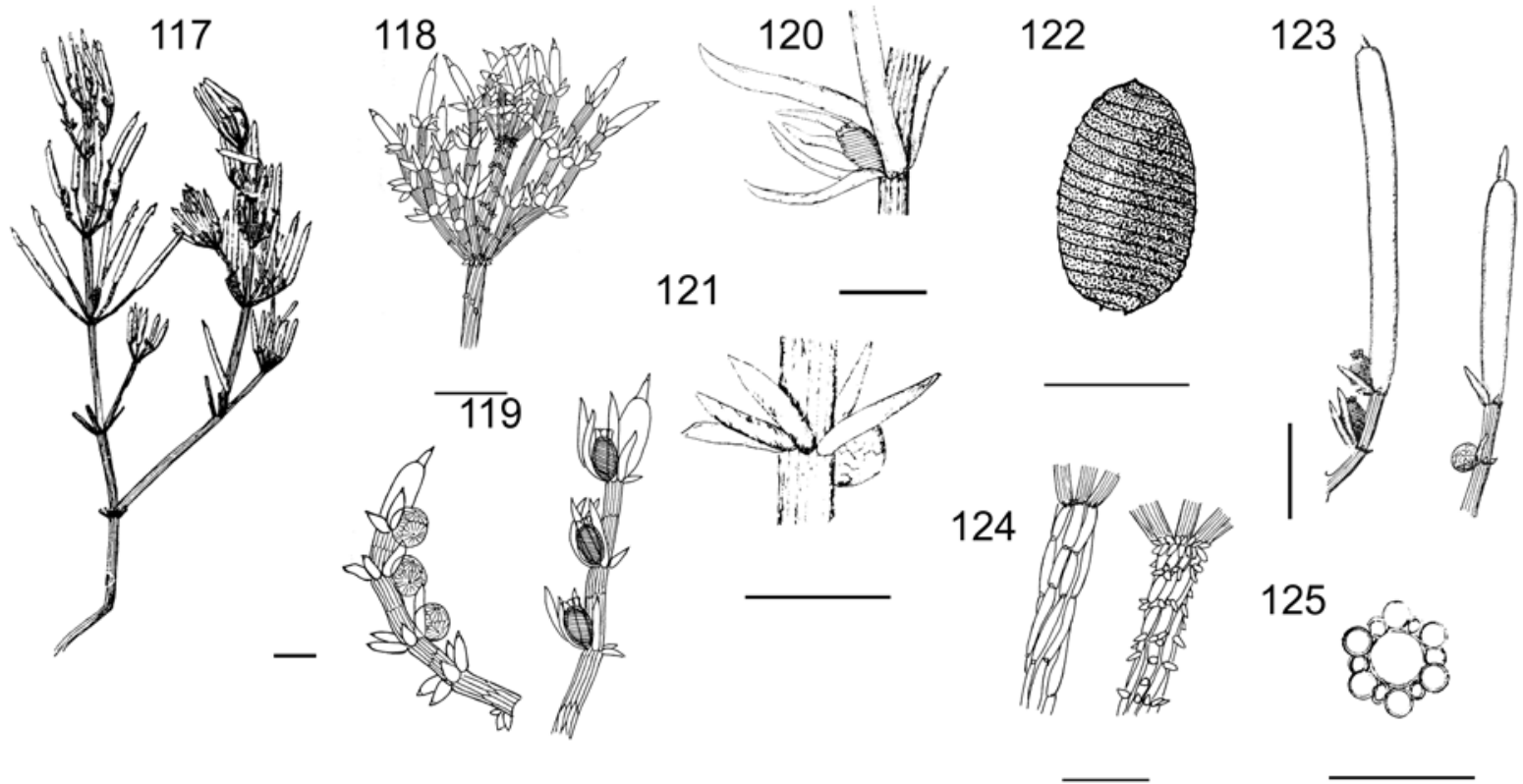

Figs 117-125. Chara tomentosa [(117, 120-121, 123, 125) after DĄMBSKA (1964); (118-119, 122, 124) after KRAUSE (1997)]: (117-118) macroscopic habitus; (119-121) branchlet node with oogonia and antheridia; (122) oospore; (123) ends of cells; (124) internodes, stipuloides and spines; (125) internode cross-section. Scale bars $=0.5 \mathrm{~cm}$ (Figs 119-125) and $1 \mathrm{~cm}$ (Figs 117-118).

Chara vulgaris L., Sp. P1., 2: p. 1156, 1753; Figs $126-133$.

Synonyms: Chara foetida A. BR., Esquisse. Monogr., p. 354, 1834; Chara foetida f. longibracteata Mig., Rabenh. Krypt. Fl., p. 567, 1897, incl.; Chara foetida f. brachyphylla Mig., Rabenh. Krypt. Fl., p. 578, 1897, incl.; Chara foetida f. brevifolia Mig., Rabenh. Krypt. Fl., p. 580, 1897, incl.; Chara foetida f. densa Mig., Rabenh. Krypt. Fl., p. 572, 1897, incl.; Chara foetida f. macroteles Mig., Rabenh. Krypt. Fl., p. 571, 1897, incl.; Chara foetida f. microteles MIG., Rabenh. Krypt. Fl., p. 599, 1897, incl.; Chara foetida f. normalis MIG.,
Rabenh. Krypt. Fl., p. 567, 1897, incl.; Chara foetida f. pseudocontraria Mig., Rabenh. Krypt. Fl., p. 578, 1897, incl.; Chara foetida f. pusilla Mig., Rabenh. Krypt. Fl., p. 584, 1897, incl.; Chara foetida f. rudis Mig., Rabenh. Krypt. Fl., p. 602, 1897, incl.; Chara foetida f. subgymnophylla Mig., Rabenh. Krypt. Fl., p. 603, 1897, incl.; Chara foetida f. bohemica Vilhelm, Mém. Soc. Roy. Sci. Boheme, p. 118, 1914, incl.; Chara foetida f. brevispina VilHelm, Mém. Soc. Roy. Sci. Boheme, p. 128, 1914, incl.; Chara foetida f. canescens Vilhelm, Mém. Soc. Roy. Sci. Boheme, p. 116, 1914, incl.; Chara foetida f. capitulifera VIlHeLm, 
Mém. Soc. Roy. Sci. Boheme, p. 113, 1914, incl.; Chara foetida f. condensata A. BR. in VILHELM, Mém. Soc. Roy. Sci. Boheme, p. 117, 1914, incl.; Chara foetida f. conglobata Vilhelm, Mém. Soc. Roy. Sci. Boheme, p. 130, 1914, incl.; Chara foetida f. elongata A. BR. in Vilhelm, Mém. Soc. Roy. Sci. Boheme, p. 125, 1914, incl.; Chara foetida f. flexiloides Vilhelm, Mém. Soc. Roy. Sci. Boheme, p. 112, 1914, incl.; Chara foetida f. gymnoteles Vilhelm, Mém. Soc. Roy. Sci. Boheme, p. 129, 1914, incl.; Chara foetida f. humilis VILHeLm, Mém. Soc. Roy. Sci. Boheme, p. 111, 1914, incl.; Chara foetida f. laxior Vilhelm, Mém. Soc. Roy. Sci. Boheme, p. 131, 1914, incl.; Chara foetida f. macropyrena Vilhelm, Mém. Soc. Roy. Sci. Boheme, p. 127, 1914, incl.; Chara foetida f. micracantha VILHELM, Mém. Soc. Roy. Sci. Boheme, p. 127, 1914, incl.; Chara foetida f. microsperma Vilhelm, Mém. Soc. Roy. Sci. Boheme, p. 132, 1914, incl.; Chara foetida f. paludosa Vilhelm, Mém. Soc. Roy. Sci. Boheme, p. 114, 1914, incl.; Chara foetida f. pratensis VILHELM, Mém. Soc. Roy. Sci. Boheme, p. 112, 1914, incl.; Chara foetida f. prolifera Vilhelm, Mém. Soc. Roy. Sci. Boheme, p. 115, 1914, incl.; Chara foetida f. pseudocondensata Vilhelm, Mém. Soc. Roy. Sci. Boheme, p. 121, 1914, incl.; Chara foetida f. rarispina Vilhelm, Mém. Soc. Roy. Sci. Boheme, p. 128, 1914, incl.; Chara foetida f. rivularis Vilhelm, Mém. Soc. Roy. Sci. Boheme, p. 115, 1914, incl.; Chara foetida f. saxatilis VILHELM, Mém. Soc. Roy. Sci. Boheme, p. 129, 1914, incl.; Chara foetida f. subrudis Vilhelm, Mém. Soc. Roy. Sci. Boheme, p. 129, 1914, incl.; Chara foetida f. tenuis Vilhelm, Mém. Soc. Roy. Sci. Boheme, p. 130, 1914, incl.; Chara foetida f. turfosa Vilhelm, Mém. Soc. Roy. Sci. Boheme, p. 127, 1914, incl.; Chara foetida f. uliginosa Vilhelm, Mém. Soc. Roy. Sci. Boheme, p. 130, 1914, incl. - WOOD \& IMAHORI, 1965: p. 73; Krause, 1997: p. 81.

Chara vulgaris is highly polymorphic (Figs 127-128). Stem: up to 5-70 cm tall, slender, grey to dark green, moderately to heavily encrusted. Cortex: diplostichous, aulacanthous or isostichous. Spine cells: variable, solitary or geminate, rudimentary, papilous or elongated to the axis diameter (Figs 132-133). Stipulodes: in 2 rows, variable (Fig. 132). Internodes: firm, corticated, 1-6 times the length of the branchlets (Figs 128, 132). Branchlets: 6-10 in a whorl (Fig. $128)$, corticated or partly ecorticated, often upper 2-3 segments may be ecorticated. Terminal cells of branchlets: variable tapered, conical, blunt or sharp, rarely forming mucro or reduced. Bract cells: often well developed, variable in length. Plants monoecious. Gametangia: conjoined at 1-4 branchlet nodes, without mucus. Oogonia: solitary or geminate, 500-1100 x (280) 335-525
(660) $\mu \mathrm{m}$ (Figs 129-130), mature oospores dark brown or black colour with stripes (Fig. 131). Antheridia: small and solitary, up to $500 \mu \mathrm{m}$ in diameter (Figs 129-130).

Ecology: Common in all types of freshwaters, especially in antropogenic reservoirs, ocasionally in brackish waters.

Distribution: Worldwide, records from South America, Africa, Asia, Europe rarely on remote oceanic islands (DĄMBSKA 1964, WoOD \& IMAHORY 1965, Krause 1997). In Europe it has been very common reported from Germany, Hungary, Slovakia, Poland, Spain, France, Sweden and Norway (Wood \& Imahory 1965). In the Czech Republic it is common species, in more than 300 localities (Fig. 126).

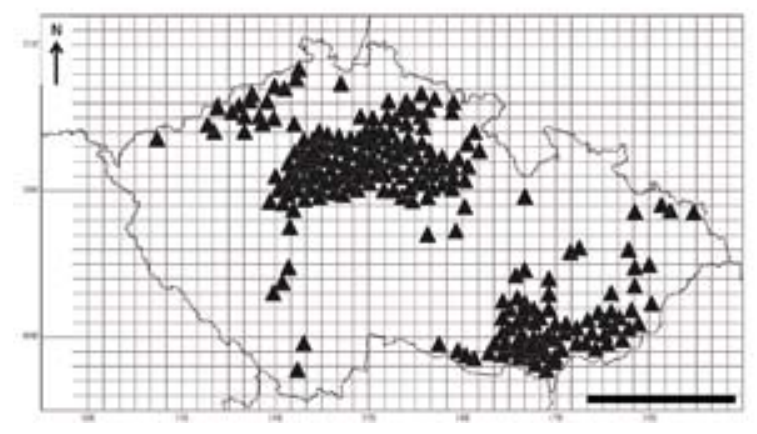

Fig. 126. Distribution of Chara vulgaris in the Czech Republic (scale bar $100 \mathrm{~km}$; for localities see attachment).

Nitella batrachosperma (REICH.) A. BR., Neue Denkschr. Schweiz. Ges. Naturw., 10: p. 10, 1847; Figs 134-141.

Synonyms: Wood \& IMAHori, 1965: p. 616; Krause, 1997: p. 158.

Stem: up to 3-7 (15) cm tall, tinny and delicate, pale to dark green, whorls concentrated in upper part, without incrustation (Figs 135-137). Internodes: very slender, 1-4 times the length of the branchlets (Fig. 135). Branchlets: 6-8 in a whorl (Fig. 137), 1-3 divided, fertile 1 or 3-furcated, sterile similar to fertile. Dactyls: 2-celled, basal cell with rounded apex, end-cells conical forming a spear (mucro) (Fig. 141). Plants monoecious. Gametangia: conjoined at all branchlet nodes without first, without mucus. Oogonia: solitary, 345-450 x 285-350 $\mu \mathrm{m}$ (Figs 138-139), mature oospores yellowish or reddish brown, dark brown to black colour with marked stripes and granulate membrane (Fig. 140). Antheridia: solitary and 


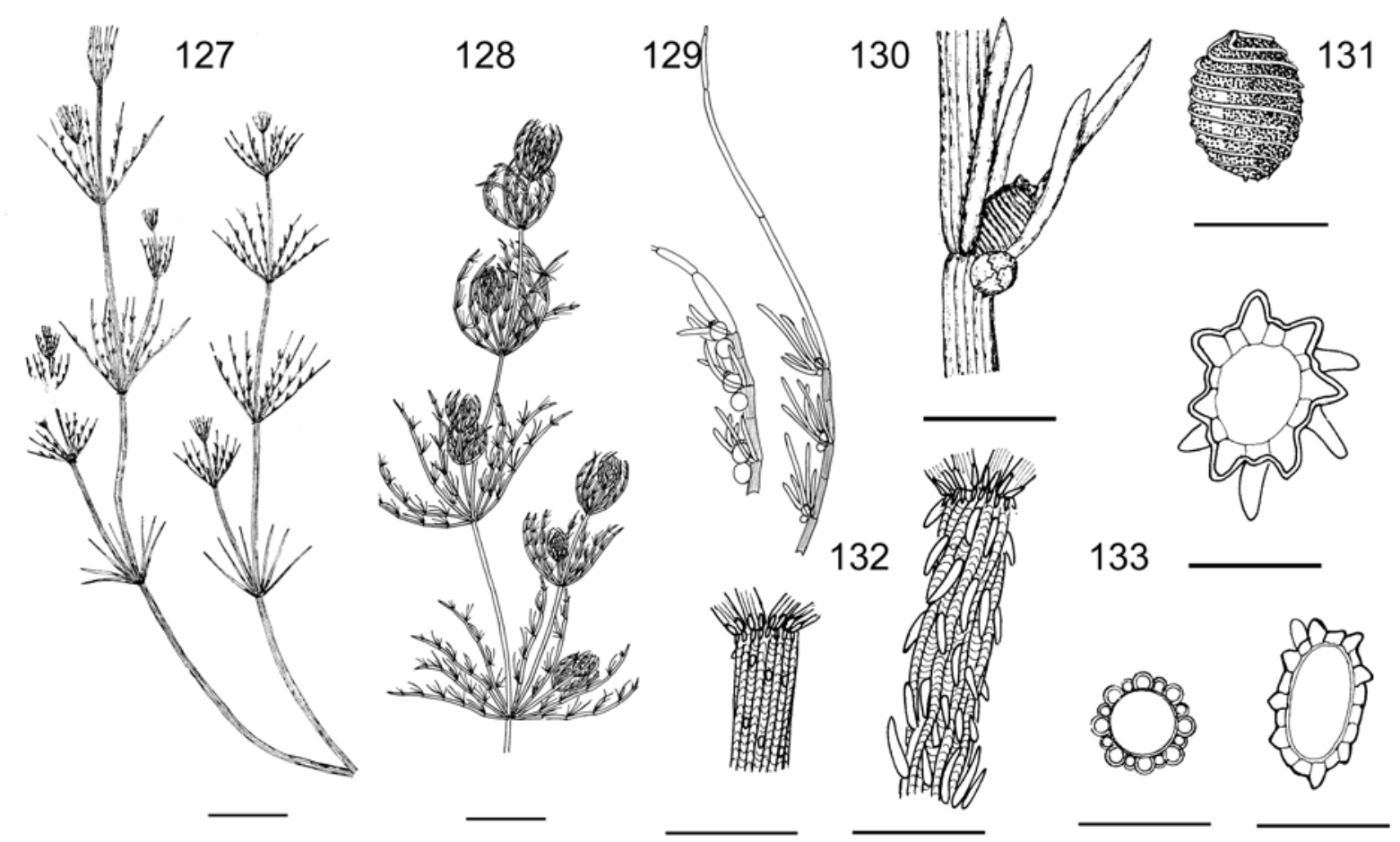

Figs 127-133. Chara vulgaris [(127, 130, 133) after DAMBSKA (1964); (128-129, 131, 133) after KRAUSE (1997)]: (127-128) macroscopic habitus; (129-130) branchlet node with oogonia and antheridia; (131) oospore; (132) internodes, stipuloides and spines; (133) internode cross-section. Scale bars $0.5 \mathrm{~cm}$ (Figs 129-133) and $1 \mathrm{~cm}$ (Figs 127-128).

small, up to $250 \mu \mathrm{m}$ in diameter (Figs 138-139). Ecology: Not well known, records only from small ponds.

Distribution: Worldwide, records from North America, Australia, Africa, Asia and Europe (DAmBsKa 1964, Wood \& IMAHORY 1965). In Europe it has been reported to be rare species from Finland, Hungary, Germany, Spain, France, Slovakia, Portugal and Poland (Krause 1997). There have been local sightings (10 sites) also in the Czech Republic (Fig. 134).

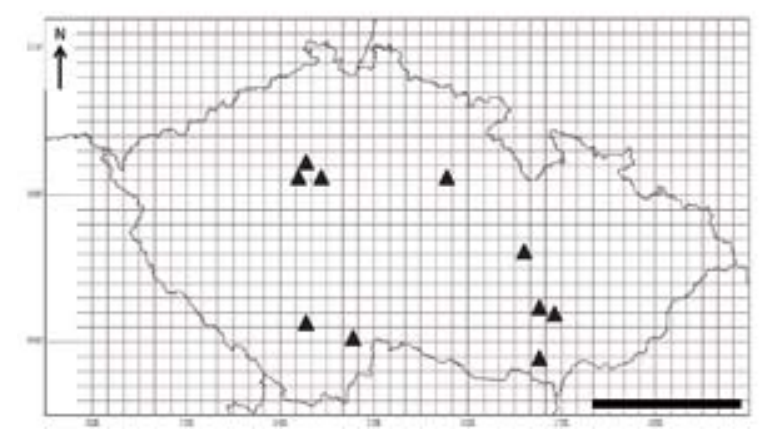

Fig. 134. Distribution of Nitella batrachosperma in the Czech Republic (scale bar 100 km; for localities see attachment).
Nitella capillaris (KROK.) J. Groves et BullockWebster, Brit. Char., p. 9, 1847; Figs 142-150.

Synonyms: WoOd \& IMAHORI, 1965: p. 417; Krause, 1997: p. 142.

The appearance varies widely (Figs 143-145). Stem: up to 10-20 (40) cm tall, slender, delicate, grey to green, slightly incrustated, with thicker mucus. Internodes: 1-2 times the length of the branchlets, slender, variable. Branchlets: 6-9 fertile and 6 sterile in a whorl, forming small dense clusters (Fig. 144), fertile 1-furcated, sterile similar to fertile. Dactyls: 1-celled, conical, blunt or acuminate (Fig. 150). Plants dioecious. Gametangia: separate plants, geminate or aggreagate at the fertile branchlet nodes, with mucus, in small heads. Oogonia: $2-3$ or solitary, 465-575 x 425-450 $\mu \mathrm{m}$ (Figs 146, 148), mature oospores pale to dark brown or black colour with marked stripes (Fig. 149). Antheridia: solitary and small up to $600 \mu \mathrm{m}$ in diameter, with mucus (Fig. 147). The fertile plants are found in spring. Ecology: Common in shallow waters (ponds, ditches, pools and peatlands).

Distribution: Records from Africa, Asia and Europe (DAMBSKA 1964, WoOD \& IMAHORY 1965). In Europe it has been reported as common from 


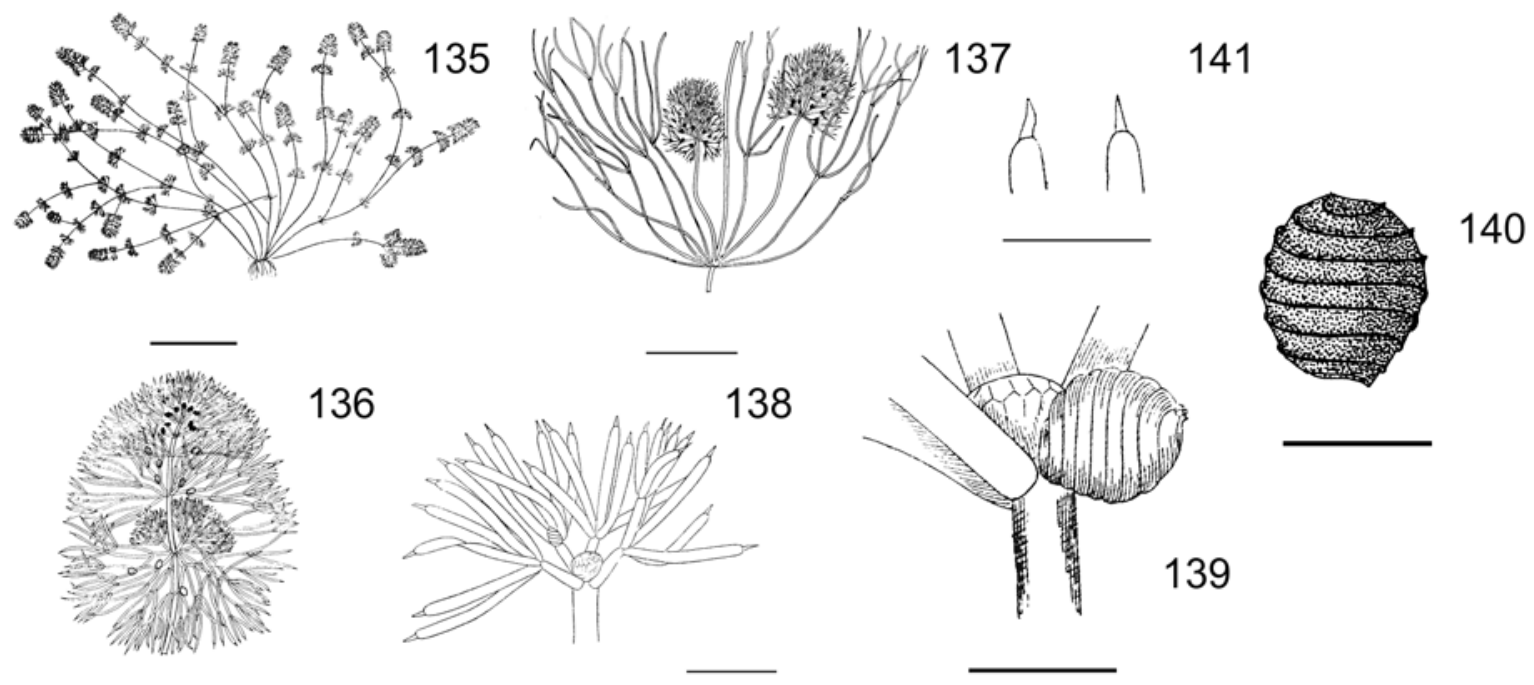

Figs 135-141. Nitella batrachosperma [(135, 138-141) after DĄmBSKa (1964); (136-137, 140) after KRAUSE (1997)]: (135137) macroscopic habitus; (138-139) branchlet node with oogonia and antheridia; (140) oospore; (141) ends of branching. Scale bars $0.5 \mathrm{~cm}$ (Figs 140-141) and $1 \mathrm{~cm}$ (Figs 135-139).

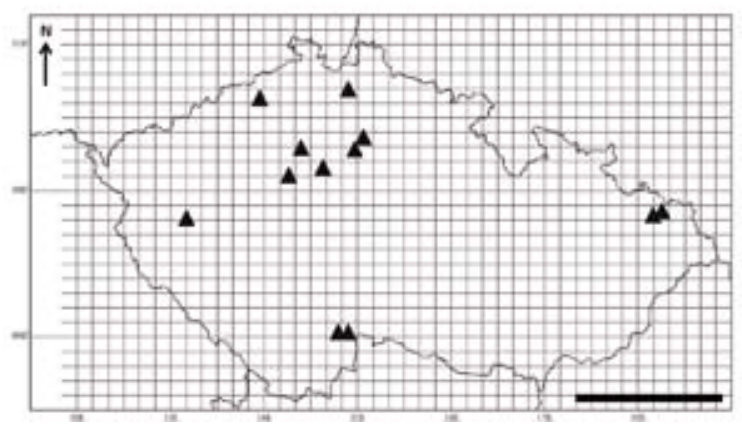

Fig. 142. Distribution of Nitella capillaris in the Czech Republic (scale bar $100 \mathrm{~km}$; for localities see attachment).

$\overrightarrow{\text { Figs } 143-150 . \text { Nitella capillaris }[(143,150) \text { after DĄMBSKA }}$ (1964); (144-149) after KRAUSE (1997)]: (143-145) macroscopic habitus; (146-148) branchlet node with oogonia and antheridia; (149) oospore; (150) ends of branching. Scale bars $0.5 \mathrm{~cm}$ (Figs 147-150) and $1 \mathrm{~cm}$ (Figs 143-146).

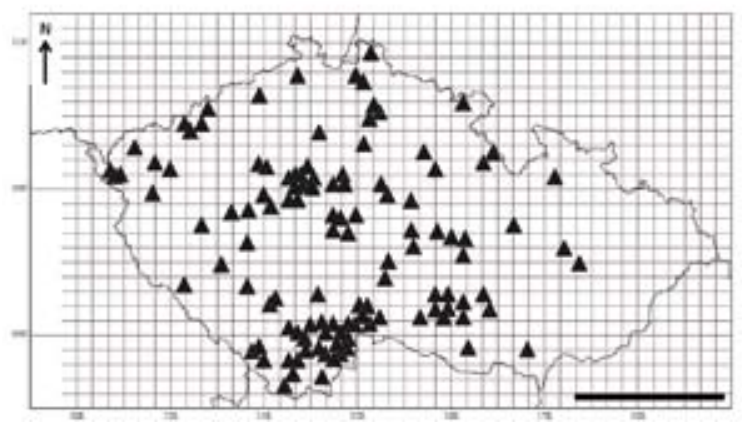

Fig. 151. Distribution of Nitella flexilis in the Czech Republic (scale bar $100 \mathrm{~km}$; for localities see attachment).

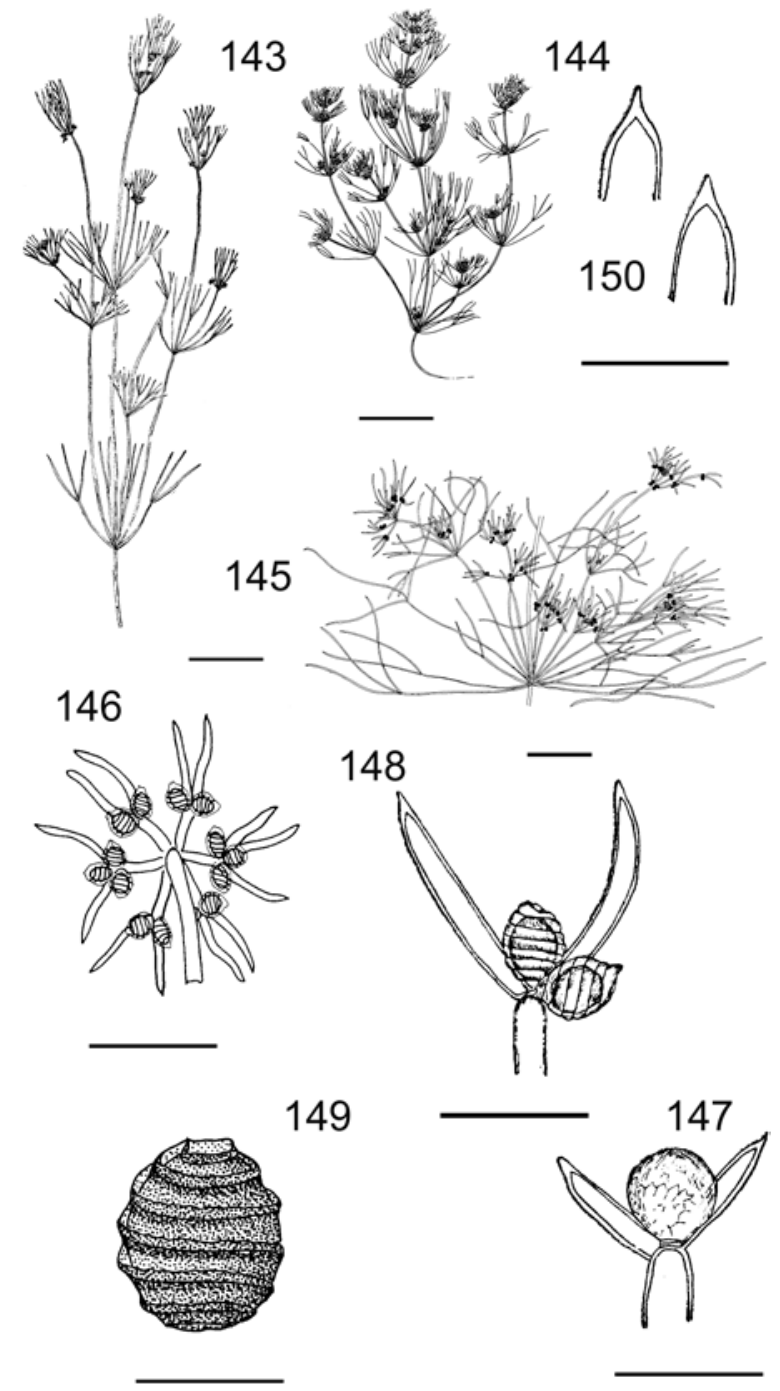



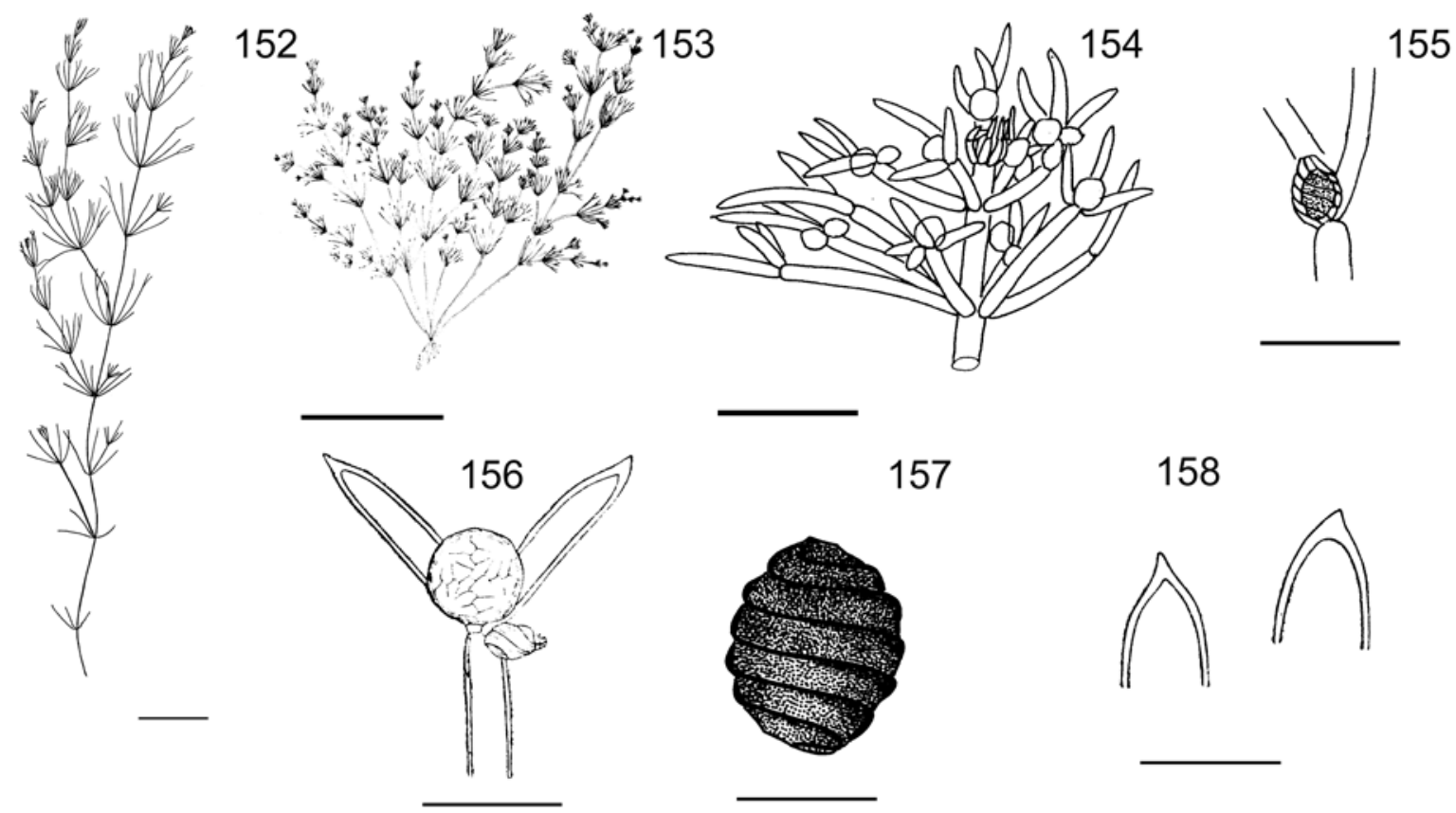

Figs 152-158. Nitella flexilis [(152, 154-155, 157) after KRAUSE (1997); (153, 156, 158) after DAMBSKA (1964)]: (152-153) macroscopic habitus; (154-156) branchlet node with oogonia and antheridia; (157) oospore; (158) ends of branching. Scale bars $0.5 \mathrm{~cm}$ (Figs 155-158) and $1 \mathrm{~cm}$ (Figs 152-154).

Norway, Sweden, Finland, Hungary, Germany, Denmark, Poland, Spain, France and Portugal (KRAUSE 1997). There have been local sightings (12 sites) also in the Czech Republic (Fig. 142).

Nitella flexilis (L.) AG., Syst. Alg., p. 124, 1824; Figs 151-158.

Synonyms: Nitella flexilis f. antheridiis Leonh. in Vilhelm, Mém. Soc. Roy. Sci. Boheme, p. 77, 1914, incl.; Nitella flexilis f. brevifolia A. BR. in VilHeLm, Mém. Soc. Roy. Sci. Boheme, p. 77, 1914, incl.; Nitella flexilis f. laxa Vilhelm, Mém. Soc. Roy. Sci. Boheme, p. 77, 1914, incl.; Nitella flexilis f. subcapitata A. BR. in Vilhelm, Mém. Soc. Roy. Sci. Boheme, p. 77, 1914, incl. - WOOD \& IMAHORI, 1965: p. 372; Krause, 1997: p. 146.

The appearance varies widely (Figs 152-153), polymorphic species. Stem: up to 4-20 (100) $\mathrm{cm}$ tall, slender, pale, bright to brownish green (black), occasionally incrustated. Internodes: slender to broad, 1-4 times the length of the branchlets, variable. Branchlets: 4-8 (10) fertile and 4-8 (10) sterile in a whorl, forming dense clusters (Fig. 153), fertile 1 (2)-furcated, sterile usually similar to fertile. Dactyls: 1-celled, acute, conical, rarely reduced (Fig. 158). Plants monoecious. Gametangia: conjoined, solitary or aggregate at all branchlet nodes, without mucus.
Oogonia: $1-3$ at a node, $600-900 \times 550-750 \mu \mathrm{m}$ (Figs 154-155), mature oospores red or pale to dark brown and black colour with marked stripes, granulated and papillated or smooth (Fig. 157). Antheridia: solitary and large, $500-800 \mu \mathrm{m}$ in diameter (Figs 154, 156).

Ecology: Common in frehwaters, but not in calcareous type of biotopes. Occasionally recorded from brackish waters (N. flexillis f. laxa VILHELM).

Distribution: Worldwide, records from North and South America, Africa, Asia and Europe, not yet recorded from Australia (DAmBSKA 1964, Wood \& IMAHORY 1965). In Europe it has been reported as common from England, Scotland, Ireland, Hungary, Germany, Austria, Poland and France (KRause 1997). In the Czech Republic it is common species, in more than 100 localities (Fig. 151).

Nitella gracilis (Sм.) Ag., Syst. Alg., p. 125, 1824; Figs 159-168.

Synonyms: Nitella gracilis f. brevifolia A. BR. in Vilhelm, Mém. Soc. Roy. Sci. Boheme, p. 82, 1914, incl.; Nitella gracilis f. condensata RaBH. in Vilhelm, Mém. Soc. Roy. Sci. Boheme, p. 82, 1914, incl.; Nitella gracilis f. conglobata A. Br. in Vilhelm, Mém. Soc. Roy. Sci. Boheme, p. 82, 1914, incl.; Nitella gracilis f. elongata A. Br. in Vithelm, Mém. Soc. Roy. Sci. 
Boheme, p. 81, 1914, incl.; Nitella gracilis f. normalis Leonh. in Vilhelm, Mém. Soc. Roy. Sci. Boheme, p. 82, 1914, incl.; Nitella gracilis f. polyglochin SIEGMUND. in Vilhelm, Mém. Soc. Roy. Sci. Boheme, p. 82, 1914, incl.; Nitella gracilis f. robustior A. BR. in VILHELM, Mém. Soc. Roy. Sci. Boheme, p. 82, 1914, incl. - WooD \& IMAHORI, 1965: p. 597; Krause, 1997: p. 87.

The appearance varies widely (Figs 160-162). Stem: up to 4-20 (30) cm tall, slender, delicate, green, usually without incrustation. Internodes: 1-4 (15) times the length of the branchlets. Branchlets: 5-8 (9) fertile in a whorl, 2-3 divided, forming dense clusters (Figs 164-166), fertile 1 or 3 -furcated, sterile similar to fertile, but reduced. Dactyls: 2 or 3-celled, end cells as broad as the penultimate cell, conical, acute forming a spear (not mucro), rarely curved (Fig. 163). Plants monoecious. Gametangia: conjoined at all branchlet nodes without first, with or without mucus. Oogonia: solitary, rarely $2-3$ at a node, 290-490 x 225-350 $\mu \mathrm{m}$ (Fig. 167), mature oospores yellowish or pale to dark brown and black colour with marked stripes and granulated (Fig. 168). Antheridia: solitary and small, 200$300 \mu \mathrm{m}$ in diameter (Fig. 167).

Ecology: Freshwaters, common in ponds, ditches and pits.

Distribution: Worldwide, records from North and South America, Australia, Africa, Asia and
Europe (DĄMBSKA 1964, WoOD \& IMAHORY 1965). In Europe it has been reported to be common in Finland, Norway, Hungary, Germany, Denmark, Poland, Spain, France, Portugal and Italy (KRAUSE 1997). 18 localities have been found in the Czech Republic (Fig. 159).

Nitella mucronata (A. BR.) MIQ. in VAN HALL, Fl. Belg. Sept., 2: p. 428, 1840; Figs 169-176. Synonyms: Wood \& IMAHORI, 1965: p. 351.

The appearance varies widely (Figs 170-173). Stem: up to $20-30 \mathrm{~cm}$ tall, rather slender, green to brown, without incrustation. Internodes: firm, 1-2 times the length of the branchlets. Branchlets: 5-6 in a whorl, 2-3 divided, sterile branchlets

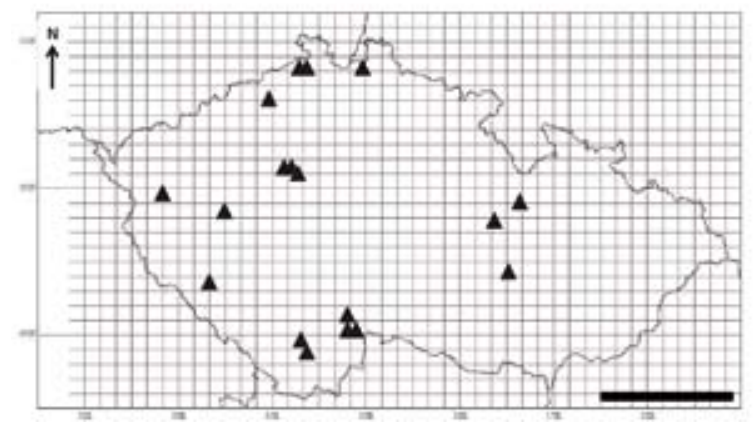

Fig. 159. Distribution of Nitella gracilis in the Czech Republic (scale bar $100 \mathrm{~km}$; for localities see attachment).

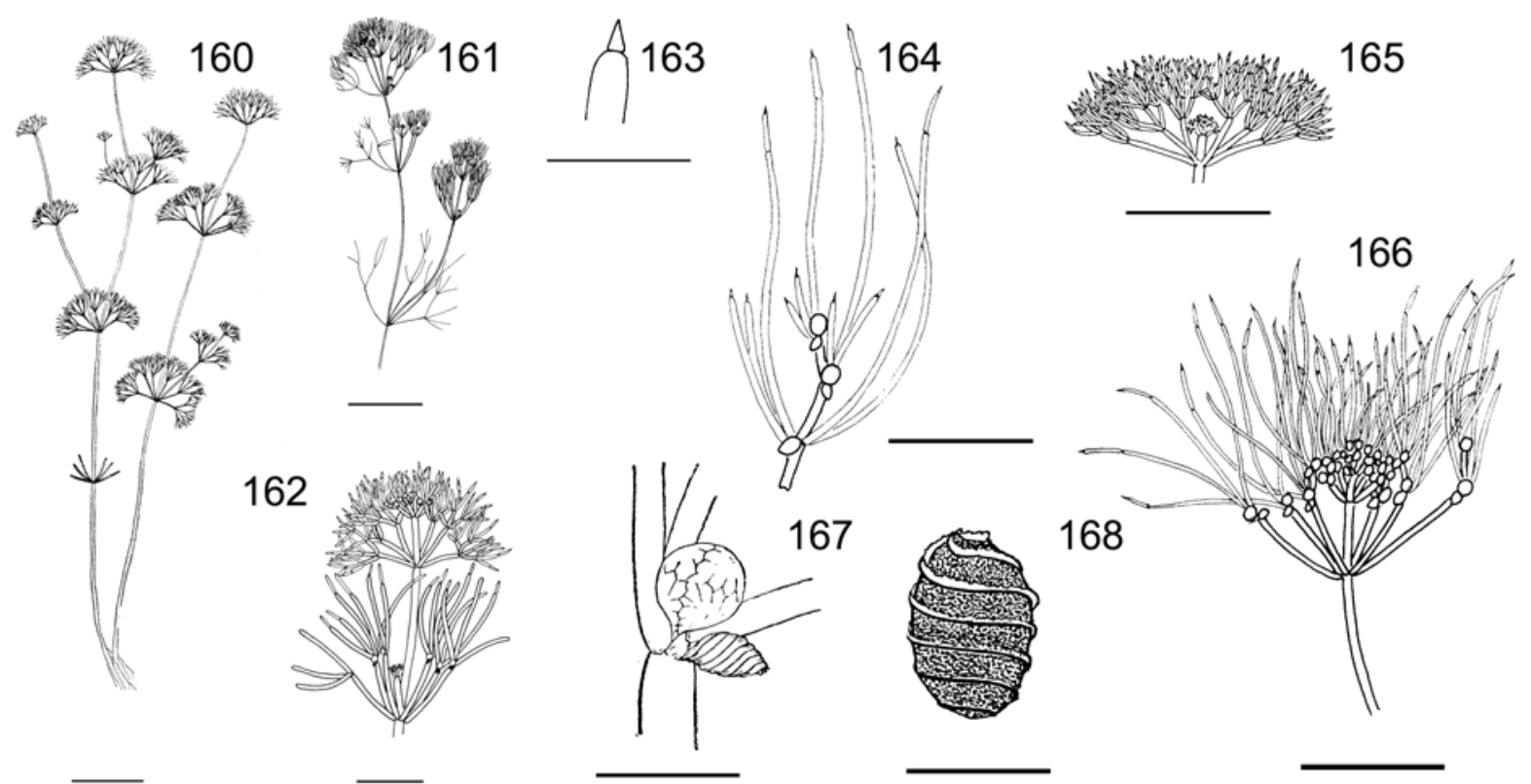

Figs 160-168. Nitella gracilis [(160) after DAMBSKA (1964); (161-168) after KRAUSE (1997)]: (160-162) macroscopic habitus; (163) ends of branching; (164-166) branching; (167) branchlet node with oogonia and antheridia; (168) oospore. Scale bars $0.5 \mathrm{~cm}$ (Figs 163-168) and $1 \mathrm{~cm}$ (Figs 160-162). 
2-furcated, fertile 3-furcated, compacted into heads (Fig. 173). Dactyls: 2-3-celled, very short and tapered, forming a mucro, end cells narrower than penultimate cell (Fig. 174). Plants monoecious. Gametangia: solitary or conjoined at all branchlet nodes except for the first, without mucus. Oogonia: solitary or geminate, 430-625 x 420-450 $\mu \mathrm{m}$ (Figs 174-175), mature oospores brown to black colour with marked stripes and reticulate membrane (Fig. 176). Antheridia: solitary and small, $240-300 \mu \mathrm{m}$ in diameter (Fig. 174).

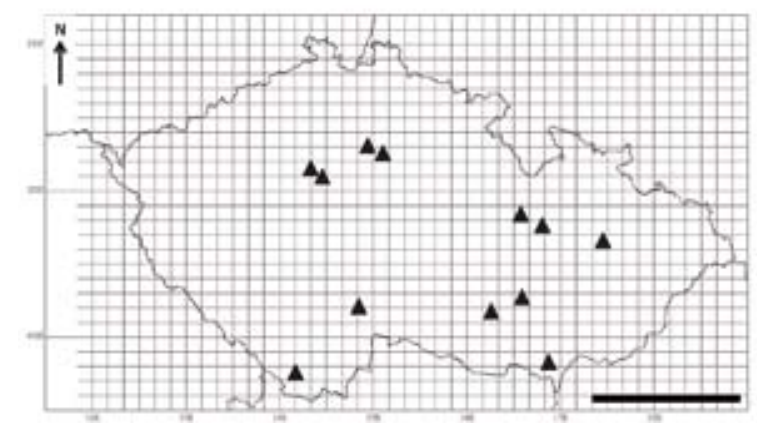

Fig. 169. Distribution of Nitella mucronata in the Czech Republic (scale bar $100 \mathrm{~km}$; for localities see attachment).
Ecology: Not well known.

Distribution: Worldwide, reports from Central and South America, Africa, Asia, Europe (DĄMBSKa 1964). In Europe it is common from Finland, Hungary, Spain, Poland and France, locally in Ireland, Norway and Turkey (KRAUSE 1997). It has been reported to be locally sighted (12 sites) in the Czech Republic (Fig. 169).

Nitella opaca (BRUZ.) AG., Fl., p. 124, 1824; Figs 177-186.

Synonyms: Nitella opaca f. conglobata Mig., Rabenh. Krypt. Fl., p. 131, 1897, incl.; Nitella opaca f. conglomerata A. BR. in Mig., Rabenh. Krypt. Fl., p. 131, 1897, incl.; Nitella opaca f. flexiloides Vilhelm, Hedwigia Bd.LXIV., p. 150, 1922, incl.; Nitella opaca f. heteromorpha Mig., Rabenh. Krypt. Fl., p. 131, 1897, incl.; Nitella opaca f. laxa A. Br. in Mig., Rabenh. Krypt. Fl., p. 128, 1897, incl.; Nitella opaca f. longifolia VILHeLm, Hedwigia Bd.LXIV., p. 150, 1922, incl.; Nitella opaca f. subcapitata MIG., Rabenh. Krypt. Fl., p. 130, 1897, incl.; Nitella opaca f. pseudoflexilis Vilhelm, Mém. Soc. Roy. Sci. Boheme, p. 71, 1914, incl.; Nitella opaca f. simplici VILHELM, Hedwigia Bd. LXIV., p. 150, 1922, incl. - WOOD \& IMAHORI, 1965: p. 380; Krause, 1997: p. 148.

Plants are similar to $N$. flexilis. In sterile condition, it is not possible distinguish $N$. opaca from $N$.
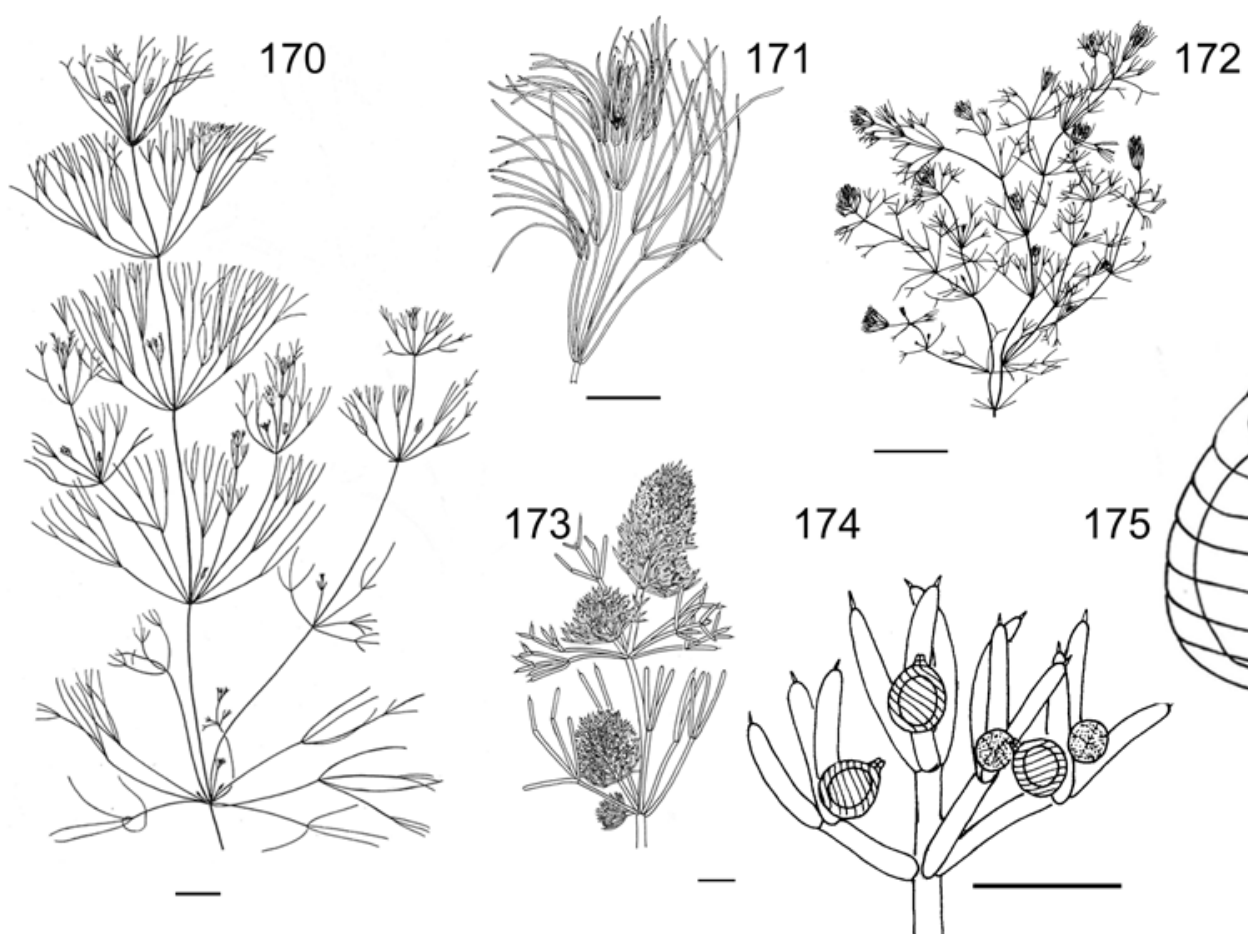

174
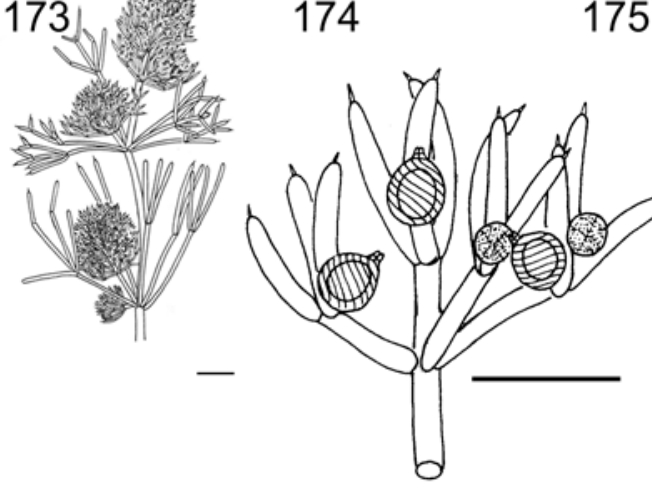

Figs 170-176. Nitella mucronata [(170, 175) after DAMBSKA (1964); (171-174, 176) after KRAUSE (1997)]: (170-173) macroscopic habitus; (174-175) oogonia; (176) oospore. Scale bars $0.2 \mathrm{~cm}$ (Fig. 175), $0.5 \mathrm{~cm}$ (Figs 174, 176) and $1 \mathrm{~cm}$ (Figs 170-173). 
flexilis. Stem: up to 10-50 (90) cm tall, robust, dark green to brown, incrustated (Figs 178-181). Internodes: elongated, variable. Branchlets: 6 in a whorl, not forming dense clusters, but isolated, fertile 1-furcated, sterile similar to fertile (Fig. 181). Dactyls: 1-celled, acute, conical (Fig. 182). Plants dioecious. Gametangia: solitary or geminate at all branchlet nodes, without mucus. Oogonia: $1-2$ at a node, $450-500 \times 400-460 \mu \mathrm{m}$ (Figs 183-184), mature oospores dark brown and black colour with marked stripes or smooth (Fig. 186). Antheridia: solitary, 600-700 $\mu \mathrm{m}$ in diameter (Fig 185).

Ecology: Common in shallow water reservoirs and rivers.

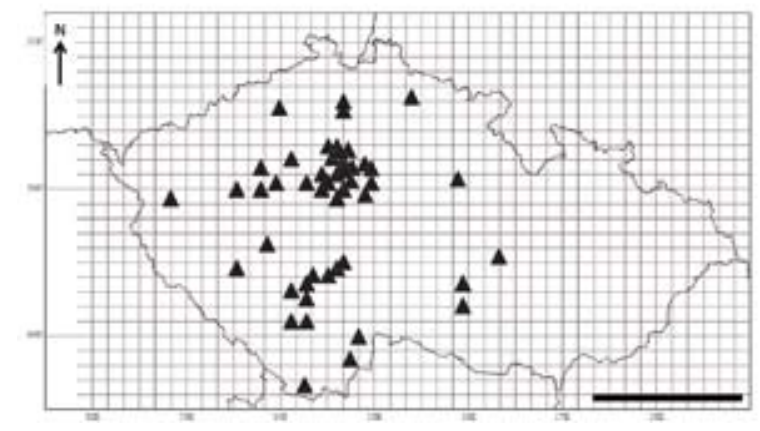

Fig. 177. Distribution of Nitella opaca in the Czech Republic (scale bar $100 \mathrm{~km}$; for localities see attachment).
Distribution: Widely distributed in North America and Europe (DĄmBSKA 1964, Wood \& IMAHORY 1965). In Europe it has been recorded from Germany, Austria, Slovakia, Poland, Sweden, Switzerland, Norway, Portugal and Balkan (KRAUSE 1997, BlAŽENČIĆ et. al. 2006). It has been reported from more than 20 sites in the Czech Republic (Fig. 177).

Nitella syncarpa (Thuill.) Chev., Fl. Gen., 2: p. 125, 1827; Figs 187-194.

Synonyms: Nitella capitata (NeEs) Agardh, Syst. Alg., p. 125, 1824; Nitella capitata f. capituligera A. BR. ex Mig., Rabenh. Krypt. Fl., p. 117, 1897, incl.; Nitella capitata f. longifolia A. BR. ex Mig., Rabenh. Krypt. Fl., p. 118, 1897, incl.; Nitella capitata f. elongata Leonh. in Vilhelm, Mém. Soc. Roy. Sci. Boheme, p. 69, 1914, incl.; Nitella syncarpa f. laxa VilHelm, Mém. Soc. Roy. Sci. Boheme, p. 66, 1914, incl. - Wood \& IMAHORI, 1965: p. 413; KRAUSE, 1997: p. 144.

The appearance varies widely (Figs 188-189). Stem: up to 10-25 (50) cm tall, slender, grey to green, occasionally incrustated, male plant with thicker mucus. Internodes: 1-3 times the length of the branchlets, varying widely. Branchlets: 6 fertile in a whorl, fertile 1-furcated, sterile similar to fertile (Fig. 191). Dactyls: 1-celled, conical or slightly reduced (Fig. 190). Plants diecious.
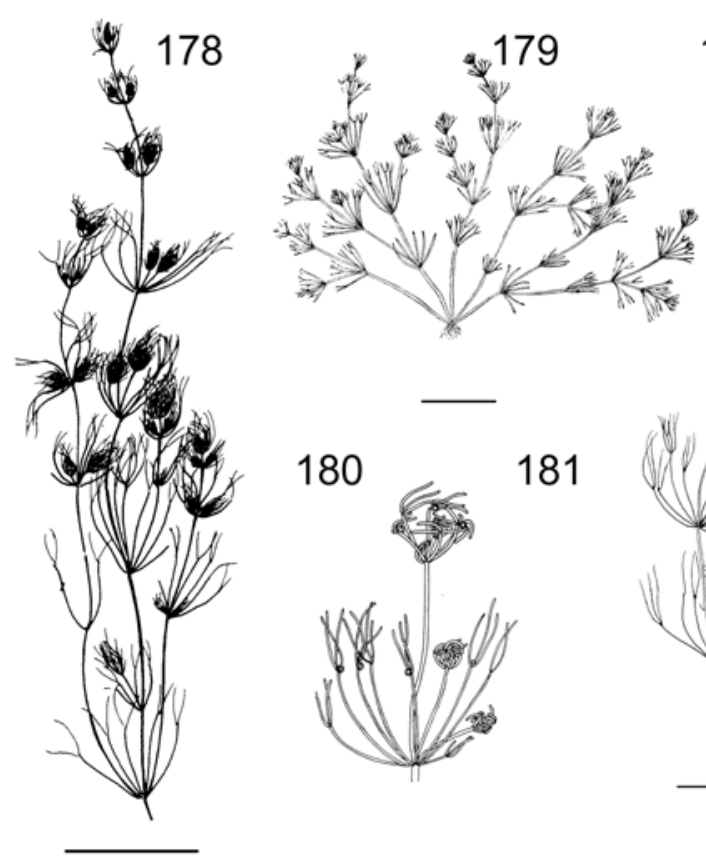

182

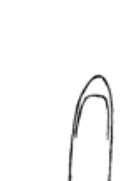

183
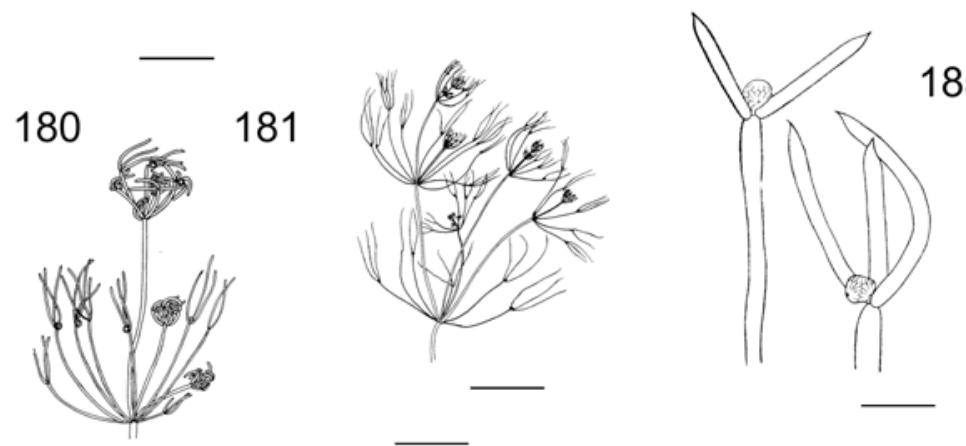

185

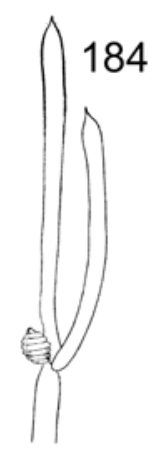

181

Figs 178-186. Nitella opaca [(178, 180-183, 186) after KRAUSE (1997); (179, 184-185) after DÁmBSKA (1964)]: (178-181) macroscopic habitus; (182) ends of branching; (183-185) branchlet node with oogonia and antheridia; (186) oospore. Scale bars $0.2 \mathrm{~cm}$ (Figs 184-185), $0.5 \mathrm{~cm}$ (Figs 182, 186) and $1 \mathrm{~cm}$ (Figs 178-181, 183). 
Gametangia: solitary, geminate or agregate (in small heads) at fertile branchlet nodes, with mucus (Fig. 191). Oogonia: aggregate, (460) 500-690 x 420-525 $\mu \mathrm{m}$ (Fig. 192), mature oospores pale brown to dark brown or black colour with marked stripes or smooth (Fig. 194). Antheridia: solitary and small, up to $700 \mu \mathrm{m}$ in diameter (Figs 191, 193). The fertile plants are found in autumn.

Ecology: Shallow ponds.

Distribution: Widely recorded from Europe (Norway, Finland, Germany, Denmark, Poland, France, Spain and Italy) (DAmBBSKa 1964, Wood \& Imahory 1965, Krause 1997). There have been local sightings (16 sites) also in the Czech Republic (Fig. 187).

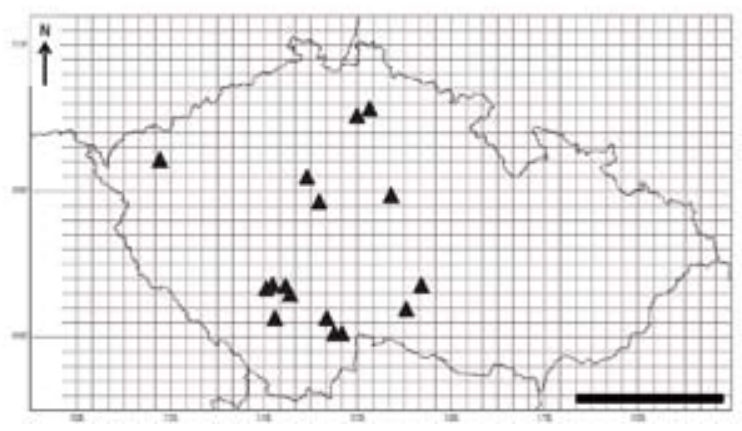

Fig. 187. Distribution of Nitella syncarpa in the Czech Republic (scale bar $100 \mathrm{~km}$; for localities see attachment).
Nitella tenuissima (Desv.) Kütz., Phyc. Gen., p. 319, 1843; Figs 195-204.

Synonyms: Wood \& Imahori, 1965: p. 544; Krause, 1997: p. 150.

The appearance varies widely (Figs 196-198). Stem: up to 3-12 (20) cm tall, slender, pale to dark green, moderately incrustated. Internodes: $2-5$ times the length of the branchlets. Branchlets: 5-8 fertile in a whorl, fertile 2 or 4-furcated, sterile similar to fertile, occasionally longer (Figs. 198, 200). Dactyls: 2-celled, end cells acuminate, acute, conical, rarely blunt, usually without mucro formations (Fig. 199). Plants monoecious. Gametangia: rarely solitary, conjoined or sejoined at $2^{\text {th }}$ and $3^{\text {th }}$ branchlet nodes, without mucus. Oogonia: solitary, 270-550 x 225-410 $\mu \mathrm{m}$ (Figs 200, 202-203), mature oospores yellowish or pale to dark brown and black colour with marked stripes and granulated (Fig. 204). Antheridia: solitary and small, 130-200 $\mu \mathrm{m}$ in diameter (Fig. 202).

Ecology: Calcareous pools and ponds.

Distribution: North America, Asia and Europe (DĄmBSKa 1964, WoOd \& IMAHORY 1965). In Europe it has been reported as common from Finland, Norway, Sweden, Denmark, German, Poland, Spain, Portugal, Italy and Balkan (KRAUSE 1997, URBANiAK et al. 2008). There have been only 3 local sightings in the Czech Republic (Fig. 195).

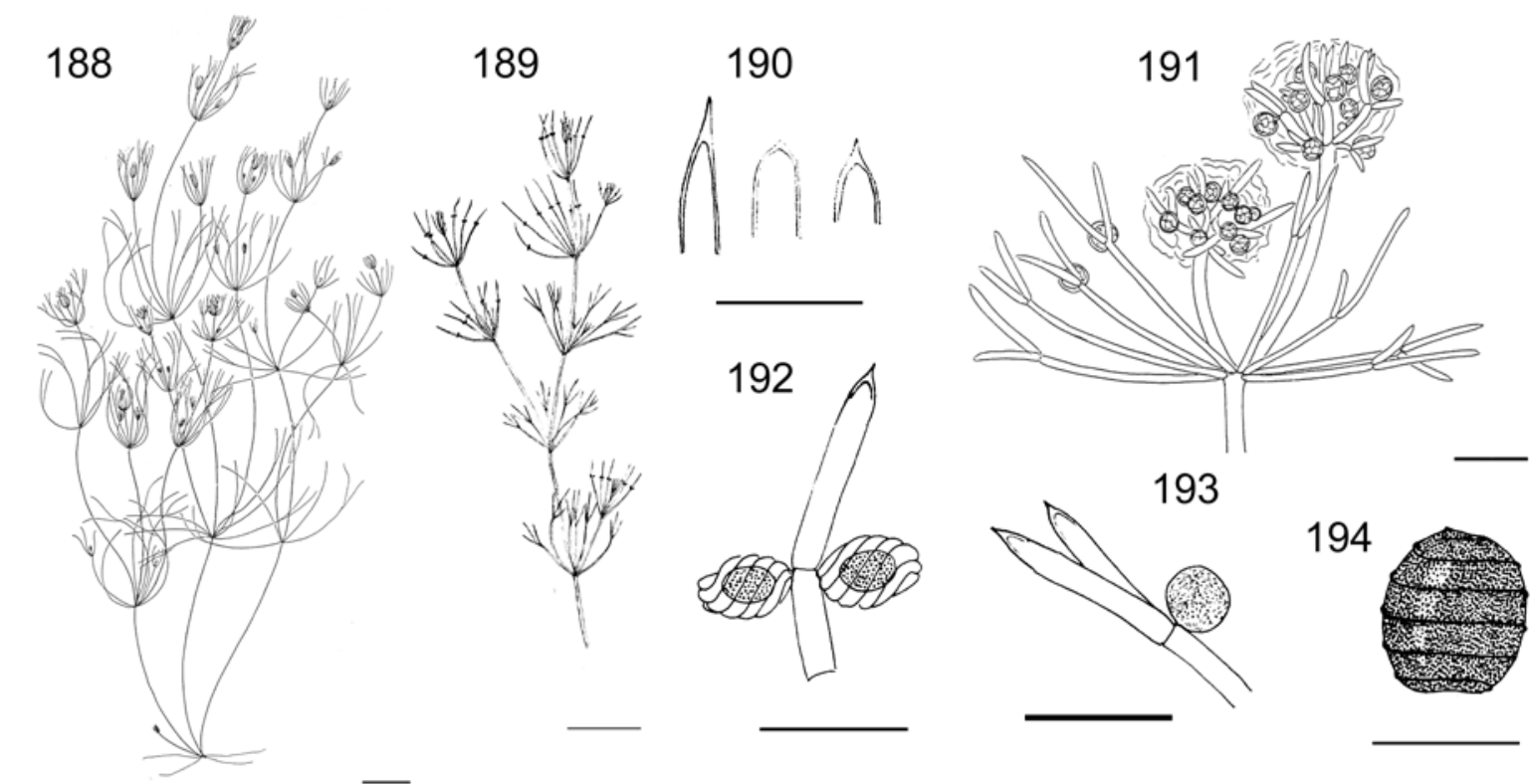

Figs 188-194. Nitella syncarpa [(188) after Wood \& IMAHORY (1965); (189-190) after DAMBSKA (1964); (191-194) after KRAUSE (1997)]: (188-189) macroscopic habitus; (190) ends of branching; (191-193) branchlet node with oogonia and antheridia with mucus; (194) oospore. Scale bars $0.2 \mathrm{~cm}$ (Figs 192-193), $0.5 \mathrm{~cm}$ (Figs 190, 194) and $1 \mathrm{~cm}$ (Figs 188-189, 191). 
Nitellopsis obtusa (DEsv. in LoIs.) J. Gr., J. Bot., 57: p. 127, 1919; Figs 205-216.

Synonyms: WoOd \& IMAhori, 1965: p. 351; Krause, 1997: p. 87.

Stem: up to $20 \mathrm{~cm}$ tall $(20-200 \mathrm{~cm})$, robust, green, moderately or heavily incrustated (Figs 206-207). Internodes: broad, lenght similar to the branchlets (Fig. 207). Nodes: robust (Figs 208-209). Branchlets: very long, 5-8 in a whorl, of 2-3 segments, end cells elongate, acuminate or mucronate (Fig. 207). Cortex, Spine cells, Stipulodes and Bracteoles absent. Plants dioecious. Gametangia: heterothallic plants.

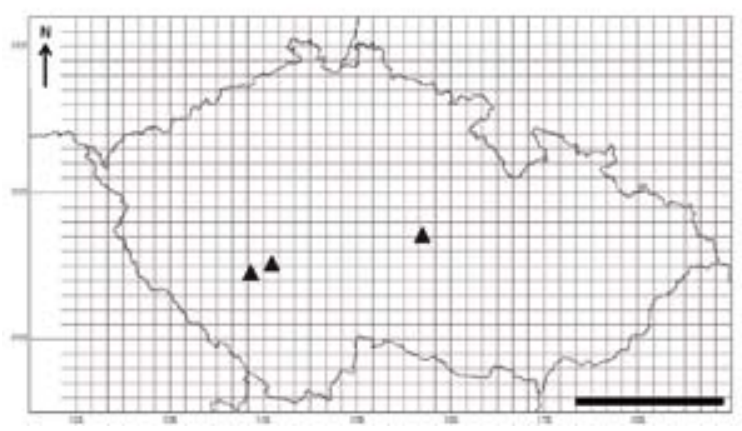

Fig. 195. Distribution of Nitella tenuissima in the Czech Republic (scale bar $100 \mathrm{~km}$; for localities see attachment).
Oogonia solitary or geminate at 1-2 lowest branchlets nodes, 1035-1125 x 825-990 $\mu \mathrm{m}$ (Figs 211-212), mature oospores golden brown colour with marked stripes and granulated (Fig. 214). Antheridia: solitary or geminate, $1000 \mu \mathrm{m}$ in diameter (Figs 210, 213). Bulbils: white, large, stellate (Figs 215-216).

Ecology: Large ponds.

Distribution: Recorded in Asia and Europe (DĄMBSKa 1964, WoOd \& IMAHory 1965). In Europe it has been reported from France, Germany, Poland, Denmark, Spain and Italy (KRAUSE 1997). In the Czech Republic it has been recorded from two localities (Fig. 205).

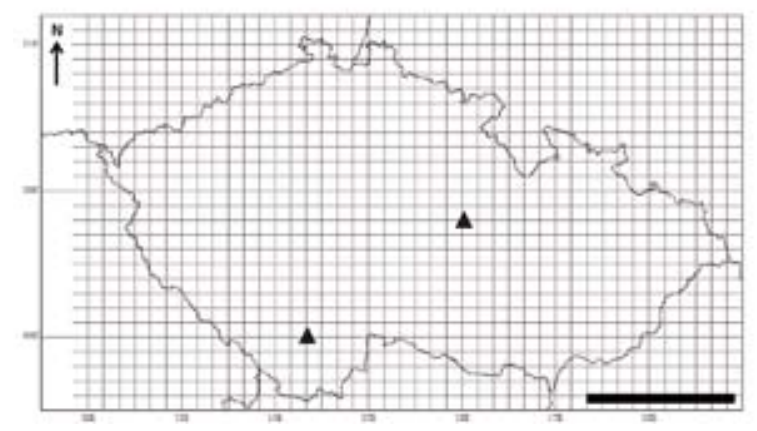

Fig. 205. Distribution of Nitellopsis obtusa in the Czech Republic (scale bar $100 \mathrm{~km}$; for localities see attachment).

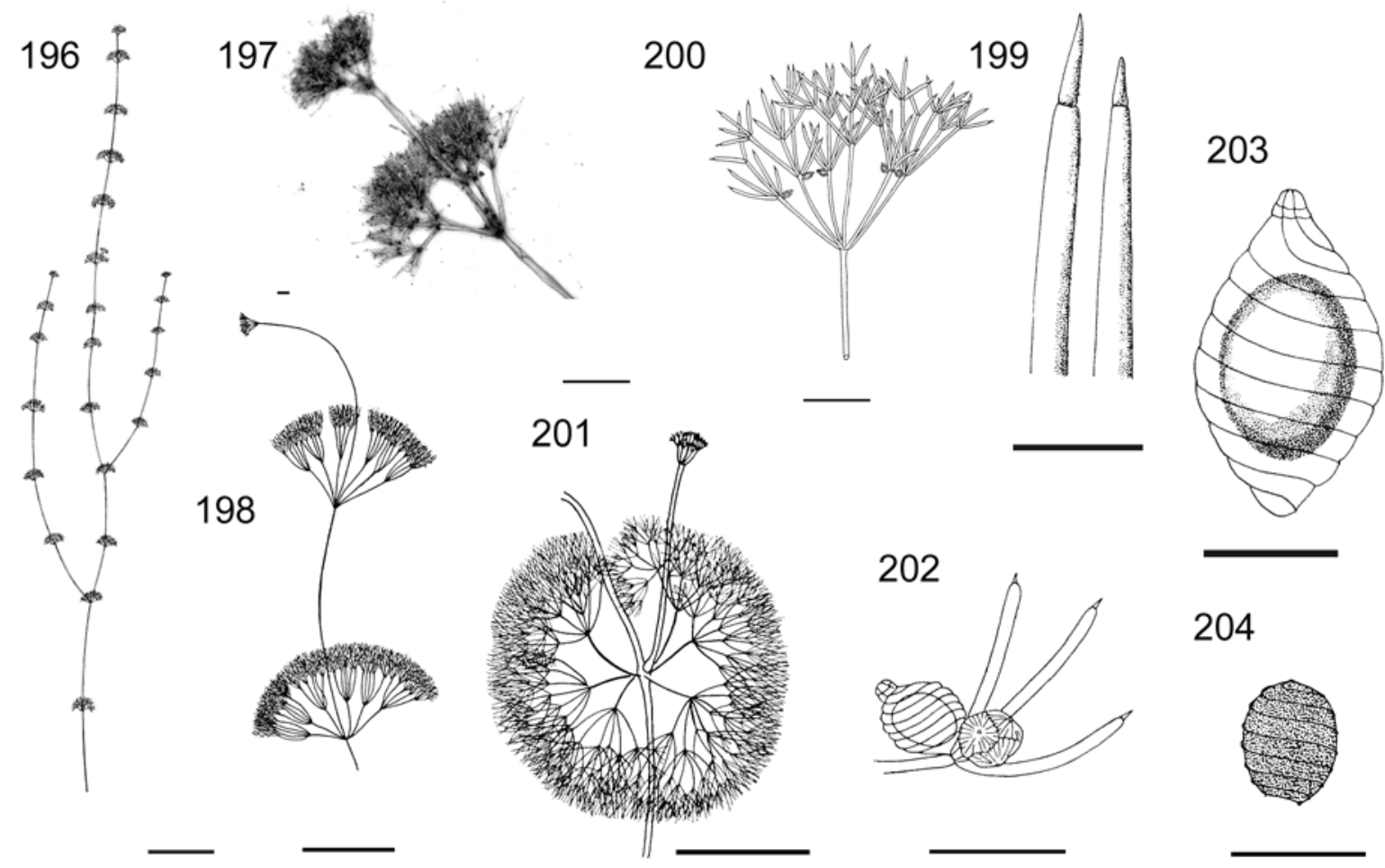

Figs 196-204. Nitella tenuissima [196, 198-202, 204 after KRAUSE (1997); (197) orig. CAISOvÁ; (203) after DĄMBSKA (1964)]: (196-198) macroscopic habitus; (199) ends of branching; (200-202) branchlet node with oogonia and antheridia with mucus; (203) oogonium; (204) oospore. Scale bars $0.2 \mathrm{~cm}$ (Figs 202-203), $0.5 \mathrm{~cm}$ (Figs 199, 204) and $1 \mathrm{~cm}$ (Figs 196-198, 200201). 


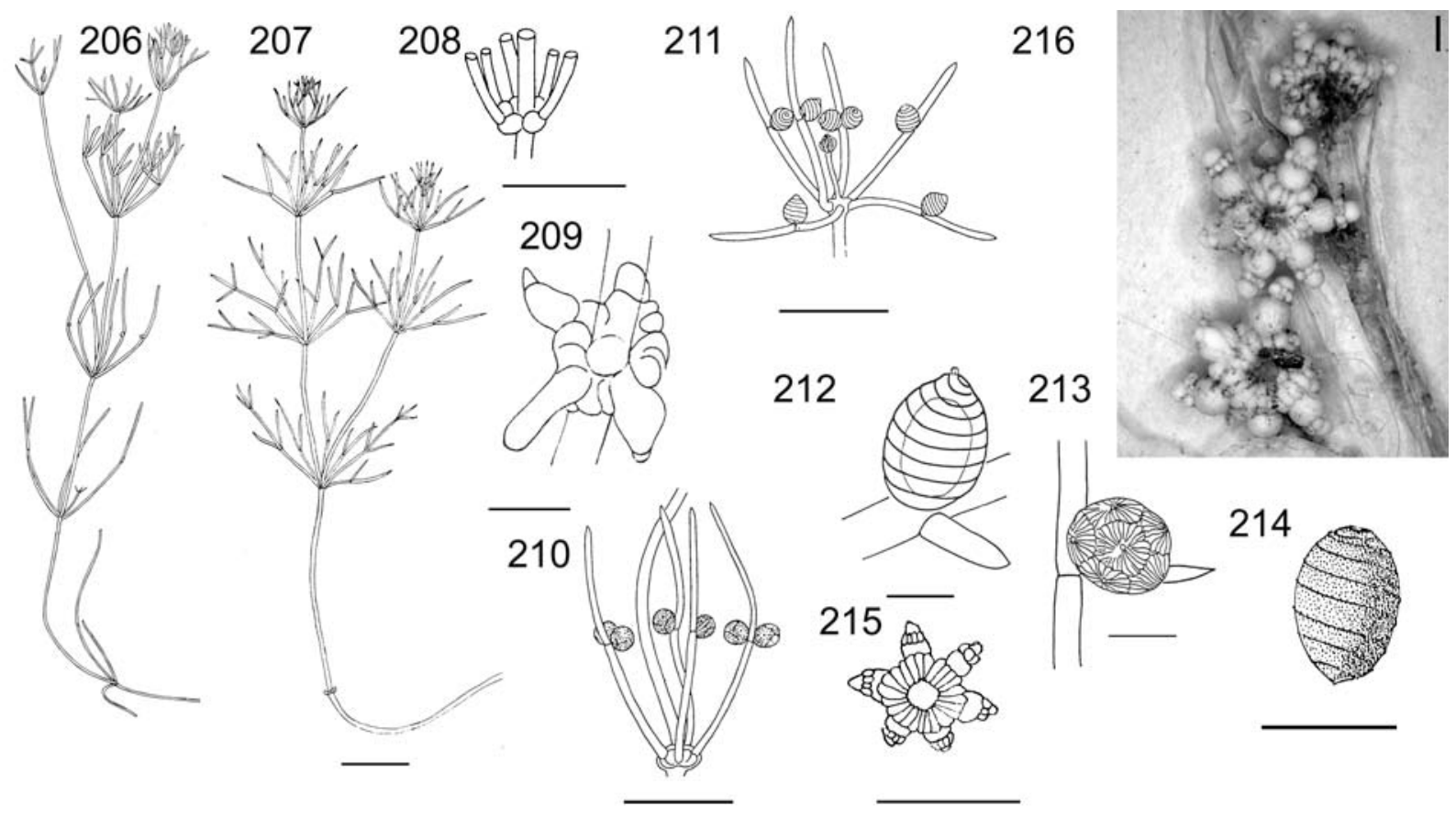

Figs 206-216. Nitellopsis obtusa [(206, 208, 210-211, 214) after Krause (1997); (207, 215) after DamBSKa (1964); (209, 212-213) after Wood \& IMAHoRY (1965); (216) orig. CAISOVÁ]: (206-207) macroscopic habitus; (208-209) nodes; (210-213) branchlet node with oogonia and antheridia; (214) oospore; (215-216) bubils. Scale bars $0.2 \mathrm{~cm}$ (Figs 210, 215-216), 0.5 cm (Figs 208-209, 212-214) and $1 \mathrm{~cm}$ (Figs 206-207, 211).

Tolypella glomerata (DEsv. in LoIs.) R. D. W., Taxon, 11: p. 23, 1962; Figs 217-223.

Synonyms: WoOd \& IMAHORI, 1965: p. 733; KraUSE, 1997: p. 165.

Stem: up to 5-25 cm tall, slender, grey or green, heavily incrusted (Figs 218-220). Internodes: 1-2 times the length of the branchlets (Fig. 219). Branchlets: 5-8 (10) fertile and 6-12 (13) sterile in a whorl, forming dense heads (Figs 218-220), end segment (3-5 cells) obtuse. Terminal cells of branchlets: rudimentary, conical (Fig. 221). Plants monoecious. Gametangia: on separate plants or conjoined at fertile branchlet nodes or aggregate at base of branchlets. Oogonia 1-3 at a node, $425-700 \times 310-545 \mu \mathrm{m}$ (Fig. 222), mature oospores golden brown to dark brown or blackish colour with marked stripes and granulated or smooth (Fig. 223). Antheridia: solitary and small, $300-400 \mu \mathrm{m}$ in diameter (Fig. 222).

Ecology: Freshwaters, especially shallow ponds, pools and fish keepers.

Distribution: Worldwide, records from North America, Australia, Africa, Asia and Europe (DĄmBska 1964, WoOd \& IMAHORY 1965). In Europe it has been reported from Sweden, Norway, Ireland, France, Spain, Germany, Denmark, Poland and Balkan (KRAUSE 1997). There have been local

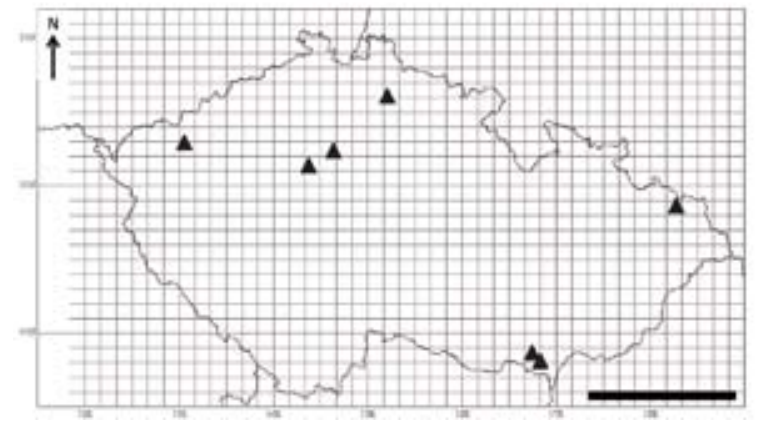

Fig. 217. Distribution of Tolypella glomerata in the Czech Republic (scale bar $100 \mathrm{~km}$; for localities see attachment).

sightings (7 sites) in the Czech Republic (Fig. 217).

Tolypella intricata (Trent. ex Roth.) Leonh., Lotos, 13: p. 57, 1863; Figs 224-230.

Synonyms: Wood \& Imahori, 1965: p. 735; Krause, 1997: p. 171.

The appearance varies widely (Figs 225-226). Stem: up to $8-50 \mathrm{~cm}$ tall, slender, grey to green, moderately to heavily encrustated, formed large and dense heads. Internodes: 1-3 times the length of the branchlets (Fig. 225). Branchlets: $4-8$ fertile and 6-20 sterile in a whorl, simple or once divided, forming dense clusters (Figs 226, 228). 

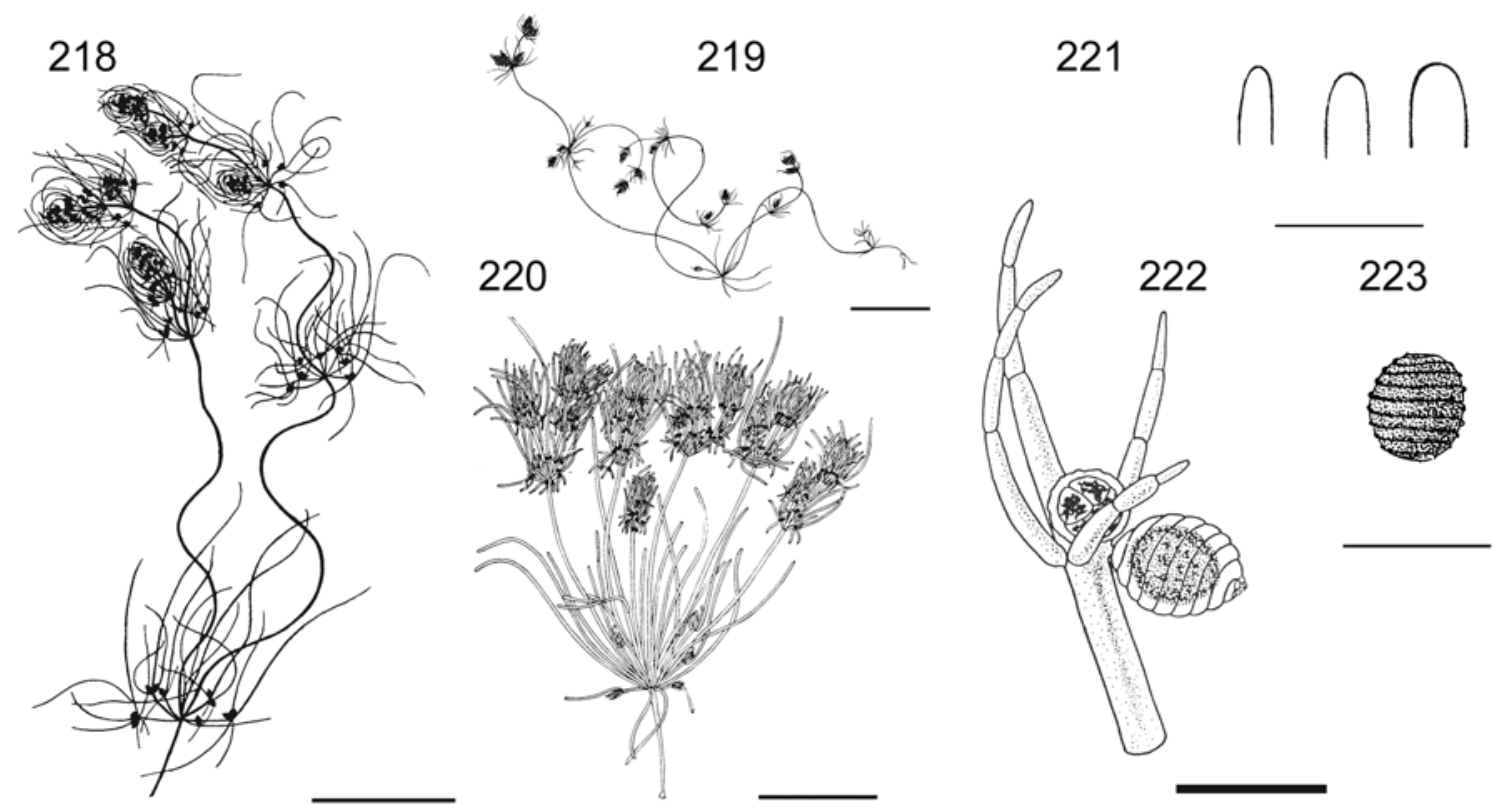

Figs 218-223. Tolypella glomerata [(218-220, 223) after KRAUSE (1997); (221) after DĄmBSKA (1964); (222) after Wood \& IMAHORY (1965)]: (218-220) macroscopic habitus; (221) ends of branching; (222) oogonia and antheridia; (223) oospore. Scale bars $0.2 \mathrm{~cm}$ (Fig. 222), $0.5 \mathrm{~cm}$ (Figs 221, 223) and $1 \mathrm{~cm}$ (Figs 218-220).

Terminal cells of branchlets: conical, rarely forming mucro (Fig. 227). Plants monoecious. Gametangia: conjoined or sejoined at fertile branchlet nodes, without mucus. Oogonia: $1-4$ at a node, 350-560 x 300-450 $\mu \mathrm{m}$ (Figs 228-229), mature oospores yellow, pale to dark brown colour, granulated or smooth (Fig. 230). Antheridia: solitary and small, up to $500 \mu \mathrm{m}$ in diameter (Fig. 228).

Ecology: Freshwaters, especially streams, pools and ponds.

Distribution: Records from North and South America, Afrika, Asia and Europe (DAMBSKA 1964, WoOd \& IMAHORY 1965). In Europe it has been reported from Scandinavia, Ireland, England, Germany, Austria, Denmark, Poland and Balkan (Krause 1997). In the Czech Republic it has been recorded from 5 sites (Fig. 224).

Tolypella prolifera (Zız. ex A. BR.) R. D. W., Phyc. Germ., p. 255, 1845; Figs 231-237.

Synonyms: WoOd \& IMAHORI, 1965: p. 743; Krause, 1997: p. 174.

Stem: up to $20-40 \mathrm{~cm}$ tall, slender, grey to green, moderately encrusted (Fig. 232). Internodes: 1-2 times the length of the branchlets (Fig. 232). Branchlets: 5-7 fertile and 6-20 sterile in a whorl, 3-5 cells, 1-2 divided, forming

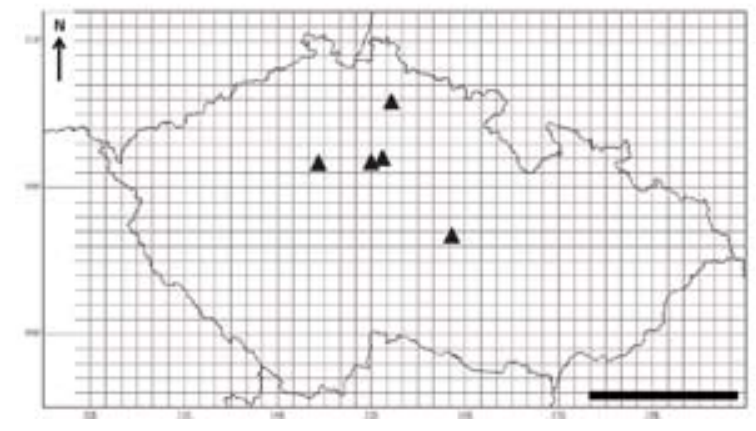

Fig. 224. Distribution of Tolypella intricata in the Czech Republic (scale bar $100 \mathrm{~km}$; for localities see attachment).

dense clusters (Figs 233-234). Terminal cells of branchlets: forming small mucro (Fig. 235). Plants monoecious. Gametangia: conjoined at the branchlet nodes, without mucus. Oogonia: $1-4$ at a node, $500-560 \times 360-450 \mu \mathrm{m}$ (Fig. 236), mature oospores pale to dark brown colour with marked stripes and granulated or smooth (Fig. 237). Antheridia: central adaxial, small, $300 \mu \mathrm{m}$ in diameter.

Ecology: Shallow freshwaters.

Distribution: Worldwide, known from North and South America, Africa, Asia and Europe (DĄMBSKA 1964, Wood \& Imahory 1965). In Europe it has been reported from Sweden, Norway, Great Britain, France, Spain, Germany, Denmark and Poland (Krause 1997). In the Czech Republic it is 


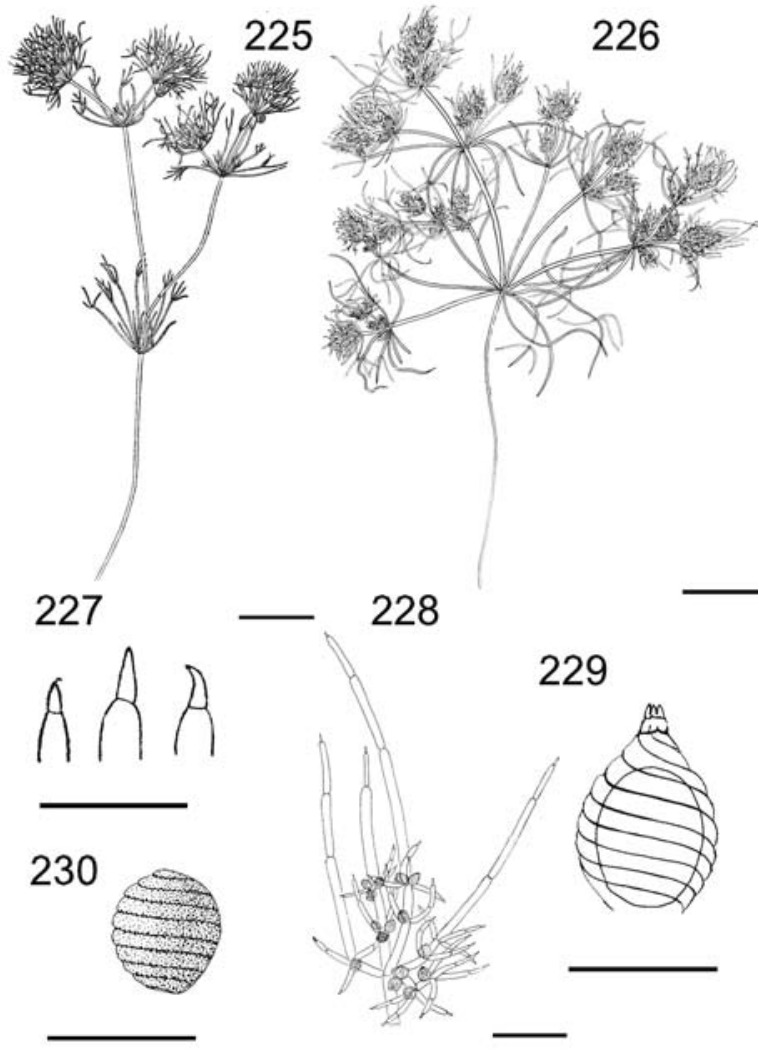

Figs 225-230. Tolypella intricata [(225, 227) after DĄMBSKA (1964); (226, 228-230) after KraUSE (1997)]: (225-226) macroscopic habitus; (227) ends of branching; (228-229) oogonia and antheridia; (230) oospore. Scale bars $0.2 \mathrm{~cm}$ (Fig. 229), $0.5 \mathrm{~cm}$ (Figs 227, 230) and $1 \mathrm{~cm}$ (Figs 225-226, 228).

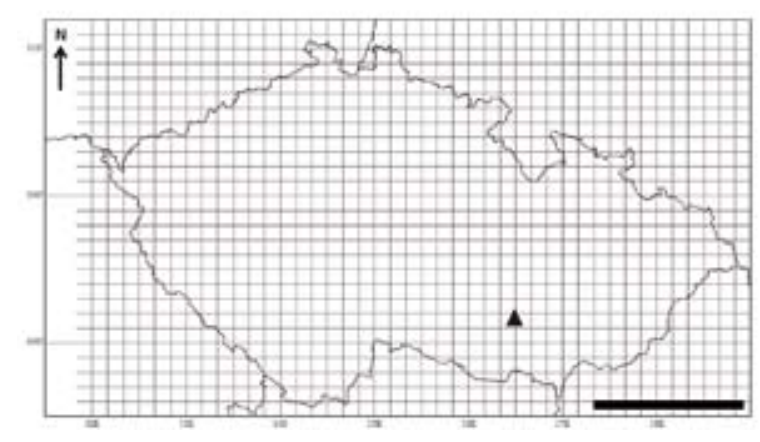

Fig. 231. Distribution of Tolypella prolifera in the Czech Republic (scale bar $100 \mathrm{~km}$; for localities see attachment).

located only in one site (Fig. 231).

\section{Acknowledgement:}

We thank Ing. Luděk Čech, RNDr. Tomáš Hauer Ph.D., RNDr. Štepán Husák CSc., Mgr. Jan and Jiř́i Košnar, RNDr. Petr Koutecký Ph.D., Bc. Markéta Kremlová, RNDr. Jaroslav Rydlo, RNDr. Olga Skácelová Ph.D., RNDr. Karel Sutorý, RNDr. Kateřina Šumberová and RNDr. Alena Vydrová for providing the original data and

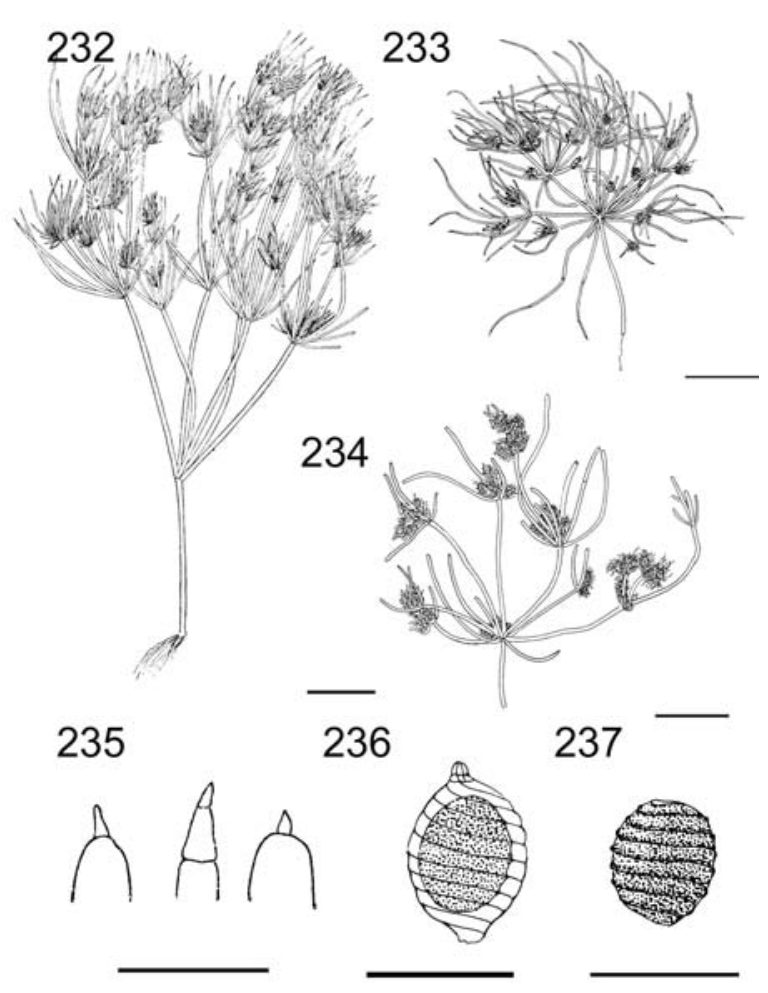

Figs 232-237. Tolypella prolifera $[(232,235)$ after DĄMBSKA (1964); (233-234, 236-237) after KRAUSE (1997)]: (232) macroscopic habitus; (233-234) branching; (235) ends of branching; (236) oogonium; (237) oospore. Scale bars $0.2 \mathrm{~cm}$ (Fig. 236), $0.5 \mathrm{~cm}$ (Figs 235, 237) and $1 \mathrm{~cm}$ (Figs 232-234).

herbarium material. We are special grateful to RNDr. Štepán Husák CSc. for introduction to the problematic of Charophytes. In adittion our special thanks belong to Dąmbska herbarium, National Muzeum in Prague, The Moravian Museum and Museum of Central Bohemia in Roztoky near Prague. We appreciate the help of RNDr. Petr Hašler Ph.D., prof. Jiří Komárek, Mgr. Kristýna Mohlová, doc. Aloisie Poulíčková, Dana Švehlová, RNDr. Eliška Zapomělová Ph.D. for technical support and useful critical comments on the manuscript. This work was supported by project of the Grant Agency CR no 206/09/0697.

\section{References}

Abrol, D. \& Bhatnagar, S.K. (2006): Biodiversity of few Indian charophyte taxa based on molecular characterization and construction of phylogenetic tree. - African Journal of Biotechnology 5: 1511-1518.

Agardh, C.A. (1824): Systema algarum. - 312 pp., Berling, Lund, Sweden.

Baunin, C. (1620): Podromus Theatri Botanici. Francofurtii ad Moenum, $160 \mathrm{pp}$.

Blaženčić, J., Stevanović, B., BlažEnčić, Ž. \& 


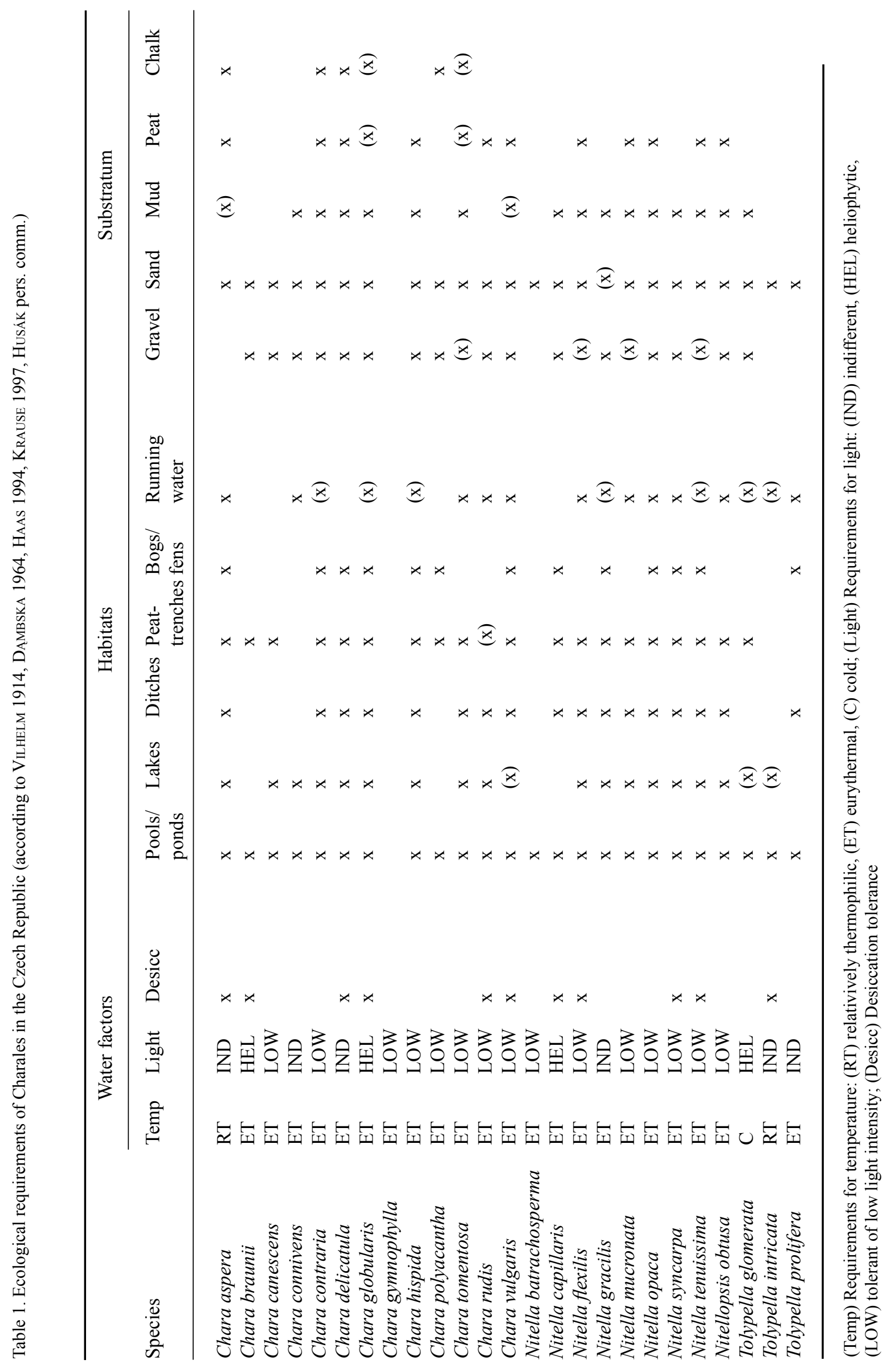


Stevanović, V. (2006): Red data list of Charophytes in the Balkans. - Biodiversity and Conservation 15: 3445-3457.

Blindow, I. (1992): Decline of charophytes during eutrophication; a comparison to angiosperms. Freshwater Biology 28: 9-14.

Blindow, I. \& LANGANGEN, A. (1995): Lamprothamnium papulosum (WALLr.) J. Groves, a threatend charophyte in Scandinavia. - Cryptogamie, Algologie 16: 47-55.

Bonnis, A. \& Grillas, P. (2002): Deposition, germination and spatio-temporal patterns of charophyte propagule banks (a review). Aquatic Botany 72: 235-248.

Boszke, P. \& BociąG, K. (2008): Morphological variation of oospores in the population of Chara rudis A. Braun in a mesotrophic lake. - Polish Journal of Ecology 56: 139-147.

Braun, A. (1849): Charae australes antarcticae, or characters and observations on the Characeae of Australia and the southern circumpolar regions. - Hooker's Journal of Botany \& Kew Garden Miscellany 1: 193-203.

Braun, A. (1876): Characeen. Kryptogamen Flora von Schleisien 1. - pp. 353 - 411, Wrocław.

Caisová, L., Husák, Š. \& KomáRek, J. (2008): Nitella mucronata (Br.) Miquel (Charophyta) in the Czech Republic. - Fottea 8: 105-107.

CASANOva, M.T.(1991):AnSEM study ofdevelopmental variation in oospore wall ornamentation of three Nitella species (Charophyta) in Australia. - Phycologia 30: 237-242.

Casanova, M.T. (1997): Oospore variation in three species of Chara (Charales, Chlorophyta). Phycologia 36: 274-280.

Casanova, M. T. (2007): Typification and circumscription of Nitella sonderi (Characeae, Charophyceae). - Australian Systematic Botany 20: 464-472.

Corillion, R. (1975): Flore des Charophytes du Massif Armorican et des contrees voisinesd'Europe occidental. - 216 pp., Jouve Editeurs, Paris. (in French).

ČelakovskÝ, L. (1876): 1. Mitteilungen zur Flora Böhmens. - 207 pp., Östereichische Botanische Zeitschrift.

ČElakovskÝ, L. (1878): Über die morphologische Bedeutung der sog. Sporensprösschen der Characeen. - 198 pp., Flora.

Čelakovský, L. (1887): Analytická květena českomoravská. II. vyd. (Přídavek Characeae). - pp. 411-414.

DĄmBskA, I. (1964): Charophyta - Ramienice. Flora Słodkowodna Polski t. 13 [Charophyta stoneworts. Freshwater flora of Poland]. - 126 pp., Polska Akademia Nauk, Instytut Botaniki., Warszawa. (in Polish).

Dangeard, P. (1933): Traité d'algologie, introduction a la biologie et a la systématique des algues. Paris, VI. 208-222.

Elliott, G.F. (1984): Modern developments in the classification of some fossil green algae. - In: Irvine, D. E. G. \& John, D. M. (eds): Systematics of the Green Algae. - pp. 297-302, Academic Press London and Orlando.

Feist, M. \& FeIST, R. (1997): Oldest record of a bisexual plant. - Nature 385: 401.

Feist, M. \& Grambast-Fessard, N. (1991): The genus concept in Charophyta: evidence from Palaeozoic to Recent. - In: Riding, R. (ed.): Calcareous algae and stromatolites, vol. 11.-pp. 189-203, Springer Verlag, Berlin, Germany.

Feist, M. \& Grambast-Fessard, N. (1991): The genus concept in Charophyta: evidence from Palaeozoic to Recent. - In: Riding, R. (ed.): Calcareous algae and stromatolites, vol. 11.-pp. 189-203, Springer Verlag, Berlin, Germany.

Feist, M., Liu, J. \& TAFForeau, P. (2005): New insights into paleozoic charophyte morphology and phylogeny. - Americal Journal of Botany 92: 1152-1160.

GĄBKA, M. (2007): Distribution of Chara tenuispina A. Braun 1835 (Characeae) in Poland. Oceanological and Hydrobiological Studies 36: $241-248$.

GąbKa, M., Owsianny, P. M., Burchardt, L. \& SoBCZYŃSKI, T. (2007): Habitat requirements of the Charetum intermediae phytocoenoses in lakes of western Poland. - Biologia 62: 657663.

Graham, L.E. (1993): Origin of land plants. - 287 pp., John Wiley and Sons, New York.

Graham, L.E. \& Wilcox, L.W. (2000): Algae. - pp. 452-493, Prentice Hall - Upper Saddle River.

Ganterer, A. (1847): Die bisher bekannten österreichischen Characeen. - Wien.

Garbary, D.J., Renzaglia, K.S. \& Duckett, J.G. (1993): The phylogeny of land plants: a cladistic analysis based on male gametogenesis. - Plant Systematics and Evolution 188: 237-269.

Grambast, L. (1974): Phylogeny of the Charophyta. Taxon 23: 463-481.

Grant, M.C. \& Proctor, V. (1971): Chara vulgaris and C. contraria: Patterns of reproductive isolation for two cosmopolitan species complexes. Evolution 26: 267-281.

Grant, M.C. (1990): Phylum Chlorophyta. Class Charophyceae. Order Charales. - In Margulis, L., Corliss, J. O., Melkonian M. \& Chapman D.J. (eds): Handbook of Protoctista. - pp. 641648, Jones and Bartlett, Boston, MA.

Groves, J. (1916): On the name Lamprothamnus Braun. - Joural of Botany 54: 125-129.

Grulich, V. \& VydrovÁ, A. (2006): Zpráva Natura 2006. -www.calla.cz/data/boletice/studie.

HAAS, J.N. (1994): First identification key for 
charophyte oospore from central Europe. European Journal of Phycology 29: 227-235.

HANSGIRG, A. (1892): Prodromus der Algenflora von Böhmen. - 112 pp., Archiv für Naturwissenschaftliche Durchforschung von Böhmen, Prag.

HorA, P. (1883): Versuch einer Flora von Pilsen. - 112 pp., Lottos, Prag.

Husák, Š. (1985): Parožnatky (Charophyta) v mělkých vodních ekosystémech ČSSR. [Charophyta in shallow water ecosystem in the ČSSR]. - In: Zborník VII. Konferencie Čs. Limnologické Společnosti, Nitra, DT ČSVTS Žilina. - pp. 165-168.

Husák, Š. (2001): Vegetace parožnatek (Charophyceae vegetation). - In: ChytrÝ, M., KuČERA, T. \& KoČí, M. (eds): Katalog biotopů České republiky. - pp. 23-25 pp., Agentura ochrany př́rody a krajiny ČR, Praha.

Hy, F. (1889): Sur les modes de ramification et de cortication dans la famille des Characées, et les caractéres qu'ils petent fournir á la classification. - Bulletin de la Société Botanique de France 36: 393-398.

Irvine, D.E.G. \& JoHn, D.M. (1984): Systematics of the green algae. - Academic Press 7: 206-232.

John, D.M. \& Moore, J.A. (1987): An SEM study of the oospore of some Nitella species (Chlorophyta, Charales) with descriptions of wall ornamentation and an assessment of its taxonomic importace. - Phycologia 26: 334355.

John, D.M., Moore, J.A. \& Green, D.R. (1990): Preliminary observations on the structure and ornamentation of the oosporangial wall in Chara (Charales, Charophyta). - British Phycology Journal 25: 1-24.

Kapralov, M.V. \& Filatov, D.A. (2007): Widespread positive selection in the photosynthetic Rubisco enzyme. - BMC Evolutionary Biology 7: 73.

Karol, K.G., McCourt, R.M., Cimino, M.T. \& Delwiche, C.F. (2001): The closest living relatives of land plants. - Science 294: 23512353.

KHAN, M. \& SARMa, Y.S.R.K. (1984): Cytogeography and cytosystematics of Charophyta. - In: Irvine, D.E.G. \& John, D.M. (eds): Systematics of the Green Algae. - pp. 303-330, Academic Press London and Orlando.

Krause, W. (1981): Characeen als Bioindikatoren für den Gewässerzustand. - Limnologica 13: 399_ 418.

Krause, W. (1997): Charales (Charophyceae). In: Ettl, H., Gärtner, G., Heynig, H. \& Mollenhauer, D. (eds): Süsswasserflora von Mittleuropa 18. - pp. 1-202, Gustav Fischer Verlag, Jena.

Leitch, A.R., John, D.M. \& Moore, J.A. (1990): The oosporangium of the Characeae (Chlorophyta, Charales). - Progress in Phycological Research 7: 213-268.

Leonhardi, (P. C. P. G.) H. Von (1863): Über die böhmmischen Characeen. - Lotos 13: 55-62, 69-80, 110- 111 .

LhотsкÝ, O. \& RosA, K. (1955): Soupis moravskoslezských sinic a řas [Verzeichnis der Mährisch - Schlesischen algen]. - 260 pp., Nakladatelství Československé akademie věd, Praha.

LinNAuEs, C. (1753): Species Plantarum, eorumque characters naturales secundum numerum, figuram, situm et proportion omnium fructificationis partium. ed. 5. Holmiae. [Chara, p. 491].

MandAL, D.K.\&RAY, S.(2004): Taxonomic significance of micromorphology and dimensions of oospores in the genus Chara L. (Charales, Chlorophyta). - Archives of Biological Sciences, Belgrade 56: 131-138.

Martín-Closas, C. (2003): The fossil record and evolution of freshwater plants: (A review). Geologica Acta 1: 315-338.

Mattox, K.R. \& Stewart, K.D. (1984): Classification of the green algae: a koncept based on komparative cytology. - In: Irvine, D.E.G. \& John, D.M. (eds): Systematics of the green algae. - pp. 29-72, Academic Press, London.

McCourT, R.M. (1995): Green algal phylogeny. Trends in Ecology and Evolution 10: 159-163.

McCourt, R.M., Karol, K.G., Guerlesquin, M \& FeIst, M. (1996): Phylogeny of extant genera in the family Characeae (Charales, Charophyceae) based on rcbL sequences and morphology. American Journal of Botany 83:125-131.

McCourt, R.M., Karol, K.G., Kaplan, S. \& Hoshaw, R.W. (1995): Using rbcL sequences to test hypotheses of chloroplast and thallus evolution in conjugating green algae (Zygnematales, Charophyceae). - Journal of Phycology 31: 989-995.

Meiers, S.T., Proctor, V.W. \& Chapman, R.L. (1999): Phylogeny and biogeography of Chara (Charophyta) inferred from 18S rDNA Sequences. - Aust Journal of Botany 47: 347360.

Melkonian, M. \& Surek, B. (1995): Phylogeny of the Chlorophyta: Congruence between ultrastructural and molecular evidence. Bulletin de la Societe Zoologique de France 120: 191-208.

MigulA, W. (1897, 1890-1897): Die Characeen Deutschlands, Oesterreichs und der Schweiz; Unter Berücksichtigung aller Arten Europas. In: Rabenhorst, L. (ed.): Kryptogamenflora von Deutschland, Oesterreich und der Schweiz. 2. Aufl. Vol. 5. - 765 pp., Verlag Eduard Kummer, 
Leipzig.

Migula, W. (1897): Die Characeen. - In: Rabenhorst, L. (ed.): Kryptogamenflora von Deutschland, Osterreich und der Schweiz. - 765 pp., Kummer, Leipzig.

Mishler, B.D. \& Churchill, S.P. (1985): Transition to a land flora: phylogenetic relationshops of the green algae and bryophytes. - Cladistics 1: 305-328.

Mukherjee, A. \& Ray, S. (1993): Scanninng electron microscopic study of compound oospore wall ornamentations of some charophyte taxa from West Bengal. - Phytomorphology 43: 111116.

Opiz, M. (1852): Seznam rostlin květeny české. -216 pp., Praha.

PeŁechaty, M., Pukacz, A. \& Pelechata, A. (2004): Co-occurrence of two stoneworts of reverse ecological spectra in the same lake ecosystem. Habitat requirements of Chara delicatula AgARDH and Chara globularis THUILLIER in the context of bioindication. - Polish Journal of Environmental Studies 13: 551-556.

PoulíčKovÁ, A., LhotskÝ, O. \& DřímalovÁ, D. (2004): Prodromus sinic a řas ČR. - Czech Phycology 4: $19-33$.

PresL, J. (1846): Všeobecný rostlinopis. - Praha, II. svazek.

Printz, H. (1927): Chlorophyceae. - In: Engler, A. \& Prantl.K.(eds):DienatürlichenPflanzenfamilien nebst ihren Gattungen und wichtigeren Arten insbesondere den Nutzpflanzen. - pp. 412-429, Leipzig Verlag von Wilhelm Engelmann.

Proctor, V.W. (1975): Phycologial reviews 2. The nature of charophytes species. - Phycologia 14: 97-113.

Ray, S., Pekkari, S. \& Snoeiss, P. (2001): Oospore dimensions and wall ornamentation patterns in Swedesh charophytes. - Nordic Journal of Botany 21: 207-224.

RupreChT, F.J. (1845): Distributio Cryptogamarum Vascularium in Imperio Rossico. Petropoli. [Characeae, pp. 7-18: C. glomerulifera, C. commutate, $C$. interrupta, $C$. longifurca, $C$. condensate, C. eremosperma, C. spinosa VAILLANTII.]

SAKayAma, H. (2008): Taxonomy of Nitella (Charales, Charophyceae) based on komparative morfology of oospores and multiple DNA marker phylogeny using cultured material. Phycological Research 56: 202-215.

Sakayama, H., Arai, S., Nozaki, H., Kasai, F. \& Watanabe, M.M. (2006): Morphology, molecular phylogeny and taxonomy of Nitella comptonii (Charales, Characeae). - Phycologia 45: 417-421.

Sakayama, H., Nozaki, H., Kasaki, H. \& Hara, Y. (2002): Taxonomic re-examination of Nitella
(Charales, Charophyceae) from Japan, based on microscopical studies of oospore wall ornamentation and $\mathrm{rbcL}$ gene sequences. Phycologia 41: 397-408.

SAWA, T. (1974): New chromosome numbers for the genus Tolypella. - Bulletin of the Torrey Botanical Club 101: 21-26.

SAWA, T. \& Frame, P.W. (1974): Comparative anatomy of Charophyta. I. Oogonia and oospores of Tolypella - with special reference to the steril oogonial cell. - Bulletin of the Torrey Botanical Club 101: 136-44.

SCHEFFER, M. (1989): Alternative stable states in eutrophic freshwater systems. A minimal model. - Hydrobiology Bulletin. 23: 73-83.

Scheffer, M. \& JEPPESEN, E. (1998): Alternative stable states. - In: Jeppesen, E., SøndergaArd, M., SøndergaArd, M. \& Christoffersen, K. (eds): The structure role of submerged macrophytes in lakes/ Ecological Studies 131. - pp. 387-406, Springer, New York.

Scheffer, M. (2001): Ecology of shallow lakes. - 356 pp., Kluwer Academic Publishers.

Soulié - Märsche, I. (1989): Etude comparée de gyrogonites de Charophytes actuelles et fossiles et phylogénie des genres actuels. - 237 pp., Thése-és-Sci.Université des Sciences et Techniques du Languedoc, Montpellier, Thêse d'Etat.

Stewart, K.D. \& Mattox, K.R. (1975): Comparative cytology, evolotion and classification of the green algae with some consideration of the origin of other organisms with chlorophylls a and b. - Botanical Review 41: 104-135.

Surek, B., Beemelmanns, U., Melkonian, M. \& Bhattacharya, D. (1993): Ribosomal RNA sequence comparisons demonstrate an evolutionary relationship between Zygnematales and Charophytes. - Plant Systems and Evolution 191: 171-181.

Torn, K., Martin, G., Kukk, H. \& Trei, T. (2004): Distribution of charophyte species in Estonian coastal water (NE Baltic Sea). - Scientia Marina 68: 129-136.

URBANIAK, J. (2007a): Distribution of Chara braunii Gmellin 1826 (Charophyta) in Poland. - Acta Societatis Botanicorum Poloniae 76: 313-320.

URBANIAK, J. (2007b): Differences in morphology and oospore wall ornamentation in Nitella gracilis (Smith) Agardh 1828 and Nitella mucronata (A. Braun) Miquel 1840 (Charales, Charophyceae) from Poland. - Biologia, in press.

Urbaniak, J., GĄBKA, M. \& BlažEnIC, J. (2008): Nitella tenuissima, a rare Charophyte in Central and Southern Europe. - Cryptogamie, Algologie 29: 161-171.

Vaillant, S. (1721): Caractéres de katorze genus de plantes. - Memory Academy of Royal Sciences 
Paris (1719): 17-20.

Van Den Berg, M.S., Scheffer, M., Coops, H. \& Simons, J. (1998): The role of Characean algae in the management of eutrophic shallow lakes. - Journal of Phycology 34: 750-756.

Van Den Berg, M.S., Scheffer, M., Mannes, E. \& Coops, H. (1999): Dynamics and stability of Chara sp. and Potamogeton pectinatus. Hydrobiologia 408/409: 335-342.

Vilhelm, J. (1914): Monografická studie o českých parožnatkách. [Bohemian Characeen.] Věstník Královské České Společnosti Nauk. [or Mém. Soc. Roy. Sci. Boheme (1914) (2): 1-168, 41fig.] [Czechoslovakian].

Vilhelm, J. (1922): Novae species et formae Characearum I. Characeae bohemicae. Hedwigia, Bd. LXIV.: 148-163.

Vilhelm, J. (1925): Třetí příspěvek $\mathrm{k}$ výzkumu českých parožnatek v r. 1922-1924. - Časopis Národního musea: 20-25.

Wood, R.D. (1962): New combinations and taxa in the revision of Characeae. - Taxon 11: 7-25.

Wood, R.D. \& IMAHori, K. (1965): A revision of the Characeae. Monograph of the Characeae. -904 pp., J. Cramer Verlag, Weinheim.

Zatoń, M., Piechota, A. \& Sienkiewicz, E. (2005): Late triassic charophytes around the bone - bearing bed at Krasiejów (SW Poland) palaeoecological and environmental remarks. - Acta Geologica Polonica 55: 283-293.

\section{Attachment \\ List of Czech charophytes and their localities (supplement to distribution maps)}

Fig. 13. Chara aspera in the Czech Republic.

Locations: Kersko near Sadská (collected by VelenovsKÝ in 1883 and by KLIKA in 1929); Kostomlaty near Nymburk (collected by PolÁK in 1880); near Oužice (collected by ČelakovsKÝ in 1880, by TOCL in 1895, by PodPěra in 1899 and by JIRSÁK in 1899); Rečkov near Bělá pod Bezdězem (collected by VILHELM in 1899); Neratovice (collected by VILHELM in 1901); near Doksy (collected by VILHELM in 1901); Bakov nad Jizerou (VILHelm 1914); Bezdružice (Vilhelm 1925); Bohdaneč (Vilhelm 1914); Polabí (Vilhelm 1914); Hranov near Lysá nad Labem (collected by KLIKA in 1929); Netřeby (collected by JIRSÁK in 1930); Lysá nad Labem (collected by DostáL in 1940); Rozkoš near Bohdaneč (collected by OpIz in 1853); Čejč (LHOTSKÝ \& Rosa 1955); Lednice (LHOtsKÝ \& Rosa 1955); Kobylí (LHOTsKÝ \& Rosa 1955); Sedlec (LHотsкÝ \& Rosa 1955); Valtice (LHотsкÝ \& Rosa 1955); pond Břehyňský (collected by Husák in 1989).

Fig. 22. Chara braunii in the Czech Republic.

Locations: Františkovi Lázně (collected by BRACHT in 1839); Prasetice near Teplice (collected by EICHLER in 1854); Duchcov (collected by Reuss in 1862); Čekanice (collected by VelENOvSKÝ in 1876); Nový Bydžov (collected by ČELAKOVSKÝ in 1876); Sedlice (collected by VelenOVSKÝ in 1876); Blatná (collected by ČELAKOVSKÝ in 1876 and by ŠTĚPÁN in 1913); Klatovy (collected by ČELAKOVSKÝ in 1879);
Plzeň (collected by Hora in 1882); Skochovice near Vrané nad Vltavou (collected by PoDPĚra in 1896); Třeboň (collected by VILHELM in 1899); pond Rožmberk near Třeboň (collected by VILHELM in 1899); Staré Hasiny near Rožd'alovice (collected by Vilhelm in 1909); Pečice (collected by VilHelm in 1911); pond near Pozd'atín (collected by Dvoř́́K in 1913); Hluboká nad Vltavou (VILHelm 1914); Prague (VILHelm 1914 and by OpIZ in 1823); Vodňany (collected by ŠTĚPÁN in 1922); Mariánské Lázně (collected by OpIz in 1823); near Prague (collected by OpIz in 1823); pond in forest Královská Obora near Prague (collected by OpIz in 1824); Vrbno near Blatná (collected by VILHELM in 1930); pond near Karviná, Bohumín (collected by ŠMARDA in 1950); near Studénka (collected by DAMBSKKA in 1952); Hvězdoňovice (LHOTSKÝ \& Rosa 1955); Náměšt' nad Oslavou (Lhotský \& Rosa 1955); Pozd'atín (LHotskÝ \& Rosa 1955); Brno (collected by DąmBSKa in 1958); pond Radov near Blatná (collected by DĄMBSKA in 1958); Libějovice (collected by HeJNÝ in 1961); pond Záblatíčko near Vodňany (collected by HEJNÝ in 1961); near Radomilice, Vodňany region (collected by HesNÝ in 1961); Chvalešovice, Vodňany region (collected by HeJNÝ in 1961 and in 1964); pond Nesyt, Mikulov region (collected by HEJNÝ in 1962); pond Doktorovský near Vodňany (collected by HeJNÝ in 1962); near Sudoměř u Bechyně (collected by HeJNÝ in 1962); pond Záblatský, Hluboká nad Vltavou (collected by HeJNÝ in 1962 and 1964); near Dívčice (collected by HeJNÝ in 1964); Mydlovary, Hluboká nad Vltavou region (collected by HeJNÝ in 1964); pond Talinský, Písek region (collected by HeJNÝ in 1964); between Protivín and Nová Ves (collected by HeJNÝ in 1964); Mladějovice near Strakonice (collected by HEJNÝ in 1964); pond Řežabinec near Ražice (collected by HesNÝ in 1968); pond Dolní Rybník near Novosedly, České Budějovice region (collected by Vydrová in 1994); fish keep Stř́břec, Třeboň region (collected by ŠuMBEROVÁ in 2002); fish keep near pond Košináŕ, Plzeň (collected by Šumberová in 2002); pond Pařezitý, Budínek, Př́ibram region (collected by RYDLO in 2003); pool near stream Čermná, near Borohrádek, Pardubice region (collected by SKÁCElová in 2004); Lomnice nad Lužnicí (PoulíčKovÁ et al. 2004); Lužnice (PoulíčKová et al. 2004); Mladá Boleslav (PoulíčKovÁ et al. 2004); fish keep no 20 and 42, Hluboká nad Vltavou (collected by Šumberová in 2007); fish keep (small ponds); Rudolfov near České Budějovice (collected by ŠumBEROVÁ in 2008); fish keep near pond Lhotka, Lhotka, Novohradsko region (collected by ŠuMBEROVÁ in 2008).

Fig. 30. Chara canescens in the Czech Republic.

Locations: Poděbrady (collected by PÁTEK in 1880 and by VelenovsKÝ in 1881); near Neratovice (collected by ČElaKovsKÝ in 1875); Oužice near Kralupy nad Vltavou (collected by ČELAKOVSKÝ in 1875 , by TONCL in 1895, 1896); Šumava region (collected by BílÝ in 1927); Čejč (collected by Bílý in 1927); Valtice (LhotskÝ \& Rosa 1955); Lednice (PoulíčKová et al. 2004); Netřeby (PoulíčKovÁ et al. 2004).

Fig. 38. Chara connivens in the Czech Republic.

Locations: Krč, Prague region (collected by PoLÁK in 1874); Jaroměř near Dvưr Králové (collected by ČELAKOvSKÝ in 1875); near Hradec Králové (collected by ToncL in 1895); Pardubice (collected by TONCL in 1896); near Třeboň (collected by VILHELM in 1899); Neratovice (collected by VILHELM in 1900); near Doksy (collected by VILHELM in 1901); Doksy (collected by VILHELM in 1902); Praque region (VILHelm 1914); Chlum near Třeboň (collected by Bílý in 1927); Brno (Lhotský \& Rosa 1955); Bukovka, Pardubice 
region (LhotskÝ \& Rosa 1955); Dobřany (LHOTsKÝ \& RosA 1955); near Brno (LHOtskÝ \& Rosa 1955); Přeštice (LHOTSKÝ \& Rosa 1955); Valtice (Lhotský \& Rosa 1955); between Lednice and Podivín, Plzeň region (collected by HeJNÝ in 1958).

Fig. 47. Chara contraria in the Czech Republic.

Locations: Bělá pod Bezdězem (collected by VILHELM in 1864); Liberec (collected by VILHELM in 1864); Starkoč near Skalice (collected by DĚDEČEK in 1871); pond Močický near Mladá Boleslav (collected by WILUCKY in 1876 and by VILHELM in 1911); Jičín (collected by SITENSKÝ in 1880); between Doksy and Jestřebí (collected by SiTENSKÝ in 1880 and VILHELM in 1901); Doksy (collected by VILHELM in 1901 and 1923); Staré Hasiny near Rožd'alovice (collected by VILHELM in 1909); between Byšice and Všetaty (collected by VILHELM in 1911); pond near Jesenice (collected by ŠTĚPÁN in 1913); Všetaty (collected by ČELAKOVSKÝ in 1922); Lednice (Lhotský \& Rosa 1955); Měnín (Lhotský \& Rosa 1955); Mohelno (LhotskÝ \& Rosa 1955); Nová Ves near Oslavany (LHotský \& Rosa 1955); Sedlec (Lhotský \& Rosa 1955); Sokolnice (LHOtsкÝ \& Rosa 1955); Valtice (LHOTsкÝ \& Rosa 1955); pond Nesyt near Mikulov (collected by HeJNÝ in 1962); Česká Skalice (PoulíčKová et al. 2004); Prachovské skály (PoulíčKovÁ et al. 2004); Rožd’alovice (PoulíčKovÁ et al. 2004); Starkoč near Česká Skalice (PoulíčKovÁ et al. 2004); fish keep no 3, Staré Hrady near Libáň, Jičín region (collected by ŠumBEROVÁ in 2008).

Fig. 56. Chara delicatula in the Czech Republic.

Locations: Prague (collected by SNOPŘEHLASBL in 1854); Hradec Králové (collected by PolÁK in 1874); near Doksy (collected by VILHELM in 1901); pond Proudnický, Chlumec nad Cidlinou region (collected by VILHELM in 1901); Neratovice (collected by VILHELM 1914); pond Pročencký near Milotice, Kyjov region (collected by BíLÝ in 1927); pond Milotice, Kyjov region (collected by Bílý in 1927); Brno (LhotskÝ \& Rosa 1955); Lhota pod Libčany near Hradec Králové (LhotskÝ \& Rosa 1955); near Č́áslav (LhotskÝ \& Rosa 1955); Nové Město (Lhotský \& Rosa 1955); Vyškov, near Boskovice (LнотsкÝ \& Rosa 1955); fish keep no 18, Hluboká nad Vltavou (collected by ŠuMBEROvá in 2002); fish keep near pond Trnov, Čejetice, Strakonice region (collected by Šumberová in 2002); pool near Pavlov, Drahanská vrchovina (collected by JAN RYDLO \& JAROSLAV RYdLO in 2007); pond near Chot'ovice, Nymburk region (collected by JAROSLAV RYDLO in 2008).

Fig. 65. Chara globularis in the Czech Republic.

Locations: pond Broumec, Opočno (collected by ČELAKOVsKÝ in 1818); Dačice (collected by MANN in 1820); Karlovy Vary (collected by Reuss in 1839); Hluboká nad Vltavou (collected by PURKYNĚ in 1849); pond Rozkoš near Bohdaneč (collected by OpIZ in 1849); near Roudnice (collected by Reuss in 1861); Libochovice near Mělník (collected by Reuss in 1864); Bělá pod Bezdězem (collected by HiPPeLli in 1864 and by VILHELM in 1899); Třebechovice pod Orebem (collected by Leonhardi in 1865); Chuchle near Prague (collected by LEONHARDI in 1866); Prague (collected by LEONHARDI in 1866 and by STEHLÍK in 1921); Doksy (collected by Šouta in 1867); Poděbrady (collected by ČELAKOvSKÝ in 1867); Brandýs nad Orlicí (collected by ČELAKOvSKÝ in 1868); near Benátky (collected by DĚDEČEK in 1870, 1872); Teplice (collected by DĚDEČEK in 1870); Starkoč near Česká Skalice (collected by DĚDEČEK in 1871); Roztoky near Prague (collected by DĚDEČEK in 1872); Teplice (collected by DĚDEČEK in 1872); Putim near Písek (collected by DĚDEČEK in 1873); Nymburk (collected by ČELAKOVSKÝ in 1877); pond Broumar near Opočno (collected by ČELAKOVSKÝ in 1878); Jičín (collected by SITENSKÝ in 1880); Kostomlaty near Nymburk (collected by PoLÁK in 1880); Osečná near Liberec (collected by SitENSKÝ in 1880); Cečelice (collected by VelenovsKÝ in 1881); near Čečelice (collected by VeLENOVSKÝ in 1881); Mladá Boleslav (collected by PODPĚRA in 1881); Velké Kostomlaty (collected by ČELAKOVSKÝ in 1881); Lysá nad Labem (collected by VelenovsKÝ in 1882); Doubice near Sadská (collected by VelenovskÝ in 1883); Sedlčany (collected by VelenovskÝ in 1883); Liblice (collected by Velenovský in 1884); Lysá (collected by VelenovskÝ in 1886); Chudenice (collected by RoubaL in 1898); Plzeň (collected by PетRвоK in 1898); Byšice (collected by VilHeLm in 1899); Rečkov near Bakov (collected by VILHELm in 1899); Týniště (collected by RoHLEna in 1899); Putim (collected by RADBA in 1900); Doksy (collected by VILHELM in 1901); Neratovice (collected by VILHELM in 1901); Všetaty-Byšice (collected by ViLhelm in 1901, 1902, 1913, 1920); Hrabanov near Lysá nad Labem (collected by VILHELM in 1902); Vavřinec (collected by VILHELM in 1902); Všetaty near Mělník (collected by VILHELM in 1902); pools near Povel, Olomouc region (collected by PoDPĚra in 1904 and 1907); Č́slav (collected by NovÁK in 1909); Jinolice near Jičín (collected by BAUDYš in 1911); near Velká Lhota (collected by BAUDYš in 1911); Pečice near Mladá Boleslav (collected by VILHELM in 1911); pond Hluboký near Chudír (collected by VILHELM in 1911); pool near Sokolnice (collected by Dvoř́K in 1912); pond near Sychrov (collected by VILHELm in 1913); Sychrov (collected by Vilhelm in 1913); Český Krumlov (VILHELM 1914); Písek (VIlhelm 1914); near Radotín (collected by SCHUSTLER in 1915); near Hradec Králové (collected by HANSGIRG in 1918); pool near Mohelno (collected by DvoŘÁK in 1920); Nová Ves near Týniště nad Orlicí (collected by ROHLENA in 1921); Nové Dvory (collected by KLÁŠTERSKÝ in 1921); Uherský Brod (collected by SтEнLí in 1921); Volšina near Týniště nad Orlicí (collected by RoHLEna in 1921); Žamberk (collected by RoHLENA in 1921); pond Velký, Doksy (collected by VILHeLm in 1923); pool near Jizera, Nové Benátky (collected by DĚDEČEK in 1923); wetland Čaganovské near Bzenec (collected by BíLÝ in 1924); Poříčany (collected by KLIKA in 1924); Brzovany near Louny (collected by KLIKA in 1926); Neratovice (collected by JIRSÁK in 1937); pond Řežabinec, Velká Ves (collected by JiRSÁK in 1938); Janová, Vsetín region (collected by Pospíšil in 1948); pool between Rakvice nad Dyje, Břeclav region (collected by ČERNOCH in 1949); Bílé Karpaty (LHotskÝ \& Rosa 1955); Brno (LHотsкÝ \& Rosa 1955); Hradiště (Lhotský \& Rosa 1955); Hranice (LHOTSKÝ \& Rosa 1955); Lednice (LHOTSKÝ \& Rosa 1955); Milotice (LHOTsKÝ \& Rosa 1955); Náměšt’ nad Oslavou (LHotskÝ \& Rosa 1955); Olomouc (LHotskÝ \& Rosa 1955); Svitavy (LhotskÝ \& Rosa 1955); Nový Valdek (Lhotský \& Rosa 1955); Teplice (Lhotský \& Rosa 1955); Valtice (LhotskÝ \& Rosa 1955); Ražice (collected by SKaLICKÝ in 1955); Milešov (collected by SKaLICKÝ in 1956); pond Ostrovec near Pozd'atín (collected by DĄBSKA in 1959); pond near Tábor (collected by DĄMBSKA in 1958); pond Řežabinec near Písek (collected by DĄMBSKA in 1958); pool near pond Kupcov, Blatná (collected by DĄMBSKA in 1958); peat bog near Veselí nad Lužnicí (collected by DA_mBSKA in 1958); pond Zámecký near Hluboká nad Vltavou (collected by DĄMBSKA in 1958); pond Zámecký, Lednice (collected by DĄMBSKA in 1958); Radomilice, Vodňany region (collected 
by HeJNÝ in 1961); Malovice, Vodňany region (collected by HeJNÝ in 1961); Chvalešovice, Vodňany region (collected by HeJNÝ in 1962); Česká Lípa region (collected by KostKová \& Jaroslav Rydlo in 1987); pond Prostřední, Nový Jáchymov, Krrivoklát region (collected by KostKOVÁ \& JAROSLAV RYDLO in 1987); pond in forest near Čelákovice (collected by JAROSLAV RYDLO in 1988); pond Břehyňský, Kostomlaty nad Labem (collected by JAROSLAV RYDLO in 1990); pond near stream Hořanský, Hořany near Kutná Hora (collected by JAROSLAV RYDLO in 1993); Č́ízov, Znojmo region (collected by JAROSLAV RYDLO in 1994); Záhořice (collected by JAROSLAV Rydlo, Stanová \& TrávníčEK in 1995); Královský Chlumec (collected by HeJnÝ in 1955); ponds, Chotobuz, Průhonice (collected by HaAsová in 1995); Vápensko, Nymburk region (collected by Jaroslav Rydlo in 1996); sand mine near Branná, Třeboň region (collected by HusÁK in 1997); pond Oběšenec, Březina, Český ráj region (collected by JAROSLAV RYDLO \& VACKOVÁ in 1997); Úžice, Mělník region (collected by Jaroslav Rydlo in 1997); near pond Osí, Boletice, Český Krumlov region (collected by VYDrovÁ in 1997); Podvoří Boletice, Český Krumlov region (collected by VYDROVÁ in 1997); pond Krčák, Želejov, Český ráj region (collected by JAROSLAV RYDLO in 1998); near Sokoleč, Nymburk region (collected by Jaroslav Rydlo in 1999); Rozkoš, Nymburk region (collected by JAROSLAV RYDLO in 2000); Kouty, Nymburk region (collected by JAROSLAV RYdLO in 2000); Horecké písníky near Bohdaneč, Pardubice region (collected by SKÁCElOVÁ in 2001); pond Bohdanečský, Pardubice region (collected by SKÁCELOVÁ in 2001); ditch near Zaječí, Lednice region (collected by SKÁcelová in 2001); dump, Sokolov region (collected by SKÁCELOVÁ in 2001); pond in Dolní Kersko, Nymburk region (collected by JAROSLAV RYDLO in 2001); fish keep, Střehom, Mladá Boleslav region (collected by Šumberová in 2002); fish keep near pond Velký Záhumenný, Charvatce, Jičín region (collected by ŠuMBERovÁ in 2002); pond Alah 1 and Alah 4, Hlohovec, Břeclav region (collected by JAROSLAV RYDLO in 2002 and by HusáK in 2002); Mušov, Břeclav region (collected by JAROSLAV RYDLO in 2002); pond Sladovník, Loučeň, Nymburk region (collected by JAROSLAV RYDLO in 2002); pond Knížecí, Loučeň, Nymburk region (collected by JAROSLAV RYDLO in 2002 and 2004); pond in forest Žehuňský, Kněžičky, Nymburk region (collected by JAROSLAV RYDLO in 2002); Milčice, Nymburk region (collected by JAROSLAV RYDLO in 2002); Kostomlaty nad Labem (collected by JAROSLAV RYDLO in 2002); near Cítov, Mělník region (collected by JAROSLAV RYDLO in 2003); sand pit near Tišice, Mělník region (collected by JAROSLAV RYDLO in 2003); pond near Stará Hasina, Nymburk region (collected by Jaroslav Rydlo in 2004); Malý Nouzov, Nymburk region (collected by JAROSLAV RydLO in 2004); pond Nehetník, Dvůr Skalka, Příbram region (collected by JAROSLAV RYDLO in 2004); Bakov nad Jizerou (PoulíčKovÁ et al. 2004); Bečov nad Teplou (PoulíčKovÁ et al. 2004); České Budějovice (PoulíčKová et al. 2004); Česká Skalice (PoulíčKovÁ et al. 2004); Lužnice (PoulíčKovÁ et al. 2004); Mělník (PoulíčKová et al. 2004); Mělnická Vrutice (PoulíčKová et al. 2004); Polabí (PoulíčKová et al. 2004); Prachovské skály (PoulíčKová et al. 2004); Prague (PoulíčKovÁ et al. 2004); Osečná near Liberec (PoulíčKovÁ et al. 2004); Třeboň (PoulíčKová et al. 2004); Turnov (PoulíčKovÁ et al. 2004); Veselí nad Lužnicí (PoulíčKovÁ et al. 2004); pond Dražský, Malá Buková, Př́bram region (collected by JAROSLAV RYDLO in 2005); Velim, Kolín region (collected by JAROSLAV RYDLO in 2005); pool in forest Sánský, Opolany, Nymburk region (collected by JAROSLAV RYDLO in
2006); Hrabanovská Černava, near Lysá nad Labem (collected by Formanová, Husáková, Molíková \& Jaroslav Rydlo in 2006); fish keep no 42, Hluboká nad Vltavou (collected by Šumberová in 2007); pond Matha near Pardubice (collected by Formanová in 2007); pond in Horní Lockov, Český ráj (collected by JAROSLAV RYDLO \& VACKOVÁ in 2007); Žehrov, Český Ráj region (collected by JAROSLAV RYdLo \& VACKOVÁ in 2007); ponds near wetland Pavlovský, Drahanská vrchovina region (collected by JAROSLAV RYDLO \& JAN RYDLO in 2007); Vranov nad Dyjí (collected by ReItrovÁ, JARosLAV RYDLO \& JAN RYDLO in 2007); Pavlov, Drahanská vrchovina region (collected by JAROSLAV RYDLO \& JAN RYDLO in 2007); pond Čekál, Olbram Kostel (collected by Bravencová, Reiter, Jaroslav Rydlo \& JAN Rydlo in 2007); near pond Týnský, Rakšice, Znojmo region (collected by BRAVENCOVÁ, ReIter, JarosLaV Rydlo \& JAN RYdLO in 2007); pond Rokytnický, Rokytnice, Český Ráj region (collected by JAROSLAV RYDLO \& JAN RYDLO in 2007); pond Suchohrdelský, Suchohrdly, Znojmo region (collected by BravencovÁ, ReITER, JAROSLAV Rydlo \& JAN Rydlo in 2007); Borkovice (collected by KouteckÝ in 2008); Choryně (collected by KOUTECKÝ in 2008); near Sokolov (collected by HaUER in 2008); Smědeč (collected by VydrovÁ in 2008); Třebín (collected by KOUTECKÝ in 2008); Zliv (collected by KouteCKÝ in 2008); Hustopeče nad Bečvou (collected by JAROSLAV RYDLO \& BARTOŠOVÁ in 2008); Křepice, Znojmo region (collected by Bartošová, JAN RYdLO \& JAROSLAV RYDLO in 2008); complex of ponds, Černá v Pošumaví, Bohemia Forest region (collected by ŠuMBEROVÁ in 2008); fish keep (small ponds); Rudolfov near České Budějovice (collected by Šumberová in 2008); fish keep no 53 and 54, Hluboká nad Vltavou (collected by ŠumBEROVÁ in 2008); pool Genžová in forest Boří, Břeclav region (collected by Šumberová in 2008); pool "Ve stovce" in forest Boří, Břeclav region (collected by ŠuMBEROVÁ in 2008); pool near Beníkovice and Boletice, Český Krumlov region (collected by GrULICH \& VYDROVÁ in 2008).

Fig. 76. Chara gymnophylla in the Czech Republic.

Locations: Bělá pod Bezdězem (collected by VILHELM in 1899); Neratovice (collected by VILHELM in 1900); near Doksy (collected by VILHELM in 1901); Doksy (collected by VILHELM in 1902); Polabí region (collected by VILHELM in 1907); Bakov nad Jizerou (VILHelm 1914); Bohdaneč (Vilhelm 1914); near Bezdružice (VILhelm 1925); Hranov near Lysá nad Labem (collected by KLIKA in 1929); Netřeby (collected by JiRSÁK in 1930); Břeclav (LHOTSKÝ \& RosA 1955); Valtice (LнотsкÝ \& Rosa 1955).

Fig. 82. Chara hispida in the Czech Republic.

Locations: Všetaty (collected by ČELAKOVSKÝ in 1881, 1882, by PODPĚra in 1814, by VILHELM in 1901, 1911, 1913, by VelenovsKÝ in 1912, by KLIKA in 1930, by JAROSLAV RydLO in 2002 ); Lysá nad Labem (collected by VelenOvsKÝ in 1883 and 1886, by Vilhelm in 1899 and by Dostál in 1940); Nymburk (collected by OPIz in 1833); near Nymburk (collected by VeLENOVSKÝ in 1883); near Liblice (collected by VelenOVSKÝ in 1884); Kostomlaty nad Labem (collected by VelenOVSKÝ in 1885 and by JAROSLAV RydLO \& VydRovÁ in 2007); near Lysá nad Labem (collected by VelEnOvsKÝ in 1886); pool near Dubňany, Prague (collected by VelenovskÝ in 1886); Vratice (collected by ČELAKOVSKÝ in 1888); Hrabanov near Lysá nad Labem (collected by VILHELM in 1899 and by KLIKA in 1929); Neratovice (collected by Vilhelm in 1901, by Pertbok in 1912 and by JaroslaV 
RYDLO in 2004); Dubňany (collected by Bílý in 1924 and Lhotský \& Rosa 1955); pool, Dubňany near Kyjov dump, Sokolov region (collected by Bílý in 1924); near stream Dunávka near Opatovice (collected by Bílý in 1924); lake Čejčské (collected by BílÝ in 1927); Rakvice near Podivín (collected by BíLÝ in 1927); Neratovice (collected by JIRSÁK in 1932); Prague (collected by JIRSÁK in 1932); Netřeby near Kralupy nad Vltavou (collected by JIRSÁK in 1938); ditch near Nesvačilka (collected by BíLÝ in 1938); Kobylí (Lhotský \& Rosa 1955); Přerov (Lhotský \& Rosa 1955); dumps Albrechtická, Most (collected by KostKová in 1988); Viničná Lhota, Nymburk region (collected by JAROSLAV RYDLO in 1988); sand pit near Hradiště, Znojmo region (collected by JaRoslaV Rydlo in 1992); Mělnická Vrutice (collected by JAROSLAV RYDLO in 1999); near Kouty, Nymburk region (collected by JAROSLAV RYDLO in 1995 and 2000); pond near Kostomlaty nad Labem, Nymburk region (collected by JAROSLAV RYDLO in 2000 and in 2002; pond near Nymburk (collected by JAROSLAV RYDLO in 1990); pond Budiměřice, Nymburk region (collected by JAROSLAV RYDLO in 1995 and 2001); stone pit near Blansko, Moravia region (collected by SKÁCELOVÁ in 2001); lake near Vacenovice, Moravia region (collected by SKÁCELOVÁ in 2001 and 2007); Hrabanov, Lysá nad Labem (collected by JAROSLAV RYDLO in 2002); near Cítov, Mělník region (collected JarosLaV Rydlo in 2003); sand pit near Lenešice, Louny region (collected by JAROSLAV RYDLO in 2004); Velim, Kolín region (collected by JAROSLAV RYDLO in 2004 and 2005); Kralupy nad Vltavou (PoulíčKovÁ et al. 2004); Mělník (PoulíčKová et al. 2004); Milovice (PoulíčKovÁ et al. 2004); Oužice near Kralupy nad Vltavou (PoulíčKovÁ et al. 2004); Pardubice (PoulíčKOvÁ et al. 2004); Poděbrady (PoulíčKová et al. 2004); Polabí (PoulíčKová et al. 2004); Hrabanovská Černava, Lysá nad Labem, Nymburk region (collected by Formanová, Husáková, Molíková \& JaroslaV Rydlo in 2006); pond Písečný, Milotice (collected by VYDROVÁ in 2008).

Fig. 91. Chara intermedia in the Czech Republic. Locations: Krutica near Lysá nad Labem (collected by VelENOVSKÝ in 1884); near Čejč (collected by BílÝ in 1927); Čejč (LhotskÝ \& Rosa 1955); Lysá nad Labem (PoulíčKovÁ et al. 2004).

Fig. 99. Chara polyacantha in the Czech Republic. Locations: Hrabanov near Lysá nad Labem (collected by KLIKA in 1925).

Fig. 107. Chara rudis in the Czech Republic.

Locations: near Jáchymov (collected by VelenOvskÝ in 1885).

Fig. 116. Chara tomentosa in the Czech Republic.Locations: pond Blato near Poděbrady (collected by OpIz in 1823); Hodonín (collected by DosTÁL in 1944); marsh near Horní Němčí (collected by NovotNÝ in 1972); fish keep near stream Válovický, Pardubice region (collected by SKÁcelovÁ in 1998).

Fig. 126. Chara vulgaris in the Czech Republic.

Locations: Prague (collected by SNOPŘEHLASBL in 1854 and by PolÁK in 1874); Všetaty (collected by ČElakovsKÝ in 1876 and by KLIKA in 1930); near Bělá pod Bezdězem (collected by Hippelli in 1864); near Cihelna (collected by VelenOVSKÝ in 1879); stream near Nymburk (collected by Velenovský in 1881); Všetaty-Přívory (collected by
VelenOvSKÝ in 1881 and by KLIKA in 1923); Nymburk (collected by VelenovskÝ in 1883); near Vrutice, Lysá nad Labem region (collected by VeLENOVSKÝ in 1884 and by ČELAKOVSKÝ in 1888); pond near Velké Čakovice (collected by VeLENOVSKÝ in 1885); near Žatec (collected by ČELAKOVSKÝ in 1886); Páterov near Bělá pod Bezdězem (collected by VILHELM in 1892); Oužice near Kralupy (collected by Tocl in 1895 and by VILHeLm in 1901); Řepov near Mladá Boleslav (collected by VILHeLM in 1898); Rečkov near Bělá pod Bezdězem (collected by VILHELm in 1899); between Šavník and Bukovice (collected by Rohlena in 1901); Chlumec nad Cidlinou (collected by VILHELM in 1901); Kladno (collected by Vilhelm in 1901); Kosořice (collected by Vilhelm in 1901, 1911); pool between Vavřinec and Byšice (collected by VILHELM in 1901); ditch between Vrutice and Zelenice (collected by VILHELM in 1902); between Vavřinec and Zelenice (collected by Vilhelm in 1902); near Velenka (collected by Domin in 1902); salt-meadows Srpina near Bečov (collected by Vilhelm in 1902); stream near Kovaří (collected by VelenovsKÝ in 1902); near Rožd'alovice (collected by Vilhelm in 1909); Brno region (collected by PODPĚRA in 1909); pond Vrabcovský, Čáslav (collected by Novák in 1909); Kosovice (collected by VILHELM in 1911); near Pečice (collected by VILHELM in 1911); pool near Sokolnice (collected by DVOř́́K in 1912); pond Karlický near Dobřichovice (collected by VelenovskÝ in 1913 and by NovÁK in 1921); pond near Turnov (collected by VILHELM in 1913); pond Nečas near Břístev (collected by BAUDYš in 1913); near Lysá nad Labem (VILHELM 1914); pond near Jičín (VILHEM 1914, collected by BAUdY̌̌ in 1911 and by VALOUŠEK in 1925); Teplice (Vilhelm 1914); Turnov (VILHelm 1914); Lovčice (collected by PRÁT in 1915); near Roudnice (collected by NovÁK in 1919); Očelice near Opočno (collected by ROHLENA in 1919); Lysá nad Labem (collected by KLIKA in 1920); stream near Panenský Týnec (collected by Novák in 1920); Vratice near Mělník (collected by VILHELM in 1920 and by KLIKA in 1930); Havlíčkův Brod (collected by STEHLíK in 1921); Jílové Dvory near Kutná Hora (collected by Klášterský in 1921); Nové Dvory near Kutná Hora (collected by KLÁŠTERSKÝ in 1921); Podivín (collected by LƯZA in 1921 and by PODPĚra in 1921); pond near Plavnice (collected by Rohlena in 1921); Prašnice, Uherský Brod region (collected by STEHLíK in 1921); Třebechovice near Hradec Králové (collected by RoHLENA in 1921); Uherský Brod (collected by Stehlík in 1921); near Velká Chuchle, Prague region (collected by VilHeLm in 1922); Bílichov (collected by KLIKA in 1923); Chroustovice near Uhersko (collected by KLIKA in 1923); Kersko near Poříčany (collected by KLIKA in 1924); near Kyjov (collected by BílÝ in 1924); pond Nesyt near Poštorná (collected by BílÝ in 1924); pool near Dubňany, Kyjov region (collected by BílÝ in 1924); Bečov near Bílina (collected by KLIKA in 1925); stream Maxův near Libušín (collected by Domin in 1925); Milotice (collected by Bílý in 1927); lake Čejčské (collected by BílÝ in 1927); saltmeadows Bílý hlíny near Podivín (collected by BílÝ in 1927); Strážnice (collected by PODPĚrA in 1927); Pouzdřany (collected by KLIKA in 1930); ditch near pond Mlýnský, Lednice (collected by ZAPLETÁLEK in 1930); pond Nesyt, Lednice (collected by ZAPLETÁLEK in 1931 and 1932); pond Střední, Lednice (collected by ZAPLETÁLEK in 1931); peat bog Velichovky (collected by Švanda in 1933); Na Kuňkách, Morava region (collected by KLIKA in 1933); near Rakvice (collected by BílÝ in 1938); ditch near Nesvačilka (collected by Bílý in 1938); near sream Dunávka near Opatovice (collected by Bílý in 1938); Velká Ves near Týniště nad Orlicí 
(collected by JIRSÁK in 1938); Sokolnice near Brno (collected by LANG in 1942); pools near Vsetín, Kateřinice (collected by PospíšlL in 1942); near Telnice (collected by BílÝ in 1946); pond Skučák near Rychvald, Bohumín region (collected by ŠMARDA in 1950); pool near Čejč, Terezín region (collected by Šmarda in 1950); pond Nesyt, Lednice (collected by ŠMARDA in 1950); pond Řežabinec near Písek (collected by KOMÁREK \& RŮŽIČCKA in 1958); Bílé Karpaty (LHOTSKÝ \& Rosa 1955); Bílovice (LHOTSKÝ \& Rosa 1955); Brno (LhotskÝ \& Rosa 1955); Čejč (LhotskÝ \& Rosa 1955); Dubňany (Lhotský \& Rosa 1955); Hranice (LHOtskÝ \& Rosa 1955); Kobylí (LHotsKÝ \& Rosa 1955); Lednice (LHotsKÝ \& Rosa 1955); Měnín (Lhotský \& Rosa 1955); Náměšt’ nad Oslavou (LhotskÝ \& Rosa 1955); Nivnice (LHOTSKÝ \& Rosa 1955); Olomouc region (LHOTsкÝ \& Rosa 1955); Opatovice (Lhotský \& Rosa 1955); Opava (LhotskÝ \& Rosa 1955); Ostrovačice near Brno (Lhotský \& Rosa 1955); Pohořelice (LHOtskÝ \& Rosa 1955); Rakvice (LhotskÝ \& Rosa 1955); Rosice near Brno (Lhotský \& Rosa 1955); Sedlec near Mikulov (Lhotský \& Rosa 1955); Senorady (LhotsкÝ \& Rosa 1955); Staré Hradiště (LHOTSKÝ \& Rosa 1955); Újezd near Uherský Brod (LhotskÝ \& Rosa 1955); Vracov near Bzenec (Lhotský \& Rosa 1955); Vyškov (LhotskÝ \& RosA 1955); pond Hlohovec near Nesyt (collected by DAMBSKA in 1958); river Vltava, Prague (collected by Jehlí, StuChLÝ \& VÁŇA in 1960); pool near Litoměřice (collected by KUBÁT in 1963); pool near Oblík, Louny region (collected by KUBÁT in 1966); Klecany near Prague (collected by DĚDEČEK in 1971); near Roztoky (collected by DĚDEČEK in 1972); Písek (collected by DĚDEČEK in 1972); Těšice near Čakovice (collected by DĚDEČEK in 1972); Putim near Písek (collected by DĚDEČEK in 1973); pond Charvátův, sand pit Teletín near Teletín (collected by JIRÁKOVÁ in 1978); Stratov, Nymburk region (collected by JAROSLAV RYDLO in 1984); pool near Dubá, Česká Lípa region (collected by JAROSLAV RYDLO in 1984); sand pit Stratov, Nymburk region (collected by JAROSLAV RYdLO in 1984); Tišice, Mělník region (collected by JAROSLAV RYDLO in 1984); near Orlice, Hradec Králové region (collected by JAROSLAV RYDLO in 1984); near Libouchec, Děčín region (collected by UhLířová in 1984); stream near Samotín, Kladno region (collected by JAROSLAV RYDLO in 1985); near stream Proudnický, Hradist'ko II, Kolín region (collected by JAROSLAV RYDLO in 1985); Roudnice nad Labem (collected by JAROSLAV RYDLO in 1985); Městečko, Křivoklát region (collected by JaRosLaV Rydlo \& KostKovÁ in 1987); Rovesnice II, Kolín region (collected by JAROSLAV RYDLO in 1987); sand pit between Zdětín and Chotěnov, Mladá Boleslav region (collected by JAROSLAV RYDLO in 1987 and 1988); Bílichov, Kladno region (collected by SÁdLo in 1988); dump Albrechtická, Most region (collected by Kostován \& JAROSLAV RYDLO in 1988); pool near pond Lanžhot, Lanžhot, Břeclav region (collected by HusÁK \& JAROSLAV RYDLO in 1988); Kropáčova Vrutice, Mladá Boleslav region (collected by JAROSLAV RYDLO in 1989); pool near Čelákovice (collected by JAROSLAV RYDLO in 1989); pond near Hřebečníky, Křivoklát region (collected by JAROSLAV RYDLO in 1989); Kopidlno, Jičín region (collected by JAROSLAV RYDLO in 1989); pool near river Mrlina, Pševes, Jičín region (collected by JAROSLAV RYDLO in 1989); Hradiště, Znojmo region (collected by JAROSLAV RYDLO in 1992); pond near Červený vrch, Lounské středohoří region (collected by JAROSLAV RYDLO, HAMERSKÝ \& KuBÁtovÁ in 1992); Opolany, Nymburk region (collected by JAROSLAV RYDLO in 1993); mining area near Jenišovice, Mělník region (collected by JAROSLAV RYDLO in 1993); pond Žehuňský, Žehuň (collected by JAROSLAV RYDLO in 1994); pool near Lesná, Znojmo region (collected by JAROSLAV RYDLO in 1994); pond in forest, Brno-Kohoutovice (collected by SUTORÝ in 1994); Vranov nad Dyjí (collected by JAROSLAV RYdLO in 1994 and ReItrová, JAROSLAV RydLO \& JAN RydLO in 2007); near Kostomlaty nad Labem (collected by JAROSLAV RYDLO in 1994 and 2000); Prague, Spořilov (collected by BOHÁČ in 1995); Valašské Klobouky (collected by JAROSLAV RYDLO in 1995); Staré Ždánice, Pardubice region (collected by JAROSLAV RYDLO in 1995); pool Lučina near Radějov, Bílé Karpaty region (collected by JAROSLAV RYDLO in 1995); Kouty, Nymburk region (collected by JaroslaV Rydlo in 1995); Vlkov pod Oškobrhem (collected by JAROSLAV RYDLO in 1995); pond near Lochkov, Prague 5 (collected by HAASOvÁ in 1995); Velké Zboží, Poděbrady region (collected by JAROSLAV RYDLO in 1995); Jiřice, Nymburk region (collected by JAROSLAV Rydlo in 1996); Měňany, Český kras region (collected by JAROSLAV RYdLo in 1997); Dvory, Nymburk region (collected by JAROSLAV RYDLO in 1997); pond in forest, Loučeň, Nymburk region (collected by JAROSLAV RYDLO in 1997); Struhy, Mladá Boleslav region (collected by JAROSLAV RYDLO in 1997); Dvory, Nymburk region (collected by JAROSLAV RYDLO in 1997); Hostětín, Bílé Karpaty region (collected by JaROSLAV RYdLO in 1998); Komňa, Bílé Karpaty region (collected by JAROSLAV RYDLO in 1998); Vápenice, Bílé Karpaty region (collected by JAROSLAV RydLo in 1998); pond between Březová and Nová Bošáca, Bílé Karpaty region (collected by JAROSLAV RYDLO in 1998); sand pit near river Kyjovka, Moravská Nová Ves, Břeclav region (collected by Šumberová in 1998); pools and sand pit, Litovelské Pomoraví region (collected by SKÁCELOvÁ in 1998); dump, settlement tank near pond Kuprovka, Radvanice, Trutnov region (collected by SKÁCELOVÁ in 1998); pond Rokytnický, Rokytnice, Český ráj region (collected by JAROSLAV RYDLO in 1998 and 2007); pond Charvátův, Voznice, Brdy region (collected by JAROSLAV RYDLO in 1999); pond near stream Lipovský, Slavičín, Zlín region (collected by JAROSLAV RYDLO in 1999); Radějov, Bílé Karpaty region (collected by JAROSLAV RYDLO in 1999); Milčice, Nymburk region (collected by JAROSLAV RYDLO in 2000); pool Bejkovna, Lžovice, Kolín region (collected by JAROSLAV RYDLO in 2000); Běleč, Beroun region (collected by JAROSLAV RYDLO in 2001); Kanin, Nymburk region (collected by JAROSLAV RYDLO in 2001); Lžovice, Kolín region (collected by JarosLaV RydLo in 2001); pond Osecký, Kněžice, Nymburk region (collected by Jaroslav Rydlo in 2001); Písková Lhota Nymburk region (collected by JAROSLAV RYdLO in 2001); Chrást, Nymburk region (collected by JAROSLAV RYDLO in 2001); swimming pool, Tatce, Nymburk region (collected by JAROSLAV RYDLO in 2001); Úmyslovice, Nymburk region (collected by JAROSLAV RYDLO in 2001); pond near Budiměřice, Nymburk region (collected by JAROSLAV RYDLO in 2001); pond in Kersko, Nymburk region (collected by JAROSLAV RYDLO in 2001); between Velký Osek and Libice nad Cidlinou, Nymburk region (collected by JAROSLAV RYDLO in 2001); stream near Černíkov, Pardubice region (collected by SAMKovÁ in 2001); dump, Sokolov region (collected by SKÁCELOVÁ in 2001); pond Alah V in forest Boří, Hlohovec, Břeclav region (collected by ŠumBERovÁ in 2001); lake near Vacenovice, Moravia region (collected by SKÁcelová in 2002); pond Olšovský, Loučeň, Nymburk (collected by JAROSLAV RYDLO in 2002); Kanín, Nymburk region (collected by JarosLaV RYdLO in 2002); Mcely, Nymburk region (collected by JAROSLAV RYDLO in 2002); Pasohlávky, Břeclav region (collected by JAROSLAV RYDLO in 2002); fish keep near pond Žabakor, Březina nad Jizerou, Mladá Boleslav region 
(collected by Šumberová in 2002); Milčice, Nymburk region (collected by JAROSLAV RYDLO in 2002); pond near Oškobrh, Nymburk region (collected by JAROSLAV RydLO in 2002); pond Lutovník, Loučeň, Nymburk region (collected by JAROSLAV RYDLO in 2002); Velim, Kolín region (collected by JaROSLAV RYdLo in 2003); sand pit near Vojkovice, Mělník region (collected by JAROSLAV RYDLO in 2003); pond krčínský, Vinice, Nymburk region (collected by JAROSLAV RYDLO in 2003); sand pit near Vliněves, Mělník region (collected by JAROSLAV RYDLO in 2003); pond Dobroměřický, Dobroměřice, Louny region (collected by JAROSLAV RYDLO in 2004); pool in forest, Opolny, Nymburk region (collected by JAROSLAV RYDLO in 2004); pond in forest Žehuňský, Kněžičky, Nymburk region (collected by JAROSLAV RYDLO, HodÁLOVÁ \& MoLíKová in 2004); pond Čihadelský, Chot'ovice, Nymburk region (collected by JAROSLAV RYDLO, HodÁLOVÁ \& MolíKOVÁ in 2004); pond near Stará Hasina, Nymburk region (collected by JaroslaV Rydlo in 2004); pond Horní, Rožd’alovice, Nymburk region (collected by JAROSLAV RYDLO in 2004); Vápensko, Nymburk region (collected by JAROSLAV RYDLO in 2004); pond Dlouhopolský, Dlouhopolsko, Nymburk region (collected by Jaroslav Rydlo in 2004); Opolany, Nymburk region (collected by Jaroslav Rydlo in 2004); pond Písečný near Milotice, Moravia region (collected by SKÁcELOVÁ in 2004); Bakov nad Jizerou (PoulíčKovÁ et al. 2004); Bečov nad Teplou (PoulíčKová et al. 2004); Bělá pod Bezdězem (PoulíčKovÁ et al. 2004); Beroun (PoulíčKovÁ et al. 2004); Bílichov (PoulíčKovÁ et al. 2004); Brandýs nad Orlicí (PoulíčKovÁ et al. 2004); Chlumec near Jičín (PoulíčKovÁ et al. 2004); Čelákovice (PoulíčKovÁ et al. 2004); Děčín (PoulíčKovÁ et al. 2004); Doksy (PoulíčKovÁ et al. 2004); Dymokury (PoulíčKovÁ et al. 2004); Hradec Králové (PoulíčKovÁ et al. 2004); Jabkenice (PoulíčKovÁ et al. 2004); Karlík near Beroun (PoulíčKovÁ et al. 2004); Kopidlno (PoulíčKovÁ et al. 2004); Kostelec nad Orlicí (PoulíčKovÁ et al. 2004); Kostomlaty pod Milešovkou (PoulíčKové et al. 2004); Kralupy nad Vltavou (PoulíčKovÁ et al. 2004); Liblice (PoulíčKová et al. 2004); Litoměřice (PoulíčKovÁ et al. 2004); Lovosice (PoulíčKovÁ et al. 2004); Lysá nad Labem (PoulíčKovÁ et al. 2004); Mladá Boleslav (PoulíčKovÁ et al. 2004); Mělník (PoulíčKovÁ et al. 2004); Neratovice (PoulíčKovÁ et al. 2004); Nové Mlýny (PoulíčKovÁ et al. 2004); Nymburk (PouLíčKovÁ et al. 2004); Opočno (PoulíčKovÁ et al. 2004); Panenský Týnec (PoulíčKovÁ et al. 2004); Pardubice (PoulíčKovÁ et al. 2004); Podolí (PoulíčKová et al. 2004); Polabí (PoulíčKovÁ et al. 2004); Putim (PoulíčKovÁ et al. 2004); Roudnice nad Labem (PoulíčKovÁ et al. 2004); Roztoky (PoulíčKovÁ et al. 2004); Rýznburk (PoulíčKová et al. 2004); Teplice (PoulíčKová et al. 2004); Terezín (PoulíčKovÁ et al. 2004); Třebechovice pod Orebem (PoulíčKovÁ et al. 2004); Týn nad Vltavou (PoulíčKová et al. 2004); Týnec nad Labem (PoulíčKová et al. 2004); Úpice (PoulíčKovÁ et al. 2004); complex of pools near Terezín, Hodonín region (collected by ŠuMBEROVÁ in 2005); Nečichy, České středohoří region (collected by JAROSLAV RYDLO in 2005); pond near Braňany, České středohoří region (collected by JAROSLAV RYDLO in 2005); near pool Benedikt, Most region (collected by JAROSLAV RYDLO in 2005); Vtelno, České středohoří region (collected by JAROSLAV RYdLo in 2005); Vršovka, Náchod region (collected by JAROSLAV RYDLO in 2005); Černčice, Milešovské středohoří region (collected by JAROSLAV RYDLO in 2005); Volevčice, Most region (collected by JAROSLAV RYDLO in 2005); Počevody, Louny region (collected by JAROSLAV RYDLO in 2005); Býchovy, Kolín region (collected by
JAROSLAV RYDLO in 2005); pond Dubový, Loučeň, Nymburk region (collected by JAROSLAV Rydlo \& Molíková in 2005); pond Olšový, Loučeň, Nymburk region (collected by JAROSLAV RYDLO in 2005); pool near left bank of river Bílina, Most (collected by JAROSLAV RYDLO in 2005); PragueŘeporyje (collected by Jaroslav Rydlo HRADEČNÁ, NovÁKOVÁ \& ZÁRYBNICKÁ in 2006); Štěpánov, České středohoří (collected by JAROSLAV RYDLO in 2006); pool near pond Vlašňov, Olbram Kostel (collected by BraVENCOVÁ, ReITER, JAROSLAV RydLO \& JAN RYDLO in 2007); near Žehrov, Český Ráj region (collected by JAROSLAV RYDLO \& VACKOVÁ in 2007); pond Krčský, Městec Králové (collected by JAROSLAV RYdLO \& VydRová in 2007); pond Dolní Čihodolský, Kněžičky, Nymburk region (collected by JAROSLAV RYDLO \& VydROVÁ in 2007); Kořenice, Kolín region (collected by JAROSLAV RYDLO in 2007); reservoir Darkovská near Karviná (collected by ADAMEC in 2007); ditch near Dyje, forest Soutok, Břeclav region (collected by ŠuMBEROVÁ in 2007); Rakšice, Znojmo region (collected by BraVENCOVÁ, ReITER, JAROSLAV RYDLO \& JAN RYDLO in 2007); pond near Točník, Křivoklát region (collected by JAROSLAV RYDLO \& JAN RYDLO in 2007); pool in forest Sánský, Opolany, Nymburk region (collected by Bartošová \& JAROSLAV RYDLO in 2007 and 2008); between Lomnice and Vintírov (collected by HAUER in 2008); Běstvina (collected by KoUTECKÝ in 2008); near swimming pool Barbora near Teplice (collected by HAUER in 2008); pond Borovský, Dokesko region (collected by KoUTECKÝ in 2008); pond near Vřesová (collected by HAUER in 2008); reservoir Dolní Michal, Sokolov region (collected by SkÁcelová in 2008); Řídká Blana, České Budějovice region (collected by VYDROVÁ in 2008); pond near Tulešice, Znojmo region (collected by BARTOŠOVÁ, JAROSLAV RYDLO \& JAN RYDLO in 2008); fish keep near pond Písečný and Lužický, Hodonín region (collected by ŠuMBEROVÁ in 2008); pond Hlohovec, Hlohovec, Břeclav region (collected by ŠumBERovÁ in 2008); pool Komínová in forest Boří, Břeclav-Poštorná (collected by Šumberová in 2008); Hustopeče nad Bečvou (collected by BARTOŠOVÁ \& JAROSLAV RYDLO in 2008).

Fig. 134. Nitella batrachosperma in the Czech Republic. Locations: Doksy region (collected by VILHELM in 1913); České Budějovice region (VILHELm 1914); Neratovice (collected by LưZa in 1920); Moravská Třebová (collected by SтенLí in 1921); near Hradec Králové (collected by Rohlena in 1921); Prague (collected by PodPĚra in 1921); Brno (Lhotský \& Rosa 1955); near Brno (LhotskÝ \& Rosa 1955); Valtice (LhotskÝ \& Rosa 1955); near Třeboň (collected by JIŘi KOMÁreK in 1987).

Fig. 142. Nitella capillaris in the Czech Republic. Locations: pool near Všetaty (collected by ČELAKOVSKÝ in 1876); Doksy (collected by ČELAKOVSKÝ in 1882); Kostomlaty near Nymburk (collected by VelenOvSKÝ in 1885); near Ústí nad Labem (collected by RoHLENA in 1921); Chrastava, Liberec region (collected by VILHELM in 1922); between Neratovice and Brandýs nad Labem (collected by KLIKA in 1923); Plzeň (collected by KLIKA in 1923); near Prague (collected by KLIKA in 1930); pond Heřmanovský, Bohumín region (collected by ŠMARDA in 1950); pond Skučák near Rychvald, Bohumín region (collected by ŠMARDA in 1950); near Chlum near Třeboň (PoulíčKovÁ et al. 2004); near Nadějov (PoulíčKovÁ et al. 2004).

Fig. 151. Nitella flexilis in the Czech Republic.

Locations: near Štiřín (collected by BERCHTOLD in 1823); 
Liberec (collected by LANGER in 1845); Prague (collected by OpIZ in 1849,1852 , by LeONHARDI in 1852 and by ScHÖBL in 1854); Šluknov near Fugava (collected by KARL in 1849); Česká Kamenice (collected by Hrabal in 1854); near Chomutov (collected by KNAF in 1855); near Prague (collected by Kalmus in 1854); Kutná Hora (collected by PeYl in 1862); Př́braz near Stráže (collected by LeONHARdi in 1861, 1863); near Podmokly (collected by TEMPSKÝ in 1863); Stráž (collected by LEONHARDI in 1863); Bosyně (collected by REICHARDT in 1864); Struhařov (collected by ČELAKOVSKÝ in 1875); pond Žindavský, Nepomuk (collected by ČELAKOVsKÝ in 1876); pool near Všetaty (collected by ČELAKOVSKÝ in 1876); Třeboň (collected by ViLHelm in 1899); pond Proudný, ditch near Branná, Třeboň region (collected by VILHELM in 1899); ditch between Třeboň and Hové Hrady (collected by ViLHELm in 1899); streams near Strašnice, Prague (collected by VelenovskÝ in 1902); near Bečov, Rudohoří region (collected by DvoŘÁK in 1912); Třebíč (collected by Dvoř́́K in 1914); Lutová near Třeboň (VILHelm 1914); near Český Krumlov (VILHeLm 1914); stream Chvalšinský near Český Krumlov (VILHELM 1914); Vodňany (collected by ŠTĚPÁN in 1922); Doksy (collected by VILHELM in 1923 and by Novák in 1927); Stromovka (collected by OPIZ in 1823); Mariánské Lázně (collected by OpIz in 1823); pond, Jevany, Prague region (collected by NĚMEC in 1923 and by OPIZ in 1825 ); river Vltava near Čertova stěna, Bohemia forest region (collected by DĚDEČEK in 1938); pools near Roztoky (collected by DĚDEČEK in 1939); pool near Ruprechtice, Broumov region (collected by SoučKOvÁ in 1947); ditch near Jersín (collected by ŠMARDA in 1950); ditch near Hustopeče (collected by ŠMARDA in 1950); Dobrá Voda, Třebíč region (LHOTsKÝ \& Rosa 1955); Hranice (LHOTsKÝ \& Rosa 1955); Javornice (LHOTSKÝ \& Rosa 1955); Jeseníky (LHOTSKÝ \& Rosa 1955); Jindřichovice (LнотsкÝ \& Rosa 1955); Kralice (Lhotský \& Rosa 1955); Kyjovice (LHOtskÝ \& Rosa 1955); Náměšt' nad Oslavou (LhotskÝ \& Rosa 1955); Ocmanice (LhotskÝ \& Rosa 1955); Okrašovice (LhotsKÝ \& Rosa 1955); Olomouc region (LHOTSKÝ \& Rosa 1955); Ptáčov (LhotskÝ \& Rosa 1955); Skryje (LhotskÝ \& Rosa 1955); Svitavy (LHOtsкÝ \& Rosa 1955); Stareč (LHotskÝ \& Rosa 1955); Telč (Lhotský \& Rosa 1955); Zňátky (LhotskÝ \& Rosa 1955); pond Radov near Blatná (collected by DĄMBSKA in 1958); Sumperk (collected by LENEČEK in 1974); stream Keblanský, Lánská Obora near Nový Dvůr, Křivoklát region (collected by JAROSLAV RYDLo in 1989); pond Velké Dářko, Žd'árská vrchy (collected by RYDLO in 1991); river Jihlava, Mohelno, Třebíč region (collected by SuTORÝ in 1992); river Vltava, Prague-Braník (collected by JAROSLAV RYDLO in 1993); Trhové Sviny region (collected by VydROVÁ in 1994); pool near river Cidlina, Libice nad Cidlinou (collected by JAROSLAV RYDLO in 1995); Aš region (collected by JAROSLAV RYDLO in 1996); Nebákov pond, Český ráj (collected by Jaroslav Rydlo \& Vacková in 1997); pond Horní, Voznice, Brdy region (collected by JAROSLAV RYDLO in 1999); Nová Bystřice region (collected by SKÁCELOVÁ in 2000); pond near Vyklantice, Pelhřimov region (collected by ČECH in 2002); small pond near pond Hradecký, Jabkenice, Mladá Boleslav region (collected by JAROSLAV RYDLO in 2002); pool near Dobrá, Bohemia Forest region (collected by BufKovÁ \& JARosLAV RYdLO in 2004); near Želnava, Bohemia Forest region (collected by BuFKovÁ \& JAROSLAV RYDLO in 2004); Studánka, Cheb region (collected by JAROSLAV RYDLO in 2004); Záhrozdí, Šumava region (collected by BufKovÁ \& JARoslav RydLo in 2004); Buková near Př́ibram (collected by JAROSLAV RYDLO in 2004); pond Voborníček, Břístev, Nymburk region (collected by JAROSLAV RYDLO in 2004); Bečov nad Teplou (PoulíčKovÁ et al. 2004); Běchovice (PoulíčKovÁ et al. 2004); Havlíčkův Brod (PoulíčKovÁ et al. 2004); Jablonec nad Nisou (PoulíčKová et al. 2004); Lužnice (PoulíčKová et al. 2004); Podmokly (PoulíčKová et al. 2004); Stráž nad Nežárkou (PoulíčKová et al. 2004); pond Vojenský near Lukov, Milešovké Středohoří (collected by JAROSLAV RYDLO in 2005); pond near Krásňany, Cheb region (collected by JAROSLAV RYDLO in 2005); pool near Černíč, Českomoravská vrchovina (collected by ČECH in 2005); near pond Podliščí, Počátky, Českomoravská vrchovina (collected by EKRTOvá in 2006); reservoir Nýrsko (collected by JAROSLAV RYDLO in 2006); Matenský pond near Jindřichův Hradec (collected by KoŠNAR in 2007); Horní Lesák pond, Jindřichův Hradec region (collected by HESOUN \& HUSÁK in 2007); pool near Magdalena, Třeboň region (collected by DvoŘÁKovÁ in 2007); Podlesí, Orlické mountains (collected by JAROSLAV RYdLO \& VydrovÁ in 2007); pond near Sedmihorky, Český Ráj (collected by JAN RYdLO \& JAROSLAV RYdLO in 2007); pond Dolní, Podbořánky, Rakovník region (collected by MolíkovÁ, JAROSLAV RydLo \& ŠAŠEK in 2007); pond Plaviště, Soseň, Rakovník region (collected by MoLíkOVÁ, JAROSLAV RYDLO \& ŠAŠEK in 2007); Blešno, Hradec Králové region (collected by JAN RYDLO \& JAROSLAV RYDLO in 2007); Ďáblík near Trhové Sviny (collected by VydrovÁ in 2008); Kř́žžová Lhota, Vlašim region (collected by KREMLOVÁ in 2008); Malé Chrastí near Třebíčko (collected by Vydrová in 2008); near pond Mladovický, near pond Žehovák near Velíš, Vlašim region (collected by KREMLOVÁ in 2008); NP Podlesí, Vlašim region (collected by KremLovÁ in 2008); Podstrání near Krásno (collected by HAUER in 2008); pond between Suchdol and Halámky (collected by VYDROVÁ in 2008); pond near Milovanice, Vlašim region (collected by KREMLOVÁ in 2008); pond Pazourkův, Strmilov (collected by VYDROVÁ in 2008); Radostín, Žd'ár nad Sázavou region (collected by KOŠNAR in 2008); Vlašim region (collected by KREMLOVÁ in 2008); Zliv (collected by Vydrová in 2008); near V Poli, Frýdlant, Černovousy region (collectd by MORÁvKOVÁ \& Jaroslav Rydlo in 2008); pond Nebákov, Roveň, Český Ráj region (collected by JAN RYDLO \& JAROSLAV RYDLO in 2008); Tichá, Český Krumlov region (collected by JAROSLAV RYdLO \& VydRovÁ in 2008); pond Horní Kracle, Ruda, Křivoklátsko region (collected by JAN RYDLO \& JAROSLAV RYDLO in 2008); pond Hut'ský, Žofín (collected by JAROSLAV RYdLO \& VydrovÁ in 2008); near Soumarský Most, Bohemia Forest region (collected by BARTOŠOVÁ \& JAROSLAV RYDLO in 2008); pool near Lhota u Kestřan, Písek region (collected by GRULICH \& VYdROVÁ in 2008); pond near strem Keblanský, Keblany, České Budějovice region (collected by VYDROVÁ in 2008); Hrdlořezy, Jindřichův Hradec region (collected by VyDROVÁ in 2008); pool no 109-110 in forest Rídká Blana, České Budějovice region (collected by GRULICH \& VYDROVÁ in 2008); pond Pazourák, Malý Jeníkov, Jindřichův Hradec region (collected by GRULICH \& VYDROVÁ in 2008); pond Blanko (collected by SKÁcelová in 2008); mind Jiř́ Pinka Sokolov region (collected by SKÁCELOVÁ in 2008); pond no 1 near Božičany, Sokolov region (collected by SKÁcelová in 2008); forest pond Ivaniny, Proseč pod Křemešníkem, Pelhřimov region (collected by С̆ stream Bohužský, Světlá nad Sázavou (collected by JosEF KOMÁREK in 2008).

Fig. 159. Nitella gracilis in the Czech Republic.

Locations: Nový Valdek (collected by KARL in 1848); near Třeboň (collected by LeONHARDI in 1850 and by VILHELM 
in 1899); Česká Kamenice (collected by Hrabal in 1853); Stráž (collected by LEONHARDI in 1855, 1861, 1863); Liberec (collected by SiEGMUND in 1859); Platy (collected by LEONHARDI in 1862); forest Královský, northern part of the Czech Republic (collected by KarL in 1862); near České Budějovice (collected by LeONHARDI in 1863); near Plzeň (collected by Hora in 1882); near Doksy (collected by VILHelm in 1901); Zlatá Koruna (VILHelm 1914); Mariánské Lázně (collected by OpIz in 1823); Stromovka (collected by OPIZ in 1823); pond Záblatský near Lomnice, Brno region (collected by DąmBSKa in 1958); Děčín (PoulíčKová et al. 2004); Doksy (PoulíčKovÁ et al. 2004); Šumava region (PoulíčKovÁ et al. 2004); Třeboň (PoulíčKovÁ et al. 2004).

Fig. 169. Nitella mucronata in the Czech Republic.

Locations: near Prague (collected by LeONHARDI in 1850 and 1853); Královská Obora near Prague (VILhelm 1914); ditch near Mohelno (collected by DVoř́á in 1919); Olomouc region (LHotský \& Rosa 1955); Nový Valdek (Lhotský \& Rosa 1955); Svitavy (Lhotský \& Rosa 1955); Brno (collected by DAMBSKA in 1958); Velký Osek (collected by RYDLO in 1990); Kluk, Nymburk region (collected by RYDLO in 2000); forest Boří les (HusÁK 2001); Boletice (GRULICH \& VydRovÁ 2006); Velká Ohrazenice (CAISOVÁ et al. 2008).

Fig. 177. Nitella opaca in the Czech Republic.

Locations: near Kamenice (collected by SÝKORA in 1817); Předboj (collected by Leonhardi in 1863); Nové Benátky (collected by DĚDEČEK in 1872); Pazderna near Písek (collected by DĚDEČEK in 1872); Roztoky near Prague (collected by DĚDEČEK in 1872 and 1939); Čechtice near Královice (collected by DĚDEČEK in 1875); Lysá nad Labem (collected by DĚDEČEK in 1876); Nepomuk (collected by ČELAKOVSKÝ in 1876); near Rakovník (collected by HolbaCH in 1877); Čekanice (collected by VelenovskÝ in 1878 and 1888); Čertova Stěna, Šumava region (collected by DĚDEČEK in 1878); Opočno (collected by ČELAKOVSKÝ in 1880); near Mariánské Lázně (collected by KRÁTKÝ in 1883); Čečelice (collected by VelenOvsKÝ in 1885); Stará Lysá (collected by VeLENOVSKÝ in 1885); near Lysá nad Labem (collected by VelenOVsKÝ in 1885 and by DĚDEČEK in 1937); Kostomlaty, Nymburk region (collected by VeLENOVSKÝ in 1887); Třeboň (collected by VILHELM in 1899); Všetaty (collected by VILHELM in 1899); pool in Jeníčkova Lhota near Tábor (collected by RAVBA in 1900); Jeníčková Lhota near Tábor (collected by RADBA in 1900); Rožd'alovice (collected by SASKA in 1901); pools between Byšice and Všetaty (collected by VILHELm in 1901); Všetaty near Vavřinec (collected by VILHELM in 1901); between Jestřebí and Podhrází, Doksy region (collected by VILHELM in 1902); between Mělnická Vrut' and Jelenice near Mělník (collected by VILHELM in 1902); near Čelákovice (collected by VILHELM in 1902); between Doksy and Jestřebí (collected by VILHeLM in 1902); ditch between Vrutice and Zelenice (collected by VILHELM in 1902); streams near Strašnice (collected by VelENOVSKÝ in 1902); Jičín (collected by BAUDYš in 1911); Krč, Prague region (VILHelm 1914); pond Pařez near Zámostí (collected by BAUDYš in 1918); Vodňany (collected by ŠTĚPÁN in 1921 and 1922); pool near Jizera, Nové Benátky (collected by Dědeček in 1923); Brzovany near Louny (collected by KLIKA in 1926); near Prague (collected by VILHELM in 1928); river Vltava near Čertova stěna, Bohemia forest region (collected by DĚDEČEK in 1938); pond in valley Josefov, Blansko region (collected by ČERNOCH in 1949); pool near Čejč, Terezín region (collected by ŠMARDA in 1950); Náměšt’ nad Oslavou (LHOTSKÝ \&
Rosa 1955); Ocmanice (LHOTSKÝ \& Rosa 1955); Pozd’atín (LhotskÝ \& Rosa 1955); Křivoklát (PoulíčKovÁ et al. 2004); Písek (PoulíčKová et al. 2004); Prague (PoulíčKová et al. 2004); Putim (PoulíčKovÁ et al. 2004); pond Podoborský near Nové Hrady (collected by ŠuMBERová in 2007).

Fig. 187. Nitella syncarpa in the Czech Republic.

Locations: Kamenice (collected by SÝKORA in 1818); Karlovy Vary (collected by Reuss in 1839); Nové Dvory near Kutná Hora (collected by PEYL in 1857); Třeboň (collected by LeONhardi in 1863); Prague (collected by Velenovský in 1887); pond Tisý near Lomnice nad Lužnicí (collected by VILHELM in 1899 and 1910); Sychrov (collected by VILHELM in 1913); Voňany (collected by ŠTĚPÁN in 1922); Jihlava (LhotskÝ \& Rosa 1955); Stonařov (LhOtskÝ \& Rosa 1955); pond near Blatná (collected by DĄMBSKA in 1958); pools near pond Kupcov, Blatná (collected by DĄMBSKA in 1958); pond Pražák near Vodňany (collected by DĄMBSKa in 1962); Turnov (PoulíčKovÁ et al. 2004); Vodňany (PoulíčKovÁ et al. 2004); fishpond Ptačí Blato near Třeboň (collected by ADAMEC in 2008).

Fig. 195. Nitella tenuissima in the Czech Republic. Locations: near Milevsko (collected by DĚDEČEK in 1875); near Chotěboř (collected by RoHLENA in 1921); pool near pond Kupcov, Blatná (collected by DĄMBSKA in 1958).

Fig. 205. Nitellopsis obtusa in the Czech Republic. Locations: near Hlinsko (collected by DostÁL in 1941); pool near Malše, Třeboň region (collected by DĚDEČEK in 1938).

Fig. 217. Tolypella glomerata in the Czech Republic. Locations: near Netřeby, Neratovice region (collected by ČELAKOVSKÝ in 1876); pond Skučák near Rychvald, Bohumín region (collected by ŠMARDA in 1950); Lednice (LHOTSKÝ \& Rosa 1955); Valtice (LHOTSKÝ \& Rosa 1955); small pond near pond Dolní Candát, Ostrov, Karlovy Vary region (collected by JAROSLAV RYDLO in 1989); stream Chebský between Chleby nad Draho, Nymburk region (collected by JAROSLAV RYDLO in 1990); near pond Hrůdka, Rokytnice, Český ráj (collected by JAN RYDLO \& JAROSLAV RYDLO in 2008).

Fig. 224. Tolypella intricata in the Czech Republic,. Locations: near Žd'ár nad Sázavou (collected by HoRA in 1882); streams near Strašnice, Prague (collected by VelENOVSKÝ in 1902); pool near river Cidlina, Libice nad Cidlinou (collected by JaroslaV RYdLo in 1996); Kamilov, Nymburk region (collected by JAROSLAV RYDLO in 2001); pond near Žehrov, Český ráj (collected by JarosLAV RYDLO \& VACKOVÁ in 2007).

Fig. 231. Tolypella prolifera in the Czech Republic. Locations: Měnín (LHotsKÝ \& RosA 1955).

(C) Czech Phycological Society

Received December 31, 2008

Accepted February 20, 2009 